\title{
POSTAL SAVINGS
}

WTWIN WALTER KEMMERER 

- 


\section{Digitized by the Internet Archive}

in 2007 with funding from Microsoft Corporation 


\section{POSTAL SAVINGS}

AN HISTORICAL AND CRITICAL STUDY OF THE POSTAL SAVINGS BANK SYSTEM OF THE UNITED STATES

\section{BY \\ EDWIN W. KEMMERER}

PROFESSOR OF ECONOMICS AND FINANCE

PRINCETON UNIVERSITY

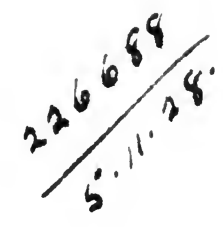

PRINCETON UNIVERSITY PRESS

PRINCETON

LONDON : HUMPHREY MILFORD

OXFORD UNIVERSITY PRESS

I9I7 
Copyright, 1917, by

Princeton University Pregs

Published October, 1917

Printed in the United States of America

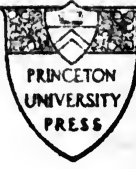




\section{PREFATORY NO'TE}

The financial uncertainties growing out of the European War, the widespread thrift campaign which has been undertaken under the pressure of war conditions, and the resulting great increase in the public's patronage of the postal savings banks have given rise to an unusual public interest in our American postal savings system. This unusual public interest and the fact that there exists nowhere a comprehensive account of the development and present day workings of our American postal savings system furnish the excuse for this volume.

The material here presented is to a substantial extent a revision and integration of material contained in two magazine articles previously published by the author. It is used here with the consent of the magazines' publishers, for which grateful acknowledgment is made. The articles were: "The United States Postal Savings Bank," published in the Political Science Quarterly, volume XXVI (1911); and "Six Years of Postal Savings in the United States," published in the American Economic Review, volume VII (1917). 
In the collection of material the author has made numerous calls upon the officials of the Postal Savings Division of the Post Office Department at Washington, and wishes here to express his gratitude for the generous and courteous assistance which these officials have given by furnishing information from their unusually well kept records. In this connection the author wishes particularly to express his gratitude to Third Assistant Postmaster-General Alexander M. Dockery; Director of Postal Savings Carter B. Keene; and Assistant Director of Postal Savings Charles H. Fullaway. To his colleague, Professor Neil Carothers, the author is greatly indebted for the laborious work of preparing the table of contents and the index and for valuable assistance in connection with the reading of proof.

Princeton University, July 6, 1917. 


\section{CONTEN'TS}

\section{CHAPTER I}

The Movement for Establishment of a Postal Savings System in the United States . . . . .

Long duration of the movement, 1-2. - Movement $1-20$ encouraged by panic of 1907, 2-4. - Declarations of political party platforms in 1908, 4-6. - Debate over desirability of postal savings, 6-7. - Question of the adequacy of existing savings facilities, 7-8. - Statistics relating to existing facilities, 8-10. - Comparison of postal facilities and banking facilities, 11-12. Fear of competition with existing banks, 12-13. Opposition of bankers, 13-15. - Argument against the fear of competition, 15-16. - Losses to depositors from bank failures, 17-19. - Postal savings as a means to attract money from hoarding, 19-20.

\section{CHAPTER II}

The Postal Savings Bank Act of 1910

Classification of provisions, 21. - Administration by a Board of Trustees with discretionary powers, 21-24. - Provisions for deposits, 24-25. - Provisions for withdrawal of deposits, 25-26. - Reserves against deposits, 26-28. - Centralization of administration, 28-30. - The form of credit given to depositors, 30-31. - Method of determining the rate of interest paid depositors, 31-32. - Selection of a two per cent rate, 32-34. - Question of investment of savings funds, 35-37. - Debate in Senate on constitutionality of the bill, 37-40. - Amendment of bill in Senate to insure constitutionality, 40-42. - Final provisions for investment, 42-45. - Privilege of bond investment granted to depositors, 45-46. - Merits of this provision, 46-48. - Investment provisions in relation to outstanding government bonds, 48-49. 


\section{CHAPTER III}

PAGES

Administrative Organization and Selection of Post Offices for Postal Savings Banks . . • . Administrative powers of Board of Trustees changed in 1911, 50. - Administrative machinery reorganized in 1913, 51-52. - Selection of depository post offices, 53. - Negligible volume of business in many postal savings offices, 53-55.

\section{CHAPTER IV}

Depositors and Deposits

Depositor's credit in the form of a certificate, 5657. - Nativity of depositors, 57-60. - Reasons for disproportionate patronage by foreign born, 60-62. - Age grouping of depositors, 62-65. - Negro depositors, 65-66. - Geographical distribution of depositors and deposits: Statistical tables and maps, 66-70. - Distribution of deposits by States, 70-72. Distribution by cities, 72-73. - Average individual deposits, 73-75. - Sources of funds deposited: System has not competed with banks, 75-79. - Fear that system would encourage "runs" on banks in panic periods, 80-82. - Minor instances indicate little danger from this source, 82-84.-Deposits of enemy aliens not affected by war, 84-85. - Limitations on size of deposits and balances onerous, 85-86. - Bill to lighten restrictions vetoed, 86-87. - Arguments in favor of freedom in size of deposits, 87-91. Arguments in favor of restrictions, 91-95. - Limitations partly removed by increase of maximum deposit and balance permitted: Operation of amended provisions, 95-98. - Growth of deposits, 98-99. Interest on deposits not compounded, 99-100. - Injustice of rule preventing interest payments on deposits left shorter time than one year, 100-105.

\section{CHAPTER V}

Investment of Postal Savings Funds

Provisions of original law relating to investment 
and reserve, 106-107. - Provision for investment in United States securities amended in 1916, 107-109. Deposit of savings funds in banks: Qualifications for depository banks, 109-111. - Decline in number of depository banks, 111-113. - State banks as depository banks, 113-116. - Postmasters' "emergency credits" in original law: Abolished in 1913, 116-119. - Out of town depository banks, 119-120. - Collateral security for savings funds deposits: Regulations of the Board of Trustees as to collateral, 120-124. - Rate of interest paid by depository banks: Profits realized by the banks, 124-126. Postal savings bonds, 126-127.

\section{CHAPTER VI}

Conclusios
Postal savings system of real value, $128 .-\dot{\text { Under- }}$ lying philosophy of present decentralized system of depository banks, 128-130. - Should postal savings funds be deposited largely in commercial banks?, 130-131.

\section{APPENDIX A}

The United States Postal Savings Act and its Amendments $\quad \cdot \quad \cdot \quad \cdot \quad \cdot \cdot \cdot \cdot \cdot \cdot \cdot$

Act of June 25, 1910, 133-143. - Amendment of August 24, 1912, 143-144. - Amendment of January 21, 1914, 144-146. - Amendment of September 23, 1914, 146-147. - Amendment of May 18, 1916, 147-150.

\section{APPENDIX B}

No. 1. The Philippine Pogtal Satings Bank Act, as Amended to Juny 1, 1917 . · · · • Act of May 24, 1906, with subsequent amendments, 151-167.

No. 2. Ax Act Authorizing the Postal Savings Bank Investment Board to Make Loans from Funds 
viii

\section{CONTENTS}

Avallable for Investarent to Provinces of the

PAGES

Philippine Islands, Under Guarantee of the

Insular Govern Ment

168-169

Act of May 3, 1907, 168-169.

General Index • • . • . • • • • 171-176 


\section{POSTAL SAVINGS}

\section{CHAPTER I}

The Movement For Establishment of a Postal Savings System in the United STATES

On June 25, 1910, the bill creating the United States postal savings system was signed by President Taft. 'Thus after nearly forty years of discussion, occasionally rising to heights of agitation, as during the administrations of Postmasters-General Creswell, Wanamaker and Meyer; after eight Postmasters-General had recommended the establishment of postal savings banks ${ }^{1}$ and ten times as many bills had been introduced into Congress for this purpose, ${ }^{2}$ the United States found itself in line with most of

1 The recommendations of Postmasters-General from 1871 to the present time, together with other valuable material illustrating the movement for postal savings banks in the United States, are summarized in a speech in the House of Representatives by George Edmond Foss of Massachusetts. Cong. Rec., June 20, 1910, pp. 8709 et seq.

2 For a list of bills, see Report No. 1445, H. R., 61 Cong., 2 Sess. (June 7, 1910), pp. 63-66. 
the other great nations of the world in this matter. ${ }^{3}$ This is not, however, the first experience of the United States with postal savings banks. To be exact, this is the third postal savings bank to exist under the American flag; the first being the Hawaiian postal savings bank, which was established in $\mathbf{1 8 8 6}$ and was closed shortly after the American annexation in 1898, and the second being the Philippine postal savings bank, which has been in successful operation since $1906 .{ }^{4}$

A study of the forty years of discussion which culminated in the establishment of a postal savings system in the United States does not fall within the scope of this book, which is primarily concerned with the system created by the legislation of 1910. It will be desirable to consider only the events immediately leading to that legislation.

Movement for Postal Savings Encouraged by Panic of 1907

The panic of 1907 was characterized by a general lack of confidence in banking institutions.

${ }^{8}$ For descriptions of the different postal savings banks of the world, see Notes on the Postal Savings Banks Systems of the Leading Countries, National Monetary Commission Report, Sen. Doc. No. 658, 61 Cong., 3 Sess.

${ }^{4}$ The Philippine Postal Savings act, as amended to date, together with the principal regulations issued thereunder, will be found in Appendix B, pp. 151-169. 
"Everywhere the banks suddenly found themselves confronted with demands for money by frightened depositors; everywhere, also, banks manifested a lack of confidence in each other." There was a widespread belief among the people, a belief based on sad experience in previous financial panics, that it would be difficult to secure cash during periods of economic disturbance.

Add to the hardships of this panic the numerous recent scandals in "high finance," particularly those connected with New York banks, and it is not surprising that among certain classes in the country a lack of confidence in banking institutions should have been manifested. This distrust of banks led to the propaganda for the guaranty of bank deposits and to a renewal of the agitation for postal savings banks. PostmasterGeneral Cortelyou, in his annual report for $1906,{ }^{6}$ had merely mentioned postal savings banks in connection with other projects, "the merits and defects ... of which should have in the not distant future the fullest consideration." In the three succeeding annual reports the Postmaster-General strongly urged the establishment of postal savings banks. Before the panic of

${ }^{5}$ O. M. W. Sprague, History of Crises under the National Banking System, National Monetary Commission Report, Sen. Doc. No. 538, 61 Cong., 2 Sess., pp. 259-260.

${ }^{6}$ Report of the Postmaster-General, 1906, p. 81. 
1907 was over, and while currency was still at a premium in New York, the newly created State of Oklahoma passed a law, December 17, 1907, providing for the guaranty of bank deposits; and in the course of the next two years four other States, Kansas, Nebraska, South Dakota and Texas, passed deposit guaranty acts. ${ }^{7}$ President Roosevelt in his Messages of December, 1907, and March, 1908, favored a postal savings bank system. ${ }^{8}$ In June, 1908, the Republican national convention included in its platform a plank favoring "the establishment of a postal savings bank system for the convenience of the people and the encouragement of thrift." The Democratic platform, adopted a few weeks later at Denver, after expressing a desire for government guaranty of bank deposits, said: "We favor a postal savings bank if the guaranteed bank cannot be secured, and that it be constituted so as to keep the deposited money in the communities where it is established. But we condemn the policy of the Republican Party in proposing postal savings banks under a plan of conduct by which they will aggregate the deposits

${ }^{7}$ Cf. Thornton Cooke, Insurance of Bank Deposits in the West, in Quarterly Journal of Economics, XXIV, pp. 85108, and XXV, pp. 327-390.

${ }^{8}$ Cong. Rec., Dec. 3, 1907, p. 77, and Mar. 25, 1908, p. 3854 . 
of rural communities and redeposit the same while under government charge in the banks of Wall Street, thus depleting the circulating medium of the producing regions and unjustly favoring the speculative markets." The Prohibition Party platform advocated "the establishment of postal savings banks and the guaranty of deposits in banks"; the Populist platform demanded "that postal savings banks be instituted for the savings of the people"; and the Independence League platform declared, "Government postal savings banks should be established where the people's deposits will be secure, the money to be loaned to the people in the locality of the several banks at a rate of interest to be fixed by the Government." With such unanimity of opinion in all the political parties, the question of postal savings banks did not figure prominently in the campaign. There was, however, considerable discussion of the proposal for guaranteeing bank deposits.

After the election some of the leaders of the Republican party, particularly President Taft, who had for years been a believer in postal savings banks, ${ }^{9}$ began to urge upon Congress com-

${ }^{9}$ It was by the direction of Mr. Taft, when he was Governor of the Philippines, that the author drafted the bill which became the Philippine Postal Savings Bank act of 1906. 
pliance with the Republican platform pledge to establish a postal savings bank system, and the subject received the attention of the Sixty-first Congress, in its second session.

Before considering, however, the legislative history of the so-called Carter bill (named after its sponsor in the Senate, Thomas H. Carter of Montana), which eventually became law, it will be well to review the chief arguments advanced for and against the general proposition to establish in the United States a postal savings system of any kind.

\section{The Debate Over the Desirability of a Postal Savings System}

In spite of the numerous differences in the postal savings bank systems of the forty-odd countries possessing them, there are certain fundamental features common to all. Whatever else a postal savings bank may be, it is invariably an institution working through the post offices, with the primary object of encouraging thrift among the poorer classes by providing safe and convenient places for the deposit of savings at a comparatively low rate of interest. In the discussions of the postal savings bank proposition in this country no one questioned the desirability of encouraging habits of economy and thrift on 
the part of the public, nor was there any question that adequate savings bank facilities should be provided for this purpose. 'The debate hinged very largely upon the question whether adequate savings facilities were not already provided by private initiative.

Question of the Adequacy of Existing Savings Facilities Offered by Banks

The advocates of a postal savings bank claimed that adequate savings facilities were not being provided by private enterprise, and could not be so provided, because of the expense of operating savings banks in small communities, and also in larger ones where the people were not yet educated to the saving habit; and they pointed particularly to the lack of savings facilities in the Southern and Western States.

Postmaster-General George von L. Meyer in his report for $1908^{10}$ cited figures from the Comptroller of the Currency, showing that the deposits in savings banks in the United States at that time amounted to $\$ 3,660,553,945$; that 72 per cent of this amount belonged to the New England States and New York; and that 98.4 per cent belonged to fourteen States, leaving only $\mathbf{1 . 6}$ per cent to the remaining States and all

${ }^{10}$ Pp. 12-13. 
the Territories. These figures were severely criticized by the banking fraternity on the ground that they referred only to mutual and stock savings banks, whereas the savings deposits of the country included also amounts deposited in the savings departments of other kinds of banks. A report was prepared for the Committee on Postal Savings Banks of the Savings Bank Section of the American Bankers Association, under date of May 3, 1909, criticizing the official statistics and offering supplementary figures showing that the savings of the American people amounted to about nine and a half billion dollars, exclusive of deposits in school savings banks, "private investments of small savings in bonds" and "the savings invested in homes and homesteads." The bankers' figures included the accumulations of building and loan associations $(\$ 745,993,000)$ and the assets of life insurance companies (\$3,$159,581,000)$. Obviously the term "savings" is very elastic, and when it is carried beyond the field of small and relatively permanent deposits in banking institutions, and into the field of investments, it is given an extension difficult to limit and of little use in a study of savings bank facilities.

In December, 1909, the National Monetary Commission published its special report giving 
the banking statistics of the country as of $1909 .{ }^{11}$ It estimated the number of banks and banking firms in the United States at 25,000. "Of this number reports were obtained from all but about 2,500, the omissions being chiefly of concerns whose business is confined to brokerage and exchange," ${ }^{12}$ and which would be negligible as savings depositories. Exactly what proportion of the reporting banks carried savings accounts is not known, as some of them did not reply to that part of the inquiry referring to this subject. The figures given, however, showed that of the 6,585 national banks (excluding island possessions and Alaska), 3,511 reported savings accounts, with a total of 1,964,223 savings depositors and savings deposits of $\$ 756,827,891 .^{13}$ Of the 8,239 State banks reporting, 4,675 reported savings accounts, with a total of 2,195,727 savings depositors and savings deposits amounting to $\$ 592,949,131 .^{14}$ Six hundred and twenty-seven mutual savings banks reported 7,204,579 depositors with total deposits of $\$ 3,138,763,705 ; ;^{15} 913$ stock savings banks reported 1,412,634 savings depositors with total deposits of $\$ 495,178,368$. Of 993 private

${ }^{11}$ Sen. Doc., No. 225, 61 Cong., 2 Sess.

12 Ibid., p. 3.

${ }^{13}$ Ibid., pp. 36-39.

14 Ibid., pp. 40-43.

${ }^{15}$ Ibid., p. 44. 
banks, 560 reported having savings accounts with 130,865 savings depositors and total savings deposits of $\$ 32,444,593$, of which approximately half were in the form of certificates of deposit or time deposits. ${ }^{16}$ Of the 862 loan and trust companies reporting, 696 carried savings accounts with 1,965,333 savings depositors and total savings deposits of $\$ 657,697,417 .{ }^{17}$ Grouping all of these kinds of banks together we have 18,219 banks making reply to the inquiries concerning savings accounts. Of this number 10,982 carried savings accounts, and they had 14,873,361 savings depositors and savings deposits of $\$ 5$,$673,861,104$.

A table showing the savings facilities and the post office facilities possessed in 1909 by each state and territory, and by each geographic section of the country, was prepared by the author in 1911. ${ }^{18}$ Its story may be summarized as follows:

The table shows that the country as a whole was nowhere nearly so well provided with banks receiving savings deposits as with post offices, and that the section in which savings facilities were most lacking, whether viewed from the

${ }^{16}$ Ibid., p. 48.

${ }^{17}$ Ibid., p. 52.

18 The United States Savings Bank, in Political Science Quarterly, XXVI, pp. 468-472. 
ESTABLISHMENT OF THE SYSTEM 11

TABLR 1

Comparison of Bank facilities for Satings Deposits and of Post Office Facilities in 1909

\begin{tabular}{|c|c|c|c|c|c|}
\hline \multirow{3}{*}{$\begin{array}{l}\text { GEOGRAPHIC } \\
\text { SECTION }\end{array}$} & \multirow{2}{*}{\multicolumn{2}{|c|}{$\frac{\text { AREA }}{\text { Square miles to each }}$}} & \multirow{2}{*}{\multicolumn{2}{|c|}{$\begin{array}{c}\text { Population } \\
\text { Population to each }\end{array}$}} & \multirow{3}{*}{ 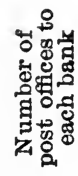 } \\
\hline & & & & & \\
\hline & Bank & Post offlce & Bank & Post offlce & \\
\hline New England States & 95 & 19 & 10,100 & 2,040 & 4.9 \\
\hline Eastern States ... & 57 & 14 & 10,700 & 2,560 & 4.2 \\
\hline Southern States & 418 & 35 & 13,600 & 1,120 & 12.1 \\
\hline Middle Western Stat's & 113 & 35 & 6,500 & 2,040 & 3.2 \\
\hline Western States . & 504 & 111 & 4,390 & 967 & 4.5 \\
\hline Pacific States. & 883 & 146 & 6,470 & 1,070 & 6.0 \\
\hline United States ${ }^{19}$. & 270 & 50 & 8.370 & 1,542 & 5.4 \\
\hline
\end{tabular}

standpoint of area or that of population, was the Southern States.

The case in favor of the post offices was in reality much stronger than the table shows. In the first place, the banks receiving savings are largely massed in the cities, each city of importance having a number of such institutions, while the post offices are widely scattered, no city having more than one independent post office. In the second place postal savings banks would presumably be opened at numerous sub-stations, not included in the above figures, while mail carriers on rural free delivery routes would probably be authorized to receive deposits for the postal savings banks, as in Holland, Belgium and France.

${ }^{19}$ Exclusive of island possessions. 
Conclusions based upon averages of the kind above given must of course be drawn cautiously, for the figures are not complete and the possible "fallacy of averages" is well known. The figures, however, are sufficiently complete, and the "story of the averages" is sufficiently truthful, to justify the conclusion that the country was many times over better provided with post office facilities than with savings bank facilities, and that this was particularly true of the Southern States.

\section{Fear of Competition with Existing Banks}

An objection strongly urged against the establishment of a postal savings system was that it would prove a competitor to existing banks. Opponents of a postal savings system argued that postal savings banks would have an undue advantage over private institutions because of the great confidence in the Government held by working people; and they said that funds would be withdrawn from existing banks and deposited in the postal savings banks. In support of this contention the experience of England was repeatedly cited, where, in the early days of postal savings, there had been a "marked tendency" for the postal savings banks "to absorb the patronage built up by the trustee banks."20

${ }^{20}$ J. H. Hamilton, Savings and Savings Institutions, 
The fear of such competition appears to have been the chief cause of the almost unanimous opposition on the part of the members of the banking fraternity to all postal savings bank proposals. Senator Cummins of Iowa said in the Senate: "The banks of the United States are opposed unanimously to the institution of a postal savings system. . . . I venture the assertion that during the nearly two years that $I$ have been a member of this body ... I have received the protests of nearly every bank in my State against any such scheme, and those protests have usually been accompanied by a very large number of petitions, secured, I have no doubt, through the industry and energy of the bank officers."21

The American Bankers Association, through the Postal Savings Bank Committee of its Savings Bank Section, carried on for nearly three years an active propaganda against postal savings bank legislation, maintaining an active opposition at Washington, ${ }^{22}$ and distributing over the country an immense amount of literature. ${ }^{23}$

p. 354. Cf. also William Lewins, History of Savings Banks, pp. 322 et seq.

${ }^{21}$ Cong. Rec., June 20, 1910, pp. 8811-8812.

${ }^{22}$ Cf. Chronicle, American Bankers Association Convention Supplement, 1909, pp. 207, 208 and 211.

${ }^{23}$ The following is an illustration of the character of the campaign which the Committee on Postal Savings Banks conducted. On November 24, 1908, when the Carter Postal 
The following resolution of the American Bankers Association at its convention of 1908 is fairly representative of the attitude of that association and of numerous State bankers' associa-

Savings Bank bill was before Congress, the committee sent a letter to bankers throughout the country, urging them to oppose the bill through their local newspapers and through their influence with members of Congress from their districts. The letter was accompanied by five exhibits: (1) a copy of the Carter bill; (2) a copy of an address in opposition to postal savings banks delivered by a banker who had been a Director of the Mint; (3) a copy of the report in opposition to postal savings banks adopted by the American Bankers Association at its convention in Denver; (4) a copy of an address by a Nebraska banker before the Wyoming Bankers Association and (5) "A condensed synopsis of the arguments against postal savings bank legislation to be used as a basis for newspaper articles."

The extremes to which this propaganda went are illustrated by the following quotations taken from the address referred to above as item $4:$

"The postal savings bank, that scheme which has been the dream of well meaning people with philanthropic tendencies for these many years, in the belief that they were conferring a blessing upon the race, and quickly supported by the great body of the American people, who are inclined to applaud enthusiastically anything done by the Government, may be engrafted upon our financial system. Never asked for by the thriftless whom it is desired to teach thrift, nor by the Slavic or Latin races who are pictured as sending so much money home, ... never requested as a personal desire by one single individual of our nearly ninety millions, [that scheme] threatens to be enacted into law."

“. . . The Postmaster General naïvely says: 'These postal savings banks will not compete in any way with our present banks.' He thinks he is stating a fact, doubtless, but as well might a highwayman, emptying a repeating 
tions throughout the country: "Resolved, that it is the sense of this association that we should condemn in unqualified terms the proposition for the establishment of postal savings banks or any other system by which the government enters directly into banking relations with the people."24

In reply the advocates of postal savings banks asserted that existing banks had nothing to fear from governmental competition; that they had the advantages of an established clientèle, higher interest rates, higher limits, if any, in the amounts that could be kept on deposit, and of the close personal and advisory relation which so often

Colt at you, say: 'I am shooting these bullets at you, but I do not intend to hurt you in any way.'

"[The advocates of postal savings banks] would have the Government cast loose from its moorings of protection for the individual and plunge into the frightful slough of socialism. The American people may well pause before they take this step, for the real persons injured are not the bankers in their individual capacity, but the nation at large. Socialism is not a mere harmless dream, impossible of fulfilment, to be tolerated as the well wishings of people more poetical than practical-it is a hideous growth of positive malevolence, and it is directly opposed to every fundamental principle of our government. It is an ingrate knocking at our doors, a thief at night creeping into our domiciles. It takes from industry its every reward and dampens energy and ambition with the stifling of the incentive for success. Well may we wake to the hidden currents of the stream of socialistic banking, before we take the fatal plunge!"

${ }^{24}$ Chron., A. B. A. Conv. Suppl., 1908, p. 131. 
exists between a bank and its customers. They further argued that postal savings banks would be a help rather than a hindrance to other banks. They would educate the people to habits of thrift and would draw money out of hoards, particularly those of the foreign born; and the deposits which the postal savings banks received would for the most part be transferred to other banks as soon as the limit fixed for postal savings bank deposits should be reached, or even before, as the depositor began to appreciate the safety of other banks and the advantage of their higher rate of interest. If the postal savings banks in the early days had been serious competitors of the trustee banks in England, it was pointed out, this was largely because of the shortcomings ${ }^{25}$ of those private banks; in most other countries, notably in Italy, ${ }^{26}$ the Netherlands, ${ }^{27}$ France $^{28}$ and Hungary, ${ }^{29}$ the postal savings banks had been found to be not competitors but co-workers.

${ }^{25} \mathrm{Cf}$. Lewins, chaps. 6, 7 and pp. 322 et seq.

${ }^{26}$ Hamilton, p. 373 ; also House Rep. No. 1445, 61 Cong.,

3 Sess., p. 2.

${ }^{27}$ Hamilton, p. 380.

${ }^{28}$ Ibid., pp. 381, 383.

${ }^{29}$ E. T. Heyn, Annals of the American Academy of Political and Social Science, VIII, p. 488. 


\section{Losses to Depositors from Bank Failures}

The immediate occasion of the last active movement for a postal savings bank system in the United States, as we have seen, was the losses and inconveniences arising from bank failures and from the suspension of cash payments in the panic of 1907. Naturally, therefore, the demand for greater safety of savings deposits played an important part in the discussion.

The advocates of postal savings banks cited figures showing the number of national bank failures and the losses involved, and similar figures for savings bank failures in certain States. They made much of the large amounts involved and of the hardships in individual cases. On the other hand, the opponents of postal savings banks usually dealt with percentage figures rather than with absolute amounts, and showed that for recent years the average losses, in terms of percentage of the amounts on deposit, were almost infinitesimal.

The figures cited for bank failures, so far as they related to savings deposits, were so incomplete as to be of doubtful value in measuring the extent of the losses. ${ }^{30}$ Those given by the Comp-

${ }^{30}$ Commenting upon this subject, Miss Florence Kelly recently said: "It is one of the gross sins of omission of our Government (State and Federal) that we have no trust- 
troller of the Currency ${ }^{31}$ showed that during the eighteen years 1892-1909 inclusive there were in the United States 1523 bank failures (exclusive of national banks); with total assets of $\$ 457$,640,000 , and total liabilities of $\$ 565,345,000$. In these figures are included 153 failures of banks which were strictly savings banks, with assets of $\$ 47,717,000$ and liabilities of $\$ 51,786,000$. Within the same period 344 national banks failed (exclusive of those restored to solvency and permitted to resume business within a year of report). In these national bank failures the net loss to depositors reported was $\$ 16,806,062 .^{32}$ Doubtless a considerable percentage of this sum represented small accounts of a saving or "semisaving" character-how much is not known.

After all, such figures give us no adequate measure for losses of this kind. "Among the experiences of working people none is more demoralizing and few are more cruel than loss of savings through failure of banks or absconding of individuals intrusted with funds." 33 To such people there is cold comfort in the assurance worthy data as to the extent of these losses year by year." Charities, XXI, p. 718.

31 Rep., 1909 , p. 69.

${ }^{32}$ National Monetary Commission, Statistics for the United States, 1867-1909, pp. 40-41.

${ }^{33}$ Florence Kelly, Charities, XXI, p. 717. 
that the average loss of savings bank depositors over a long period of years is but a fraction of a mill on a dollar. The loss is theirs: it is not, like the figures, distributed among all depositors by a mathematical average.

\section{Attracting Money from Hoards}

In urging that postal savings banks would draw money from hoards into circulation, the advocates of the scheme claimed also that such banks would keep in the United States money that would otherwise be sent abroad by foreigners. Although numerous estimates-more correctly, guesses-have been made from time to time as to the amount of hoarded money in the United States, we have no information of value on this subject. The distrust which causes hoarding makes it impossible to secure information concerning the amount hoarded. Much was made of the fact that every year many millions of dollars in money orders payable to self were bought for savings purposes. The number so bought in first and second class post offices alone for the year ending March 1, 1908, was 127,623, representing a total value of $\$ 8,054,894 .{ }^{34}$ In such cases the purchaser not only failed to receive any interest on his savings but was required

${ }^{34}$ House Doc. No. 1445, 61 Cong., 2 Sess., p. 93. 
to pay the money order fee. Many immigrants, moreover, distrusted American banks, and, being familiar with postal savings banks in their home countries and having great confidence in government institutions, remitted their savings to these home banks. How extensively this was done there are no figures to show. ${ }^{35}$

${ }^{35}$ Cf. George von L. Meyer, Postal Savings Banks; North American Review, CLXXXVIII, pp. 250-252. 


\section{CHAPTER II}

The Postal Savings Bank Act of 1910

Passing now from the general arguments which played an important rôle in the agitation for a postal savings bank system in the United States, we may consider the chief provisions of the organic act, which was passed by Congress in June, 1910, paying some attention, wherever it would be helpful, to the legislative history of the provision. These provisions will be taken up in the following order: administrative organization; deposits and withdrawals; rate of interest on deposits; and disposition of funds, including investment, and deposit in banks. Under the last item will be considered the question of the constitutionality of a postal savings system, a subject closely related to that of the investment of funds.

\section{Administrative Organization}

For "the control, supervision, and administration of the postal savings depository offices" and of the funds received on deposit, the act created a Board of Trustees consisting of the Post- 
master-General, the Secretary of the Treasury and the Attorney-General. On these trustees was conferred "power to make all necessary and proper regulations for the receipt, transmittal, custody, deposit, investment and repayment of the funds deposited at postal savings depository offices." This board is somewhat similar to the Postal Savings Bank Investment Board of the Philippines. ${ }^{1}$ The three officials are supposed to represent respectively three important aspects of postal savings bank work, administrative, financial and legal. The establishment of a postal savings bank in the United States was looked upon by many of its sponsors as an experiment, and it was the clear intention of Congress to give wide discretionary powers to the Board of Trustees, so that they might feel their way carefully in extending and developing the system. ${ }^{2}$ As it passed the Senate, the Carter bill contained no provision for a board with wide discretionary powers but placed the administration in the hands of the Postmaster-General. This likewise was the plan in the substitute bill recommended to the House by the minority of the Committee on Post Offices and Post Roads. ${ }^{3}$ The minority

${ }^{1}$ Kemmerer, The Philippine Postal Savings Bank, in Annals Amer. Acad., XXX, No. 1, p. 48.

${ }^{2}$ Cf. House Report No. 1445, 61 Cong., 2 Sess., pp. 1-2.

${ }^{3}$ Ibid., p. 103. 
asserted that the creation of a board of trustees was unnecessary, that it complicated the administration, and that the board as created was given too much power, particularly in the selecting of post offices to be postal savings banks.

The desire to give wide discretionary power to the administration, which was the motive of the change from a single head to a board of trustees, found expression in the provision for opening postal savings banks. ${ }^{4}$ As the bill came from the Senate to the House it provided for the establishment at once of postal savings banks in all first, second and third class post offices; while the bill as it passed the House and finally became law merely authorized the Board of Trustees "to designate such post offices as it may select to be postal savings depository offices." On this point the bill met vigorous opposition. It was urged

${ }^{4}$ The postal savings laws and the official administrative orders, regulations, announcements, etc., with few exceptions, avoid the use of the term "bank" in referring to the post offices which receive postal savings deposits. A post office which receives such deposits is usually called a postal savings depository, or a postal savings depository office, and a bank receiving postal savings funds on deposit from the postal savings system is known as a depository of postal savings funds. Fortunately the public need not follow these circumlocutions. In this volume a post office receiving deposits will be called a postal savings bank, and a banking institution receiving postal savings funds will be called a depository bank. 
that this was a dangerous power to confer upon an administrative board of political appointees; that political motives would dictate the selection of places for postal savings depositories; and that the banking community, with its powerful and organized opposition to postal savings banks, would be able to bring sufficient pressure on the Board of Trustees to prevent it from establishing depositories in important places. ${ }^{5}$

\section{Deposits and Withdrawals}

The limitations fixed by the law with reference to the character of deposits and the persons from whom deposits were to be receivable conformed fairly closely to the practices prevailing in other countries. Accounts could be opened by any person ten years of age or over, but no person could have more than one postal savings account at one time. Deposits could be made only in sums of a dollar or a multiple thereof; no one was to be permitted to deposit more than $\$ 100$ in any one calendar month; and the balance to the credit of any one person could not exceed $\$ 500$,

${ }^{5}$ Opponents of the bill called attention to the fact that the chairman of the Board of Trustees, the PostmasterGeneral, was the head of a Department which had a large amount of political patronage, and that the PostmasterGeneral of that time had but recently been chairman of the Republican National Committee. 
exclusive of accumulated interest. It is obvious that these latter two restrictions were made for the purpose of confining the use of postal savings banks to small savings and of preventing them from competing with other banks for the savings of well to do depositors.

To encourage petty savings, particularly among children, postal savings stamps in denominations of ten cents could be sold, which when pasted upon a card provided for the purpose could be deposited in sums of one dollar. Instead of giving the card free, as is the custom in most countries, and providing for the attaching to it of adhesive stamps to the full amount, there was an interesting innovation in the arrangement that the card was to be sold for ten cents and to require the attachment of only nine ten cent stamps to bring the value to a dollar.

There was little that is noteworthy in the provisions for withdrawing funds. A depositor might withdraw all or any part of his funds upon demand, "under such regulations as the Board of Trustees may prescribe. Withdrawals shall be paid from the deposits in the State or Territory, so far as the postal funds on deposit [in banks] in such State or Territory may be sufficient for the purpose, and, so far as practicable, from the 
deposits in the community in which the deposit was made." 6

This latter provision was of course part of the arrangement for keeping "at home" money deposited in the postal savings banks. Funds to meet withdrawals were to be paid by postmasters out of their daily postal receipts. Each postal savings bank, moreover, was to keep a small working balance to its credit at a local or neighboring bank. The size of this "emergency credit" was to be determined for each postal savings bank by the Board of 'Trustees and might be increased or diminished at the discretion of the board. "If the emergency credit is insufficient to meet the demands of his office, he [the postmaster] must immediately report the fact to the Board of 'Trustees, which reserves the right to defer payment until the necessary funds can be furnished the postmaster."7 A five per cent reserve against all deposits was required to be kept by the trustees at the Treasury in Washington. ${ }^{8}$

Thus postal savings banks were protected by a fourfold arrangement against dangers arising from sudden runs. In the first place, the postmaster had the use of his daily cash balance; in

${ }^{6}$ Sec. 8.

${ }^{7}$ Postal Savings System Regulations, promulgated by authority of the Board of Trustees, section 16 .

${ }^{8}$ Postal Savings act, sec. 9. 
the second place, he had an elastic "emergency credit" at a neighboring bank; in the third place, there was a five per cent cash reserve kept in the Treasury of the United States; and, in the fourth place, there was the provision that payment to depositors might be deferred. These safeguards (interpreted in connection with the provisions for the investment of funds to be referred to later ${ }^{9}$ ) were more than ample to meet any probable emergency. In England there is no special reserve requirement for postal savings bank deposits, and the amount of cash kept on hand is very small. ${ }^{10}$ This appears to be the rule in most other countries. If we consider the practice in the United States in the matter of savings bank reserves and select for comparison the most conservative class of savings banks, mutual savings banks, in the two States where they are most numerous, we find that in 1910 - the year in which the Postal Savings Bank act was passed -the 190 mutual savings banks of Massachusetts, with over three-quarters of a billion dollars

${ }^{9} \mathrm{Cf}$. infra, pp. 106 et seq.

${ }^{10}$ In 1903 it was 0.12 of one per cent of liabilities; in $1904,0.23$; in 1905, 0.32; and in 1913,0.40. The Economist, in criticizing the postal and trustee savings banks of England, said a generation ago: "Neither of them keeps any reserve of ready cash and both of them are entirely dependent on the sufficiency or insufficiency of the banking department of the Bank of England." XXXIII, p. 633. 
of deposits, kept a cash reserve of less than onefourth of one per cent, and a reserve of cash on hand and on deposit in other banks of 2.25 per cent; and that in the same year the 142 mutual savings banks of New York State, with over a billion and a half of deposits, held a cash reserve of less than nine-tenths of one per cent and a reserve of cash on hand and in banks of but 6.3 per cent. The 638 mutual savings banks of the entire United States, which reported to the comptroller in 1910, with total deposits of $\$ 3,361,000$,000 , had cash on hand of but $\$ 24,463,000$, or about three-fourths of one per cent, and cash on hand plus net cash in banks of but $\$ 117,525,000$, or about 3.5 per cent. ${ }^{11}$

In connection with the matter of deposits and

${ }^{11}$ Comptroller's Report, 1910, pp. 738, 739. The situation as regards the reserves of the savings banks at the end of the fiscal year 1915 was as follows: The 196 mutual savings banks of Massachusetts with $\$ 917,000,000$ of deposits had a cash reserve of less than one-sixth of one per cent, and a reserve of cash on hand and on deposit in other banks of about $21 / 2$ per cent. At the same time the 140 mutual savings banks of New York State, with deposits of $\$ 1,774,000,000$, had a reserve of cash on hand of onehalf of one per cent, and of cash on hand and on deposit in other banks of about 7 per cent. The 630 mutual savings banks of the United States which reported to the Comptroller of the Currency in 1915, with total deposits of $\$ 3,951,000,000$, had a reserve of cash on hand of slightly over one-half of one per cent, and of cash on hand and on deposit in other banks of 5.2 per cent. 
withdrawals two somewhat controversial questions arose. The first was: should the administrative system be highly centralized, as in England and in the Philippines, so that records could be kept at the central office, where deposits would be credited and to which application must be made through a postal savings bank for the withdrawal of funds; or should the system be less centralized, the local postmaster keeping records of individual accounts, crediting deposits and paying withdrawals directly? The first plan, which is carried most nearly to its logical consequences in the Philippines, and which was embodied in the bill introduced by Senator Carter, April 2, 1908 (S. 6484), was said to have the advantage of greater safety, because responsibility for large sums of money would not be placed upon postmasters in all parts of the country. The centralized plan would also render it possible for a depositor to make deposits to the credit of his account at any postal savings bank in the country and to withdraw funds through any postal savings bank. The second plan, which was adopted, offers the advantages of much prompter service and probably of greater economy in administration, because much of the work which would otherwise require a large force of clerks at Washington can be done with little extra ex- 
pense by local postmasters. A high degree of centralization in such matters is much more difficult in a country of great distances like the United States than in a country like England. Even in England, moreover, the extreme centralization of the postal savings bank system is breaking down. Since 1905 it has been possible in England to withdraw on demand from the local office sums not exceeding one pound. ${ }^{12}$

The second controversial question with reference to deposits and withdrawals, which is closely related to the first, was the question of the form in which the depositor's account should be keptwhether by pass book or by some kind of certificate of deposit. In all other countries, so far as the writer knows, the depositor's account is evidenced to him in the form of a pass book, in which debits and credits are entered and balances struck. This method was proposed for adoption in the majority of the postal savings bank schemes which received the serious attention of Congress. It was proposed in the bill which became law, as this bill originally passed the Senate. The other plan, that of evidencing the account by some sort of certificate of deposit, was urged for the United States on the ground that it would be simpler, easier and more economical of admin${ }^{12}$ Sen. Doc. No. 658, 61 Cong., 3 Sess., p. 25. 
istration and less open to mistakes and to fraud..$^{13}$ After considerable discussion of the comparative merits of these plans, Congress decided to leave the decision of this question to the Board of Trustees. ${ }^{14}$

\section{Rate of Interest}

The question of the rate of interest to be allowed to depositors resolved itself into two questions: How should the rate of interest be determined and what rate should be adopted?

Taking up these questions in their order, it may be noted that, while in most countries the rate is fixed by law, in some, as for example in Italy, in Tasmania and in the Orange River Colony, the rate is fixed by administrative authority and varies from time to time according to the earnings realized on the postal savings banks' investments. Hamilton, ${ }^{15}$ commenting upon the Italian method, says: "In fixing the rate of interest to be paid to depositors, the Italian Government has followed the true principle of savings bank management, that is, the rate is not

${ }^{13}$ It was also advocated on the ground that certificates might serve as a medium of exchange in times of panic and give greater elasticity to our currency. Cf. Albany Law Journal, LXX, pp. 346, 349.

14 Postal Savings Bank act, sec. 5.

${ }^{15}$ Savings and Savings Institutions, p. 370. 
fixed permanently, but it is determined from time to time by the earning power of the deposits." In the discussions in this country, both in Congress and outside, it seems to have been generally taken for granted that the rate of interest would be fixed by law. This plan appears to be the more reasonable one, when we consider that the postal savings bank was looked upon primarily as an institution for the encouragement of small savings-an institution which would serve as a sort of feeder to other savings banks and to other forms of investment where the interest yield would be higher. Furthermore, there were obvious political objections to placing in the hands of a politically partisan body like the Board of Trustees the responsibility of determining from time to time the rate of interest to be paid on the savings of depositors who presumably would soon be numbered by millions.

The second phase of the interest question was that of the rate itself. There were several obvious reasons for a relatively low rate of interest: (1) It was generally admitted that the postal savings bank system should be self-supporting and that the investment of its funds should be absolutely safe. This meant that the interest rate paid to depositors must be lower than that realizable on high grade investments by a percentage 
sufficient to meet administrative expenses.

The proponents of postal savings banks were very positive in their claim that these banks would be feeders of other banks rather than competitors. Had not this contention been widely accepted as true, it is very doubtful if a postal savings bank act could have been passed. If postal savings banks were not to compete with other banks, and if individual deposits, as soon as they reached substantial amounts, were to be transferred to other banks, the interest rate paid by postal savings banks must obviously not be so high as that paid by the best savings banks in the most populous sections of the country. ${ }^{16}$ (3) If the rate of interest should be fixed too

${ }^{16}$ The National Monetary Commission, in its Special Report from Banks of the United States as of April 28, 1909 (pp. 36-46), tabulated the average rate of interest paid on savings accounts by the different kinds of banks in the various States. These figures show the average rate paid by mutual savings banks in all States to have been 3.85 per cent, the lowest average in any State having been in Pennsylvania, 3.32 per cent, and the highest in West Virginia (only one bank), 4.5 per cent. The average rate paid by national banks in all States was 3.34 per cent, the average local rates having ranged from 4.66 per cent in North Dakota to 2 per cent in the District of Columbia. The average rate paid by State banks was 3.71 per cent, the average local rates having ranged from 5.14 per cent in North Dakota to 2.62 per cent in Delaware. The average rate paid by stock savings banks was 3.60 per cent, the average local rates having ranged from 4.35 per cent in Georgia to 2.71 per cent in the District of Columbia. 
high at first, as it had been in Canada, ${ }^{17}$ it would be difficult to reduce the rate because of political pressure; if, on the other hand, experience should prove the rate to be too low, as was discovered to be the case in the Philippines some years ago, ${ }^{18}$ it could readily be raised. These considerations led to the selection of the rate of 2 per cent, "the same to be computed on such basis and under such rules and regulations as the Board of Trustees may prescribe." ${ }^{19}$ This rate is a low one as compared with that paid in other countries. It was in fact then, and is still, the lowest rate paid on savings deposits by any postal savings bank in the world. ${ }^{20}$ The United Kingdom paid 2.5 per cent, Canada 3 per cent, France 2.5 per cent, Japan 4.2 per cent, Austria 3 per cent, Hungary 3 per cent, Sweden 3.6 per cent, and the Philippine Islands 2.5 per cent. When it is remembered that the prevailing rate of interest was normally higher in the United States than in most countries of Europe, it is clear that Congress did not err in the direction of too high a rate.

${ }^{17}$ Hamilton, Savings and Savings Institutions, pp. 415419.

${ }^{18}$ Report of the Chief of the Bureau of Insular Affairs, 1910, p. 6.

${ }^{19}$ Sec. 7 of act.

${ }^{20}$ See tables following p. 128, Sen. Doc. No. 658, 61 Cong., 3 Sess. 


\section{Investment of Postal Savings Funds}

The most difficult problem which Congress had in formulating its postal savings bank plan in 1910 was that of the investment of the deposited funds. In most countries postal savings funds are invested in the public debt, but such a disposition of them in the United States was out of the question because the United States public debt was small and was not looked upon as permanent, and because most of it was already tied up as security for national bank note circulation. There was a widespread belief both in Congress and outside that any feasible plan for the investment of postal savings funds must meet five requirements: (1) The investments must be safe. (2) Either all or a substantial proportion of them must be payable on demand since the postal savings deposits were to be demand deposits. (3) The investments must yield a sufficient rate of interest to pay the interest due to depositors and the expenses of administration. (4) The funds must be kept for the most part in the local communities where the deposits are received. The idea of the desirability of keeping "the money at home" was almost a fetish both among the advocates and among the opponents of postal savings 
legislation. Local communities throughout the country under the leadership of local bankers and of the Postal Savings Committee of the Savings Bank Section of the American Bankers Association were not backward in letting their representatives in Congress know that, if postal savings banks were to be established, they desired the deposited funds to be kept at home, and at all costs to be prevented from flowing to Wall Street. (5) The investments must take such a form as to make the postal savings bank system constitutional. In the light of these postulates, let us consider some of the salient points in the progress of the investment provisions of the Postal Savings Bank bill through Congress.

According to the bill as it stood a few days before its first passage in the Senate, the funds received on deposit were normally to be deposited (except for a small cash reserve fund at Washington), at not less than $2 \frac{1}{4}$ per cent interest, in banks situated in the locality where the deposits were received, "substantially in proportion to the capital and surplus of each such bank"; and the money was not to be withdrawn except to pay depositors when demanded. These deposits were to be secured by such indemnity bonds as the Board of Trustees might prescribe. A bank might deposit acceptable collateral in lieu of an 
indemnity bond. These provisions appeared to a majority of the Senate to meet the requirements of safety and of an adequate interest yield, and to keep the funds in the local community as effectually as any plan that could be devised. Shortly before the bill came to its vote in the Senate, however, it was vigorously attacked on the ground of unconstitutionality, particularly by Senators Rayner of Maryland, Bailey of Texas and Root of New York. The principal defenders of the constitutionality of the bill were Senators Sutherland of Utah and Bradley of Kentucky. The constitutional arguments were on an unusually high plane. The constitutionality of the bill was defended, of course, under the doctrine of implied powers. Ignoring the discussion over the "welfare clause" of the Constitution, which on the one side was interpreted to mean almost everything and on the other side to mean almost nothing, we find the proponents of constitutionality basing their arguments chiefly on three clauses of the Constitution. (1) The power "to coin money" and "regulate the value thereof" was to be interpreted "to confer upon Congress the power not only to coin money but to provide and maintain an adequate currency for the country." Postal savings banks would be a proper means to that end, since they would call 
money out of hoards and keep it in circulation. ${ }^{21}$ (2) The power "to regulate commerce ... among the several States" justified the establishment of a postal savings bank system, since these banks would assist interstate commerce in a most vital way, in bringing money into circulation and providing for the people an adequate supply of currency. ${ }^{22}$ (3) Senator Sutherland contended that the power "to establish post offices and post roads" had been broadly interpreted and acted upon as though it read: "Congress shall have power to establish, organize and define the functions of a postal department." In no other way, he said, could the broad powers now exercised by the Post Office Department be justified-powers such as that of the Postmaster-General to negotiate and conclude postal treaties and conventions with foreign countries, and that of providing for the issuing of money orders, both foreign and domestic. ${ }^{23}$

To these arguments the most effective reply was that made by Senator Bailey. No power, he maintained, had been conferred upon Congress to establish institutions for the encouragement of economy and thrift, which was the real

${ }^{21}$ Senator Sutherland, Cong. Rec., March 2, 1910, pp. 2652, 2653.

${ }^{22}$ Ibid., pp. 2653, $265 \mathrm{t}$.

${ }^{23}$ Cong. Rec., March 3, 1910, p. 2655. 
and declared purpose of the proposed legislation. Nor could such a power be brought by implication under any power expressly conferred upon the Federal Government. Under the coinage clause, he said, Congress has the power and the duty to provide the country with an adequate circulation, but when it "has exercised that power and performed that duty and the money so coined or issued has passed into the hands of the individual citizen, it is his private property and he has a right to do whatever he pleases with it." ${ }^{24}$ With reference to the claim that the right to establish a postal savings bank system was implied in the commerce clause of the Constitution, Senator Bailey said: "Banking is not commerce; but ... if it were admitted that the banking business is commerce within the meaning of the Constitution, such an admission would not justify this bill, because the only commerce which is subject to Federal regulation is a commerce among the several States, or with Indian tribes, or with foreign nations. ... To receive money at the post office and to deposit it in a bank situated in the same community is not commerce at all; and certainly it is not interstate or foreign commerce." ${ }^{25}$

${ }^{24}$ Ibid., March 3, 1910, p. 2689.

25 Ibid., pp. 2687, 2688. 
With reference to the claim that the right of Congress to create a postal savings bank was implied in the power conferred by the Constitution to establish post offices and post roads, Senator Bailey said: "There is absolutely no pretence that the deposit of private money with a postmaster, and the redeposit of it by him in a bank, has, or is intended to have, any connection with the use of the mails. It is a fiscal operation pure and simple, without the remotest relation to a post office or a post road as they were understood by the fathers when they framed our Constitution or as they are understood by us today. The Congress of the United States has just as much right and power to require our postmasters to act as commission merchants as it has to require them to act as bankers." 26

The constitutional status of the bill seemed weak even to many of its proponents, and a number of amendments were proposed calculated to give it a firmer position. These amendments for the most part undertook to make the bank more of an instrument for the borrowing of money by the Federal Government, and thereby to bring it more fully under the constitutional power "to borrow money on the credit of the United States." Some of these amendments went much ${ }^{26}$ Cong. Rec., March 3, 1910, p. 2688. 
farther than others; but the so-called Smoot amendment appeared to be the only one which could at the same time accomplish the purpose of making the bill constitutional and command a majority vote of the Senate. This amendment provided: "That when, in the judgment of the President, war or any other exigency involving the credit of the Government so requires, the Board of Trustees may withdraw all or any part of said funds from the banks and invest the same in bonds or other securities of the United States."27

Senator Root said: "I deem it my duty, in governing my own conduct and in expressing my opinions regarding this bill to my fellow Senators, to say that, without the amendment that I introduced or some one of these other amendments embodying the idea of investment in Government bonds, the bill is not within the constitutional power of Congress. I do not think that as it now stands it can be brought within the just description of any means necessary and appropriate or adapted or suitable or tending toward the exercise of any of the powers conferred."

Senator Root thought that the Smoot amendment, although not satisfactory to him, would "furnish probably a constitutional basis for the ${ }^{27}$ Ibid., p. 2720. 
proposed legislation, because it would present a purpose on the part of Congress to gather these earnings from the people and put them in such a position that the Government can call upon them whenever it has real need." 28

Senator Bailey admitted that the proposed amendment might make it possible for the court to hold the bill constitutional, but he declared that "it would still be none the less unconstitutional, according to the conscience of every Senator, because we all know that its purpose is not to borrow money, and to incorporate such a provision in it would be a palpable subterfuge invented to deny the court the right to consider the bill according to its real purpose." 29

The Smoot amendment passed the Senate; but its further consideration here is unnecessary because of the radical changes in the investment provisions of the bill which were made in the House. By these changes the bill, which soon became law, was greatly strengthened in its constitutional position, under the clause conferring upon Congress the power to borrow money on the credit of the United States. It was strengthened, however, at the expense of that other feature which so many believed essential to a satis-

${ }^{28}$ Cong. Rec., Mar. 4, 1910, p. 2761.

${ }^{29}$ Ibid., Mar. 3, 1910, p. 2688. 
factory law, namely, the requirement that the moneys deposited in postal savings banks should be kept as far as possible in the local communities where the deposits were received.

This explanation will give the reader the underlying philosophy of the investment features of the act, ${ }^{30}$ which were briefly as follows: Postal savings funds were divided into three parts: (1) A 5 per cent reserve fund to be kept in lawful money in the Treasury of the United States; (2) a sum not exceeding 30 per cent of the amount of postal savings funds, which "may at any time be withdrawn by the trustees for investment in bonds or other securities of the United States"; (3) a sum, which normally should be not less than 65 per cent of the total postal savings deposits, to be kept on deposit "in solvent banks, whether organized under national or State laws, being subject to national or State supervision and examination. . . ."31 It was declared to be the intent of the act that this residual 65 per cent should remain on deposit in the banks in each State and Territory willing to receive them, ${ }^{32}$ and should be a working balance and a fund which might "be withdrawn for investment

${ }^{30}$ Act, sec. 9.

31 The word "bank" was declared by the act (sec. 9) to "include savings banks and trust companies doing a banking business."

${ }^{32}$ The funds received at the postal savings depository 
in bonds or other securities of the United States, but only by direction of the President, and only when, in his judgment, the general welfare and the interests of the United States so require."

Postal savings funds deposited in banks were to bear interest at a rate of not less than 21 per cent. The provision in the Senate bill, that banks might give indemnity bonds as security for deposits of postal savings bank funds, was cut out, and in its place was inserted the provision: "The Board of Trustees shall take from such banks such security in public bonds or other securities, supported by the taxing power, as the board may prescribe, approve, and deem sufficient and necessary to insure the safety and prompt payment of such deposits on demand."

These provisions for the regular or contingent purchase of government securities were sup-

offices in each locality were to be deposited "in banks located therein (substantially in proportion to the capital and surplus of each such bank) willing to receive such deposits under the terms of this act and the regulations made by authority thereof. . . . If no such bank exist in any city, town, village, or locality, or if none where such deposits are made will receive such deposits on the terms prescribed, then such funds shall be deposited under the terms of this act in the bank most convenient to such locality. If no such bank in any State or Territory is willing to receive such deposits on the terms prescribed, then the same shall be deposited with the treasurer of the Board of Trustees, and shall be counted in making up the reserve of five per centum." Sec. 9, Post. Sav. act. 
ported on the following grounds: the greater safety of the funds invested in government bonds or secured by them; the stronger constitutional position given to the bank; and the fiscal advantage to the Government in times of emergency. They were opposed principally on the ground that they would result in the withdrawal of funds from the local communities and in their transfer to financial centers. ${ }^{33}$

\section{Postal Savings Bonds}

Closely related to the subject of the investment of postal savings bank funds in government

${ }^{33} \mathrm{Cf}$. views of minority members of Senate Committee on Post Office and Post Roads, House Report No. 1445, 61 Cong., 2 Sess., pp. 102, 103. Senator Heyburn of Idaho said, referring to the bill in its final form, a few days before it became law: "This is a through ticket to the money of the country to New York. There is no return ticket in this bill." Cong. Rec., June 30, 1910, p. 8816 . See also the speech of Senator Bacon of Georgia. Ibid., June 21, p. 8947.

For a criticism of postal savings banks on the ground that they will draw money away from local investments, where it is most needed, and cause it to flow into investments of a national character bearing low rates of interest, see article by George E. Roberts, N. Amer. Rev., Feb. 15, 1907.

The provision that the funds deposited in banks might be withdrawn and invested in United States securities by direction of the President, whenever in his judgment the general welfare so required, was strongly criticized on the ground that it placed a large and dangerous power in the hands of the President. 
bonds is the provision of the act ${ }^{34}$ that any depositor in a postal savings bank may surrender his deposit, or any part thereof, in sums of $\$ 20, \$ 40$, $\$ 60, \$ 80, \$ 100$ and multiples of $\$ 100$, and $\$ 500$, and receive therefor the amount surrendered in United States coupon or registered bonds of the denominations mentioned above. These bonds bear interest at the rate of $2 \frac{1}{2}$ per cent, payable semi-annually, and are redeemable one year from date and payable twenty years from date. They may be issued "only (first) when there are outstanding bonds of the United States subject to call, in which case the proceeds of the bonds shall be applied to the redemption at par of outstanding bonds of the United States subject to call, and (second) at times when under authority of law other than that contained in this act the Government desires to issue bonds for the purpose of replenishing the Treasury, in which case the issue of bonds under authority of this act shall be in lieu of the issue of a like amount of bonds issuable under authority of law other than that contained in this act."

Aside from its relation to the subject of the retirement of United States 2 per cent bonds and to various proposals for banking reform which were before the public in 1910, this provision of

${ }^{34}$ Sec. 10. 
the law had four distinct merits, which may be called respectively legal, educational, political and fiscal: (1) The legal merit was that it strengthened the constitutional position of the bank as an instrument of the Federal Government with which to borrow money on the credit of the United States. (2) The educational merit was that it would encourage thrift by providing a safe investment for postal savings bank depositors when their deposits should reach the limit of $\$ 500$ then fixed by law, and that it would encourage the making of investments (as contrasted with bank deposits) by offering to the poor man perfectly safe bonds in small denominations which would yield an interest rate larger by one-half of one per cent than the rate paid on postal savings bank deposits. (3) The political advantage was that it would tend to place the public debt more largely in the hands of the poorer classes, as is the case in France, and to tie their interests more closely to those of the Government. (4) The fiscal advantages were: that it would in time presumably give the Government the power to float bonds (not carrying the privilege of being used as security for national bank note circulation) at a substantially lower rate of interest than would otherwise be possible; and that it would open a possible way for the conversion of the $\$ 63,945,460$ three per cent 
bonds of 1908-18 then payable at the pleasure of the Government.

The investment features of the Postal Savings Bank act can not be fully understood except in connection with the general subject of banking reform, which was before the public when the Postal Savings Bank act was passed. At that time the National Monetary Commission was at work on the subject of banking reform. One of the greatest defects of our national banking system was generally admitted to be the bond secured circulation. By reason of the privilege of being used as security for bank note circulation, the $\$ 731,000,0002$ per cent bonds then outstanding commanded a price much higher than they otherwise would have commanded in the market. The banks had purchased them in good faith, and if the circulation privilege were to be taken away, the Government would be under obligation to protect the banks from loss. The investment of postal savings bank funds, it was argued, would provide a method for the purchase of these bonds at par when the circulation privilege should be taken away from them, ${ }^{35}$ and they might then be converted by the Government into bonds bearing a proper rate of interest from the fiscal point of view.

${ }^{35} \mathrm{Cf}$. speech of President Taft on the subject of the Postal Savings Bank, Milwaukce, September 17, 1909. Cong. Rec., Feb. 17. 1910, pp. 2048-2050. 
The opposition to authorizing the investment of postal savings bank funds in 2 per cent bonds was very strong, particularly in the Senate; and to save the bill from defeat an amendment proposed by Senator Borah was adopted shortly before the bill came to its first vote in the Senate. It provided "that no part of said funds shall, in any event, be invested in bonds or other securities bearing interest at less than 21 per cent per annum." This amendment, however, did not survive the overhauling which the bill received in the House; and when the bill was returned to the Senate it contained no limitation whatever as to the character of United States securities in which postal savings bank funds might be invested.

We have now discussed the movement leading to the establishment of a system of postal savings banks in the United States and the chief provisions of the organic postal savings bank law of 1910. It will be our next task to discuss the workings of the system since it opened its doors for business January 3, 1911. For convenience the subject will be treated under the following heads, to each of which a chapter will be devoted: (1) administrative organization, and the selection of post offices for postal savings banks; (2) depositors and deposits; (3) investment of postal savings funds. 


\section{CHAP'TER III}

Administrative Organization and Selection of Post Offices for Postal Savings

\section{BANKS}

Since the opening for business of the first postal savings banks, on January 3, 1911, there have been numerous changes in the central administrative organization at Washington, the more important of which are deserving of note. A few months experience with the new system showed that much delay was occasioned by the inability of the three members of the Board of Trustees to get together promptly when needed. Accordingly the Post Office Department Appropriation act of March 4, $1911^{1}$ amended the postal savings law by giving to the Postmaster-General full authority with reference to the designation of postal savings banks, the making of rules concerning the deposit and withdrawal of funds, and some other matters originally entrusted to the Board of Trustees as a whole. The investment and control of postal savings deposits continued to be intrusted to the board.

${ }^{1}$ Sec. 5. 
In 1913 the administrative machinery of the postal savings system was reorganized and given a definite and permanent status in the Post Office Department, which it had previously lacked. On May 1, 1913, by administrative order of the Postmaster-General, such part of the administrative business of the postal savings system as had up to that time been under the immediate supervision of the Postmaster-General, together with the corps of employees doing the postal savings work, was transferred to the Bureau of the Third Assistant Postmaster-General-the bureau in charge of the fiscal affairs of the Post Office Department-and a division was created in that bureau, to be known as the Division of Postal Savings, for the immediate charge of this work. Contemporaneously the Third Assistant Postmaster-General was elected Secretary of the Board of Trustees and constituted its agent for all purposes connected with the administrative duties conducted through the central office in Washington.

Thus all postal savings business charged to the Post Office Department is performed in the Division of Postal Savings under the immediate supervision of the Third Assistant PostmasterGeneral as an officer of the Post Office Department, and all business of the Board of Trustees 
is performed through or by the same official, either in his capacity as secretary or as agent of the board for the performance of certain specified duties. ${ }^{2}$

Up to June 30, 1913, the employees of the central office of the postal savings system were paid out of a special fund appropriated for "establishing postal savings depositories." Beginning with the fiscal year 1914, however, the clerical positions in the Division of Postal Savings were made statutory, and the expenses of the division were made directly chargeable to the annual appropriation for the Post Office Department. At the time of the transfer of the postal savings system to the Bureau of the Third Assistant Postmaster-General, a committee of Post Office Department officials was appointed for the purpose of making a study of the regulations, instructions and forms in use by the postal savings system, and of recommending changes where they thought changes desirable. As a result of the committee's work many changes in procedure were drafted, some of the more important of which will be noted later. ${ }^{3}$

${ }^{2}$ Ann. Rep. 3 Assist. Postmast.-Gen., 1913, p. 28.

${ }^{3}$ Infra, pp. 116-123. 


\section{Selection of Depository Post Offices}

The postal savings system was inaugurated in January and February, 1911, by the opening of one postal savings bank in each State and Territory. From that time forward the work of extending the system to other places proceeded rapidly. By the end of the fiscal year 1913 banks had been opened in 12,151 post offices, including all Presidential offices and about 4,000 offices of the fourth class, also in 667 branches and stations. This fiscal year showed the high water mark in the number of banks. The Department, however, had moved too fast in opening new banks, particularly in fourth class post offices. It was pointed out by Representative William $\mathbf{H}$. Stafford of Wisconsin, ${ }^{4}$ in Congressional debate, that of the 4,000 fourth class post offices 3,000 either had no deposits at all or deposits of only one dollar. On the fee basis then used for compensating postmasters for their services in postal savings work, in these 3,000 offices average compensation allowed was 27 cents a year. ${ }^{5}$ Yet the auditors of the Post Office Department kept a separate account with each of these offices, and

${ }^{4}$ Cong. Rec., Dec. 15, 1913, p. 928.

${ }^{5}$ Representative Madden of Illinois, a member of the House Committee on Post Office and Post Roads, Cong. Rec., Dec. 10, 1913, p. 654 . 
monthly audits were frequent-all involving substantial expenses. During the fiscal year 19131914 postal savings functions were discontinued at 18 Presidential offices, 2,753 fourth class offices, and 8 branches and stations $;^{6}$ and at the end of the fiscal year 1916, the last date for which detailed figures are available, the total number of postal savings banks was $\mathbf{8 , 4 2 1}$, classified as follows: ${ }^{7}$

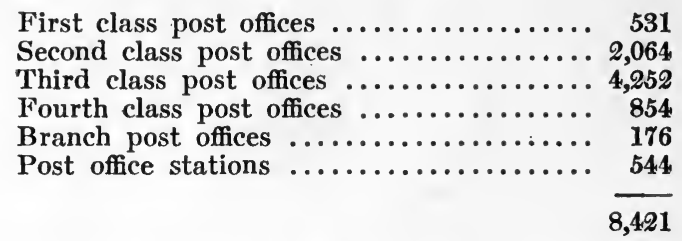

Notwithstanding the discontinuance of many postal savings banks in 1913-1914 and since, there are still a very large number of small and inactive banks The annual report of the Board of 'Trustees for the fiscal year 1915-16 gives for each city, town and village having a postal savings bank the amount of deposits held on June 30, 1916. An analysis of these figures

${ }^{6} \mathrm{~A}$ few of these changes were due to the discontinuance or the reclassification of the post offices. Some new banks were opened during the year, but notwithstanding this the year showed a net reduction of 2,473 in their number, bringing the total down to 10,347. Ann. Rep. 3 Assist. Postmast.-Gen., 1914, p. 6.

${ }^{7}$ Ibid., 1916, p. 32. In January, 1914, the system was extended to Hawaii and Porto Rico. 
made by the writer shows that 1,648 of the 8,421 postal savings banks had deposits of less than $\$ 100$ each; and of this number 509 banks did not have a single dollar of deposits, 259 had only $\$ 1$, 447 between $\$ 2$ and $\$ 10,299$ between $\$ 11$ and $\$ 25$, and 581 between $\$ 26$ and $\$ 99$. These figures seem to show that there is still ample room for the use of the pruning knife. 


\section{CHAPTER IV}

\section{Depositors and Deposits}

In the preceding discussion of the organic postal savings bank law it was pointed out that, after considerable discussion, Congress left the decision as to the form in which the depositor's account should be kept to the discretion of the Board of Trustees. Chiefly for the purpose of keeping administrative expenses at a minimum, the board decided to use in place of the customary pass book a simple form of certificate. This certificate is officially described as a "non-transferable and non-negotiable certificate of deposit, to be supplied to postmasters in duplicate in fixed denominations of one, two, five, ten, twenty, fifty and one hundred dollars, upon which shall be entered the name of the issuing office, the date of issue, the date on which interest begins, the name of the depositor, and the number of his account. ${ }^{1 \text { " }}$ On the back of each certificate is printed a ten year interest table. There is furnished to each depositor an envelope, in which he may preserve

${ }^{1}$ Instructions to Postmasters at Postal Savings Depository Offices, 1913, p. 7. 
his certificates. Upon this envelope is printed a certain amount of postal savings information, and a blank ledger for keeping account of deposits and withdrawals. With each deposit the depositor secures an additional certificate. As a matter of convenience to the depositor, however, the post office will exchange a certificate of large denomination for a number of certificates of small denominations.

Aside from the limitation of the amount a depositor can have to his credit, there is no limit to the number of certificates he may hold. The certificate system has been eminently successful, and the advocates of a pass book plan for postal savings banks are now very few.

\section{Nativity of Depositors}

The most striking fact in our experience with postal savings banks is the large extent to which they have been patronized by persons of foreign birth. In the United States the postal savings bank is to a large degree an immigrant's banka situation, so far as I have been able to learn, peculiar to this country. Mr. Carter B. Keene, Director of the Division of Postal Savings, in an address before the Savings Bank Section of the American Bankers Association on September 26, 1916, said that 375,000 , or 60 per cent of the total 
number of depositors, were born outside of the United States, and that this 60 per cent owned three quarters of all the deposits. ${ }^{2}$ Moreover, the proportion of foreign born among the depositors is increasing. About three years before, only 36 per cent of the depositors were foreign born and this 36 per cent owned 51 per cent of the amount on deposit. ${ }^{3}$

Analyzing the situation portrayed by these summary figures, one notices that some nationalities patronize the postal savings system much more extensively than others. The figures for the close of the fiscal year 1915 concerning the nativity of postal savings depositors ${ }^{4}$ are shown in column 1 of the following table, of which columns 2 and 3 based upon the census figures for 1910 - the latest available-have been added by the writer.

The last two per capita figures in column 3 show that in proportion to population the deposits of the foreign born are about 15 times as large as those of the native born. This comparison, however, involves the fallacy of an "age se-

${ }^{2}$ Com. \& Fin. Chron., Am. Bankers Assoc. Conv. Suppl., Oct. 14, 1916, p. 192.

${ }^{3}$ Ibid., 1913, p. 195.

4 The figures are given, along with a large amount of other postal savings information, in a pamphlet issued by the Post Office Department in 1916, entitled The United States Postal Savings System, p. 6. 
TABLE I

Nativity of Depositors in Postal Savings Banks

\begin{tabular}{|c|c|c|c|c|}
\hline \multirow[t]{3}{*}{$\begin{array}{c}\text { Country } \\
\text { of } \\
\text { nativity }\end{array}$} & $\begin{array}{c}1 \\
\text { Percentage } \\
\text { of total de- } \\
\text { posits made } \\
\text { by natives of } \\
\text { each country }\end{array}$ & \multicolumn{2}{|c|}{$\begin{array}{l}\text { Number and percentage } \\
\text { of population of U. S. } \\
\text { born in each country }\end{array}$} & $\begin{array}{c}3 \\
\text { Per capita } \\
\text { deposits }\end{array}$ \\
\hline & & Number & & \\
\hline & & $\begin{array}{c}(000 \\
\text { omitted })\end{array}$ & Per cent & Dollars \\
\hline Greece ..... & 1.8 & 101 & 0.11 & 11.70 \\
\hline Russia ..... & 20.7 & 1,732 & 1.86 & 7.85 \\
\hline Italy ....... & 14.2 & 1,343 & 1.44 & 6.95 \\
\hline Hungary ... & 4.3 & 496 & 0.53 & 5.69 \\
\hline Austria .... & 8.7 & 1,175 & 1.26 & 4.86 \\
\hline Sweden .... & 2.2 & 665 & 0.71 & 2.17 \\
\hline and colonies 5 & 8.8 & 3,768 & 4.04 & 1.53 \\
\hline Germany ... & 4.1 & 2,501 & 2.68 & 1.08 \\
\hline $\begin{array}{l}\text { Other for- } \\
\text { eign coun- } \\
\text { tries } \ldots \ldots \ldots\end{array}$ & 7.0 & 1,565 & 1.68 & 2.94 \\
\hline Total foreign & & & & \\
\hline countries .. & 71.8 & 13,346 & 14.3 & 3.53 \\
\hline United & & & & \\
\hline States $^{6} \ldots$ & 28.2 & 80,000 & 85.7 & 0.23 \\
\hline
\end{tabular}

lection" against the deposits by natives, since a much larger percentage of the foreign born than of the natives are 10 years of age or over and are therefore eligible to become depositors. This error in the crude figures may be approximately estimated. The thirteenth census showed that

${ }^{5}$ Covers only Great Britain, Ireland and Canada.

${ }^{6}$ Covers United States, Hawaii, and Porto Rico. 
about 75 per cent of the native whites were 10 years of age or over, and 97 per cent of the foreign born. Multiplying the crude figure $\mathbf{1 5}$ given above by $75 / 97$ we arrive at 10.9 as the correct figure showing the ratio of the per capita deposit in postal savings banks of the foreign born 10 years of age or over to that of the native born of the same age group.

Viewed by countries the figures show striking differences, the natives of Greece being well in the lead with a per capita deposit of $\$ 11.70$, or a figure 51 times as large as that for native born Americans. The natives of Russia and Italy follow closely with per capita deposits of $\$ 7.85$ and $\$ 6.95$ respectively, then come those of Hungary with $\$ 5.69$ and those of Austria with $\$ 4.86$. The per capita deposits for the natives of other countries fall far behind these figures, that for the American born, viz., 23 cents, coming up in the extreme rear.

Any satisfactory explanation of this situation would require a thoroughgoing investigation among the depositors themselves in the different communities most affected. With such evidence as is at present available, most of it coming from communications sent by postmasters and others to the Postal Savings Division at Washington, the best one can do is to name a few of the forces 
at work, without attempting to weigh them. Among these may be mentioned: (1) The distrust of non-Government banks on the part of the foreign born population-a distrust easily understood when one bears in mind the extent to which our foreign born have been robbed by persons (often of their own nationality) parading under the name "banker" or "bank." The exploitation of our thrifty foreign born population by many of our so-called "immigrant banks" has been a public disgrace." Although considerable improvement has been made in recent years in the regulation of these institutions, the situation is still far from perfect, and the distrust among the foreign born engendered by the early abuses still persists. (2) A second reason is the democratic atmosphere which pervades most post offices, in contrast with the aristocratic one that pervades most banks. Moreover, comparatively few banks have made a reasonable effort to attract this class of our population, while the postal savings system has. ${ }^{8}$ In receiving and sending

${ }^{7}$ Cf. Report of Immigration Commission, on Immigrant Banks, Sen. Doc. No. 381, 61 Cong., 2 Sess., pp. 109-124.

${ }^{8}$ Circulars in 23 foreign languages explaining the postal savings system and its advantages have already been issued and widely distributed. These 23 foreign languages are designed to reach about 97 per cent of our entire foreign born population. Ann. Rep. 3 Assist. Postmast.-Gen., 1916, p. 12. 
letters and in transmitting money to their families or others in the homeland the foreign born are frequently brought to the post office. The unskilled laborers among the foreign born would rarely be brought to an American savings bank or commercial bank by anything but the desire to deposit or withdraw money. Foreigners become familiar with the post office and not with the bank. (3) All of the first five countries in the list have postal savings banks, and immigrants from those countries have been familiar with such banks at home. (4) The European war through its interference with "immigrant banks," and with the sale of international money orders (an explanation of which is given by the Postmaster-General in his annual report for 1915, pp. 27-28), has encouraged the foreign born to keep their savings in the United States.

Of course the small per capita deposit of native born Americans does not signify any lack of thrift on their part. It means rather that the two per cent interest paid by the postal savings bank is too small to appeal to the native born, and that for this and other obvious reasons of less importance they place their savings elsewhere.

Inasmuch as the avowed object of the establishment of postal savings banks in the United States was the encouragement of thrift, it is nat- 
ural to ask: (1) How has the plan appealed to persons of different ages, and particularly how has it appealed to children who represent the part of our population whose education in thrift would appear to be the most important? and (2) How has it appealed to our negro population, which, as a whole, and allowing for numerous worthy exceptions, is our most thriftless class?

\section{Age Grouping of Depositors}

No recent figures are available for the age grouping of depositors. An investigation of this subject, however, was made as of June 30, 1912, after the postal savings system had been in operation a year and a half. The result of that investigation has been furnished the writer by the Third Assistant Postmaster-General, and is summarized in the following table, the last two columns of which have been added by the writer.

The table shows that children from 10 to 14 years of age constitute about four-fifths as large a percentage of the depositors as they do of the country's total population 10 years of age or over; while persons from 15 to 19 years of age constitute about two-thirds as large a percentage. The facts are considerably more favorable to children depositors than the figures show. This is true, first, because of the fact previously noted that 
TABle 2

Number and Percentage of Depositors, June 30, 1912, by Age Groups.

\begin{tabular}{|c|c|c|c|c|}
\hline Age groups & $\begin{array}{c}2 \\
\text { Number }\end{array}$ & $\begin{array}{c}3 \\
\text { Per cent }\end{array}$ & $\begin{array}{c}4 \\
\text { Per cent of } \\
\text { total popula- } \\
\text { tion } 10 \text { years } \\
\text { of age or } \\
\text { over in age } \\
\text { group in } 1910\end{array}$ & \begin{tabular}{|c}
$\mathbf{5}$ \\
Ratio of per- \\
centage of \\
depositors in \\
each age group \\
to group's per \\
centage of to- \\
tal population
\end{tabular} \\
\hline $\begin{array}{c}10-14 \text { years } \\
15-19 \text { “ } \\
20-24 \\
25-34 \text { “ } \\
35-44 \\
45-64 \text { “ } \\
65 \text { years and } \\
\text { over } \\
\text { Unknown } \\
\text { Total }\end{array}$ & $\begin{array}{r}25,108 \\
20,703 \\
32,529 \\
70,672 \\
45,488 \\
40,977 \\
\\
7,987 \\
337 \\
243,801\end{array}$ & $\begin{array}{r}10.3 \\
8.5 \\
13.3 \\
29.0 \\
18.7 \\
16.8 \\
\\
3.3 \\
0.1 \\
100.0\end{array}$ & $\begin{array}{l}12.7 \\
12.6 \\
12.6 \\
21.1 \\
16.2 \\
18.7\end{array}$ & $\begin{array}{r}.81 \\
.67 \\
1.06 \\
1.37 \\
1.15 \\
.90\end{array}$ \\
\hline
\end{tabular}

there is a very small percentage of children among that foreign born population which constitutes much over half of the postal savings depositors, and second, because the postal savings bank stamp cards and stamps, representing savings of less than a dollar, are probably used mostly by children, and the savings represented by outstanding cards belonging to persons who have not yet opened their accounts do not figure in the records. ${ }^{9}$

The table shows emphatically that it is among

${ }^{9}$ This item would be too small to be worthy of mention were it not for the fact that a very large percentage of the persons who figure in the statistics as depositors have deposits of only one dollar. 
the middle age groups that postal savings are most popular, the three age groups 25-34, 35-44, and 20-24, in their order, showing the largest proportions of depositors to the total population in the respective age groups.

\section{Negro Depositors}

The colored population, although it lives chiefly in the sections of the country where nongovernmental bank facilities are relatively lacking, has made little use of the postal savings system. As in the case of the age grouping of depositors, the only available statistics as to color grouping relate to June 30, 1912. At that time the total number of depositors was 243,801 and they were grouped as follows:

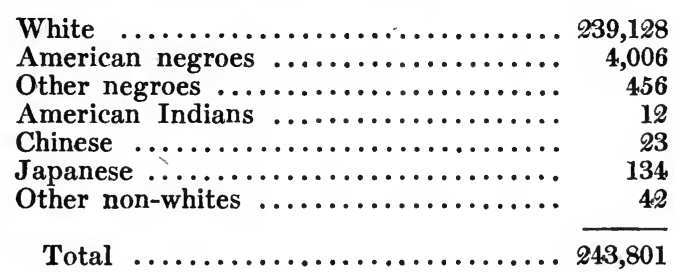

This gives the whites 98.1 per cent of the total, and the American negroes 1.6 per cent, whereas their respective percentages in the total population in 1910 were 88.8 and 10.7. Evidently the postal savings system is accomplishing practically nothing in reaching the negro population. This 
would appear to be a particularly important field for it to cultivate.

\section{Geographic Distribution of Deposits} and Depositors

Closely related to the subject of the character of the depositors is that of their geographic distribution. In fact, when one says that the bulk of the depositors are foreign born, names the nationalities that preponderate, and says there are few negro depositors, he has to a large extent answered the question of their geographic distribution, and has said that they come largely from the cities of the industrial communities. A further analysis of this situation, however, is justified by its importance. Table 3 on pages 68 and 69 and Map I on page 67 show the distribution by States. Briefly summarized the facts are as follows:

\section{Distribution of Depositors}

Taking the country as a whole there was one depositor on June 30, 1916, to every 172 of the population; but the proportion of depositors to the total population showed wide differences in different sections, varying from one depositor to every 47 of the population in Nevada to one to every 5,953 in South Carolina. There are 10 


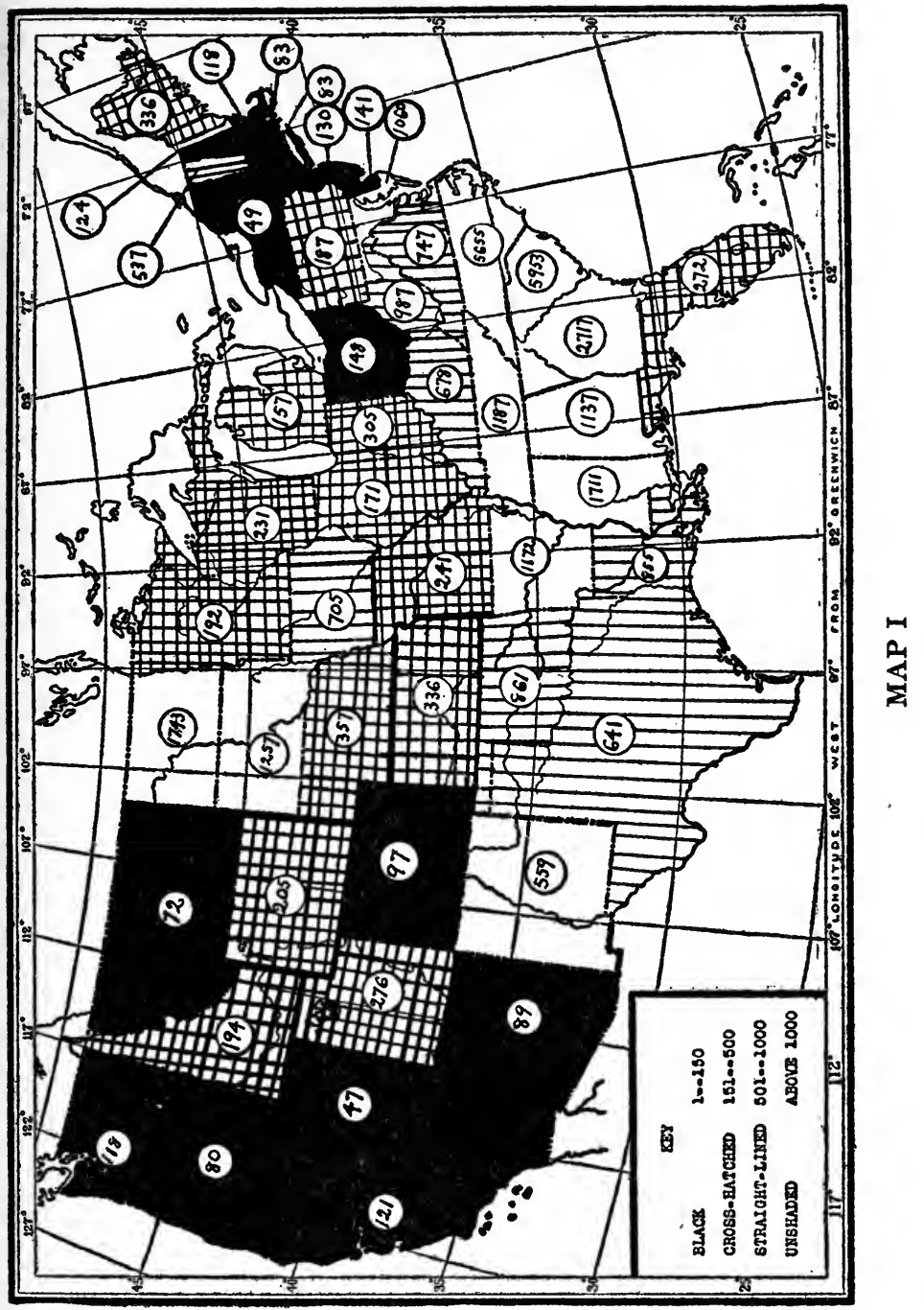


TABLE III

Statistics of Postal Savings by States, June 30, 191610

\begin{tabular}{|c|c|c|c|c|c|c|c|c|}
\hline \multirow{2}{*}{\multicolumn{2}{|c|}{$\begin{array}{c}\text { STATES } \\
\text { AND } \\
\text { TERRITORIES }\end{array}$}} & \multirow[b]{2}{*}{ 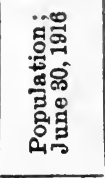 } & \multicolumn{2}{|c|}{ SAVINGS BANKS } & \multicolumn{2}{|c|}{ DEPOSITORS } & \multicolumn{2}{|c|}{ DEPOSITS } \\
\hline & & & 尝革 & 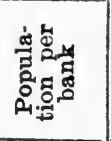 & 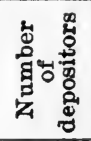 & 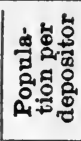 & 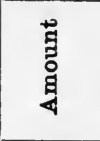 & 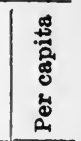 \\
\hline Alabama & & $\begin{array}{c}(000) \\
\text { omitted }) \\
2.333\end{array}$ & 92 & 25,360 & 2,051 & 1,137 & $\begin{array}{c}(000 \\
\text { omitted }) \\
\$ 222\end{array}$ & 80.10 \\
\hline Alaska . & 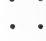 & 65 & 8 & 8,130 & 224 & 290 & 36 & 0.55 \\
\hline Arizona & 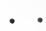 & 256 & 36 & 7,110 & 2,861 & 89 & 605 & 2.36 \\
\hline Arkansas . & . & 1,740 & 102 & 17,060 & 1,484 & 1,172 & 229 & 0.13 \\
\hline California . & . & 2,939 & 310 & 9,480 & 24,224 & 121 & 3,836 & 1.31 \\
\hline olorado. & & 962 & 130 & 7,400 & 9,917 & 97 & 1,652 & 1.72 \\
\hline Connecticut & . & 1,244 & 125 & 9,950 & 15,057 & 83 & 934 & 1.55 \\
\hline Delaware. & & 213 & 22 & 9,680 & 1,510 & 141 & 173 & 0.81 \\
\hline D. of Colum & bia & 364 & 9 & 4,045 & 2,723 & 134 & 373 & 1.02 \\
\hline lorida . . & . . & 893 & 85 & 10,5 & 3,277 & 272 & 364 & 0.41 \\
\hline łeorgia . . & & 2,856 & 91 & 31, & 1,051 & 2,717 & 122 & 0.04 \\
\hline Hawaii . & & 216 & 10 & 21,600 & 409 & 528 & 38 & 0.18 \\
\hline Idaho . & . & 429 & 84 & 5,110 & 2,215 & 194 & 381 & 0.89 \\
\hline Illinois . . & 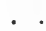 & 6,152 & 486 & 12,660 & 35,979 & 171 & 5,992 & 0.97 \\
\hline Indiana. & & 2,817 & 292 & & 9,251 & 305 & 1,377 & 0.49 \\
\hline Iow $a^{11}$. & & 2,225 & 268 & 8,300 & 3,155 & 705 & 527 & 0.24 \\
\hline Kansas & & 1,830 & 298 & 6,140 & 5,451 & 336 & 741 & 0.40 \\
\hline Kentucky . & . & 2,380 & 140 & & & 67 & 43 & 0.18 \\
\hline isiana. & . & 1,829 & 79 & 23,150 & 2,139 & 855 & 292 & 0.16 \\
\hline Ma & & 772 & 113 & & & 336 & 29 & 03 \\
\hline Maryland . & & 1,363 & 63 & 21 , & 1,286 & 1,060 & 171 & 0.13 \\
\hline achuset & & 3,719 & 296 & 12,5 & 31,588 & 118 & 3,995 & 1.07 \\
\hline igan. & . & 3,055 & 339 & & 19 & 157 & & 1.05 \\
\hline Minnesota & & 2,280 & 265 & 8,600 & 11,852 & 192 & 1,951 & 0.86 \\
\hline Mississippi & 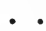 & 1,952 & 97 & 20,130 & 1,141 & 1,711 & 140 & 0.07 \\
\hline Missouri . & & 3,411 & 329 & 10,3 & 14,177 & 241 & & 0.63 \\
\hline $\tan a$ & & 459 & 85 & & & 72 & 1,306 & 285 \\
\hline raska. & & 1,271 & 216 & & & 357 & 430 & 0.34 \\
\hline Nevada . . & & 107 & 27 & & 2,2 & 47 & 440 & 4.11 \\
\hline New Hamps & & 443 & 70 & 6,330 & 3,578 & 124 & 430 & 0.97 \\
\hline
\end{tabular}

${ }^{10}$ The table has been compiled from data obtained from the annual reports of the Third Assistant Postmaster-General, and of the Board of Trustees of the postal savings system. Population figures used were the official estimates for the end of the fiscal year 1916.

${ }^{11}$ Population of 1910. 


\begin{tabular}{|c|c|c|c|c|c|c|c|}
\hline \multirow[b]{2}{*}{$\begin{array}{c}\text { States } \\
\text { AND } \\
\text { TERRITORIES }\end{array}$} & \multirow{2}{*}{ 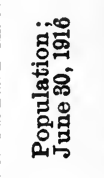 } & \multicolumn{2}{|c|}{ SAVINGS BANKS } & \multicolumn{2}{|c|}{ DEPOSITORS } & \multicolumn{2}{|c|}{ DEPOSTTS } \\
\hline & & 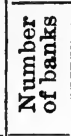 & $\begin{array}{l}\text { Popula- } \\
\text { tion per } \\
\text { bank }\end{array}$ & 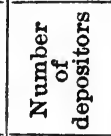 & 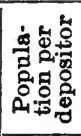 & 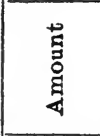 & 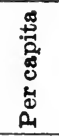 \\
\hline & $\left(\begin{array}{c}(000 \\
\text { omitted })\end{array}\right.$ & & & & & $\begin{array}{c}(000 \\
\text { omitted })\end{array}$ & \\
\hline New Jersey & 2,948 & 200 & 14,740 & 22,762 & 130 & 2,806 & 095 \\
\hline New Mexico & 410 & 47 & 8,724 & 733 & 559 & 112 & 0.27 \\
\hline New York . & 10,273 & 632 & 16,250 & 211,007 & 49 & 27,608 & 2.69 \\
\hline North Carolina & 2,403 & 83 & 28,950 & 425 & 5,655 & 46 & 0.02 \\
\hline North Dakota & 739 & 96 & 7,700 & 424 & 1,743 & 41 & 0.06 \\
\hline Ohio . . . . & 5,150 & 447 & 11,520 & 34,834 & 148 & 5,477 & 1.06 \\
\hline Oklahoma & 2,202 & 200 & 11,010 & 2,556 & 861 & 322 & 0.15 \\
\hline Oregon. & 836 & 134 & 6,240 & 10,472 & 80 & 1,558 & 1.86 \\
\hline Pennsylvania & 8,522 & 566 & 15,050 & 45.579 & 187 & 7,108 & 0.83 \\
\hline Porto Rico . & 1,216 & 44 & 27,640 & 1,770 & 687 & 76 & 0.06 \\
\hline Rhode Island & 614 & 41 & 14,8 & 7,370 & 83 & 796 & 1.30 \\
\hline Carolina & 1,625 & 35 & 46 & 273 & 5953 & 26 & 0.02 \\
\hline South Dakota & 699 & 114 & 6,130 & 556 & 1,127 & 75 & 0.11 \\
\hline Tennessee. & 2,288 & 95 & 24,090 & 1,927 & 1,187 & 261 & 0.11 \\
\hline Texas. : & 4,430 & 357 & 12,400 & 6,908 & 641 & 770 & 0.17 \\
\hline Utah.. & 434 & 35 & 12,400 & 1,570 & 276 & 297 & 0.68 \\
\hline Vermont. & 364 & 56 & $6 ; 500$ & 678 & 537 & 98 & 0.27 \\
\hline Virginia & 2,192 & 111 & 19,750 & 2,935 & 747 & 363 & 0.17 \\
\hline Washington & 1,534 & 165 & 9,300 & 12,963 & 118 & 2,119 & 1.38 \\
\hline West Virginia & 1,386 & 79 & 15,750 & 1,404 & 987 & 252 & 0.18 \\
\hline Wisconsin & 2,500 & 284 & 8,800 & 10,843 & 231 & 1,812 & 0.72 \\
\hline Wyoming & 180 & 33 & 5,450 & 879 & 205 & 168 & 0.93 \\
\hline Total. & 103,514 & $\overline{7,701}$ & 13,440 & 602,937 & 172 & 86,020 & 0.83 \\
\hline
\end{tabular}

States in which the number of the population per depositor is less than 150, and these comprise a solid border of 5 States in the extreme western part of the country, the near-by States of Montana and Colorado, one State in the middle West (Ohio), and 7 States in the East (New York Connecticut, Rhode Island, Massachusetts, New Hampshire, New Jersey and Delaware).$^{12}$ At 12 The District of Columbia also comes in this class. 
the other extreme are 11 States in which less than one-tenth of one per cent of the population are postal savings depositors, and all of these States with the exception of the two Dakotas are south of the Mason and Dixon line, and, with the further exceptions of Arkansas and New Mexico, are east of the Mississippi River.

\section{Distribution of Deposits by States}

The distribution of postal savings deposits by States at the end of the fiscal year 1916 is very similar to that of depositors. The table and map (Map II) point to the following conclusions:

(1) The great bulk of the deposits are in comparatively few States. In only eight of the fiftytwo States and other geographic districts mentioned did the total deposits exceed $\$ 2,500,000$; and these eight States (which in their order were New York, Pennsylvania, Illinois, Ohio, Massachusetts, California, Michigan and New Jersey) held 70 per cent of the total deposits, the first four holding 54 per cent of the total.

(2) Viewed from the standpoint of amount on deposit in proportion to population there is a striking difference in different sections of the country. The amount on deposit per capita varied from $\$ 4.11$ for Nevada to less than 2 cents for South Carolina. 


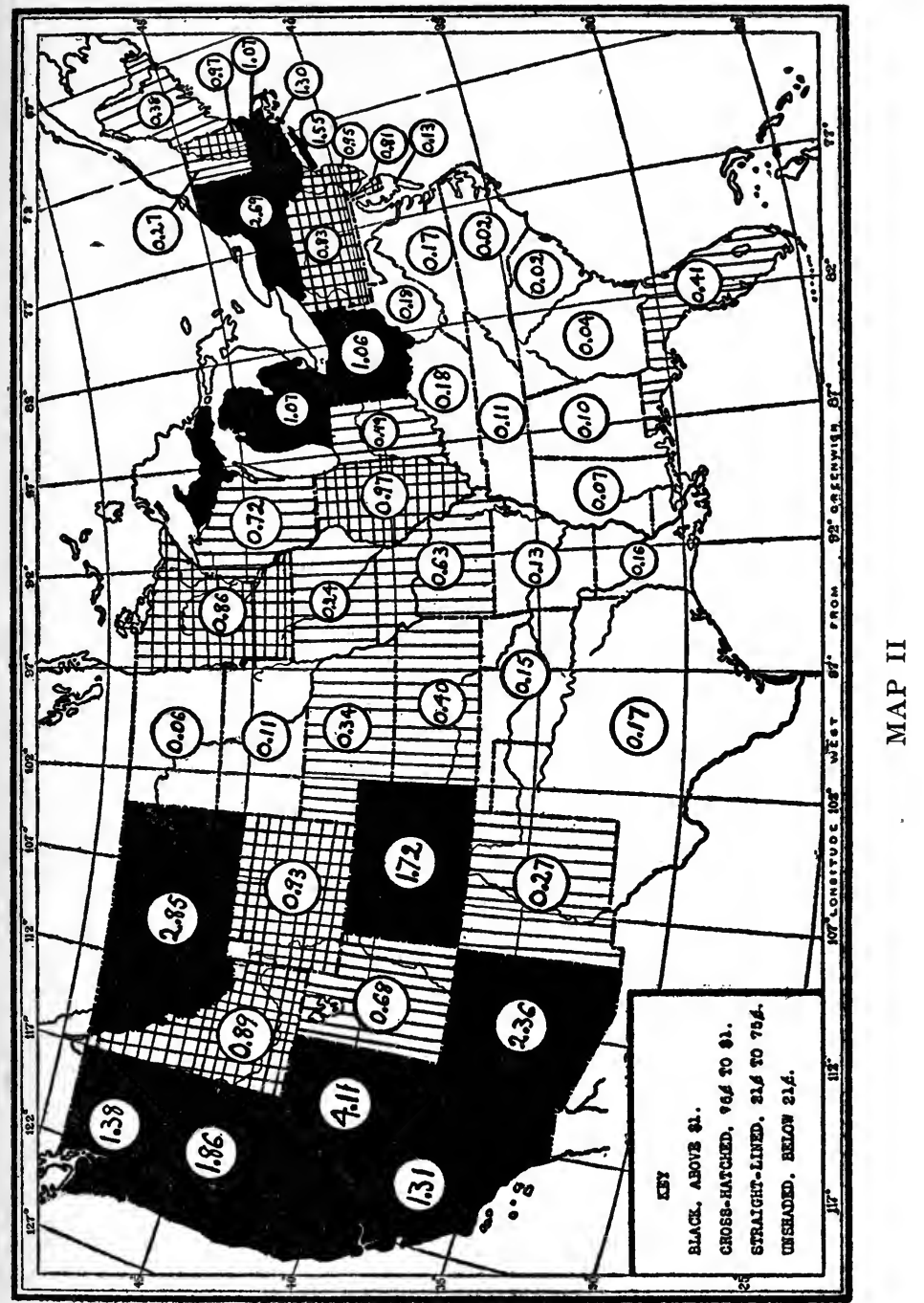


In general it is in the Southern States that the per capita deposits are smallest, and in the mining and lumbering States of the West and the manufacturing States of the East that they are largest. The population of the Dakotas makes scant use of postal savings banks.

\section{Distribution of Deposits by Cities.}

Passing from the distribution of deposits by States to that by cities and towns, we find figures published by the Third Assistant PostmasterGeneral for the places having deposits of over

\begin{tabular}{c|l|c|c}
\hline RANK & \multicolumn{1}{|c|}{ CirY } & $\begin{array}{r}\text { Population }^{13} \\
\text { (000 omitted })\end{array}$ & $\begin{array}{c}\text { Per capits } \\
\text { deposits }\end{array}$ \\
\cline { 1 - 2 } 1 & Leadville, Col. & 8 & $\$ 33.75$ \\
2 & Butte, Mont. & 42 & 19.93 \\
3 & Ironwood, Mich. & 13 & 17.10 \\
4 & Pueblo, Col. & 51 & 5.29 \\
5 & New York City & 5,334 & 4.61 \\
6 & Tacoma, Wash. & 103 & 4.32 \\
7 & Portland, Oreg. & 860 & 4.08 \\
8 & Akron, O. & 546 & 3.94 \\
9 & Detroit, Mich. & 184 & 3.41 \\
10 & Toledo, O. & 116 & 3.40 \\
11 & Bridgeport, Conn. & 237 & 3.39 \\
12 & St. Paul, Minn. & 205 & 3.20 \\
13 & Columbus, O. & 285 & 3.14 \\
15 & Kansas City, Mo. & 89 & 2.76 \\
& Duluth, Minn. & & 2.73 \\
\hline \hline
\end{tabular}

${ }^{13}$ The populations used in compiling these per capita figures were in each case those for the latest date for which official estimates were available, and this means for all the cities except Leadville, Col., and Ironwood, Mich., the populations as of June 30,1914; for the latter two cities the figures are for the census year 1910 . 
$\$ 100,000$ on June 30, 1916. These places were 76 in number. ${ }^{14}$ According to the census of 1910, they had a population of 20.6 millions, or 22 per cent of the total population of the country. They had, however, 397,776 postal savings depositors, or 66 per cent of the total; and these depositors had to their credit 57.3 millions of dollars, or 67 per cent of the total deposits. Analyzing the figures by cities and limiting ourselves to cities with total deposits of over $\$ 200,000$, we find the first 15 cities ranked in the order of their per capita deposits as shown in the table on page 72.

Some of the cities and towns whose total deposits were less than $\$ 200,000$ had very large per

\begin{tabular}{c|l|c|c}
\hline \hline RANK & City or TowN & $\begin{array}{c}\text { Population } \\
\text { in 1910 } \\
(\text { OOO omitted })\end{array}$ & $\begin{array}{c}\text { Per capita } \\
\text { deposits }\end{array}$ \\
\hline 1 & Roslyn, Wash. & 3.1 & $\$ 40.72$ \\
2 & Bisbee, Ariz. & 9.0 & 21.48 \\
3 & Globe, Ariz. & 7.1 & 14.18 \\
4 & Franklin, Pa. & 9.8 & 13.97 \\
5 & Astoria, Ariz. & 9.6 & 13.96 \\
6 & Barberton, O. & 8.4 & 12.41 \\
7 & Hibbing, Minn. & 10.1 & 12.34 \\
9 & Anaconda, Mont. & 14.7 & 11.86 \\
10 & McKees Rocks, Pa. & 16.8 & 11.28 \\
\hline \hline
\end{tabular}

${ }^{14}$ Brooklyn and Long Island City I have included in New York City, although they are given separately in the government figures. See Ann. Rep. 3 Assist. PostmastGen., 1916, p. 35.

${ }^{15}$ Doubtless some of these places have had important 
capita deposits. Figures for ten of these cities are given in the table on page 73 .

It is obviously to the small mining and industrial towns with their large foreign born populations that the postal savings system is rendering its greatest service.

Sizes of Individual Deposits and Deposit Balances and Sources from Which Draron

It has already been mentioned that the Postal Savings act of 1910 limited the balance that any depositor could have (exclusive of interest) to $\$ 500$, and limited the amount which he could deposit in any one calendar month to $\$ 100$. With these restrictions in mind, we may consider the sizes of individual deposits and deposit balances and the sources from which they have been drawn.

The Post Office Department publishes no figures showing the grouping of deposit balances according to size-information which it is desirable that the official statistics should furnish; but from its published statements a small amount of light on the sizes of individual balances can be gained. The average size of the deposit balances at the end of each of the six fiscal years during

changes in their population figures since the census of 1910; and the actual population figures for June 30,1916, if available, would show in some cases materially different per capita figures. 
which the system has been in operation was as follows:

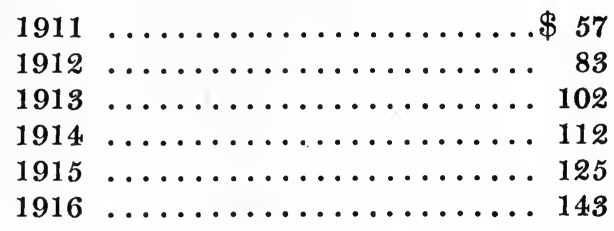

While this shows a healthy increase in the average balance, it throws little light upon the sizes of the items that make up these averages. Third Assistant Postmaster-General Dockery said, December 4, 1915: "We have now more than 30,000 depositors who have reached the limit-who have deposited all they are permitted to deposit under the postal savings law-and 22,000 of the 30,000 who have reached the limit of deposits are foreign born."16 This was exclusive of the deposits which had been withdrawn for investment in $2 \frac{1}{2}$ per cent postal savings bonds. On the other hand, the facts previously noted ${ }^{17}$ - that on June 30, 1916, there were 259 postal savings banks each having only one dollar on deposit, and 447 whose deposits ranged between $\$ 2$ and $\$ 10$-are evidence of a large number of petty accounts.

From the earliest agitation for a postal sav${ }^{16}$ The U. S. Post. Savs. Sys. p. 8.

${ }^{17}$ Page 55. 
ings system in the United States, the debate over the advisability of such a system, as we have seen, has centred largely in the question of the sources from which postal savings deposits would be derived.

Bankers almost unanimously opposed postal savings banks, chiefly because they feared that the funds for postal savings deposits would be withdrawn or diverted from the banks. The proponents of postal savings, on the other hand, claimed that the funds would come chiefly from hoards, from increased savings and from the deposit of funds which otherwise would be sent by the foreign born to the banks of Europe. Obviously it is impossible to describe in any quantitative way the sources from which the deposits have come. That is a topic of information which postal savings bank depositors - a proverbially distrustful class-naturally guard jealously. Such information as we have on the subject comes chiefly from the direct observations of postmasters and others actively engaged in the administration of the postal savings system, and from the testimony of bankers themselves as to the competition which they have experienced from postal savings banks.

In the first place it may be said that there is no evidence whatever that the postal savings sys- 
tem has been to any appreciable extent a competitor of the banks. On the contrary it has been a feeder for the banks, and has been a positive influence for the encouragement of thrift, in the interest of which the American Bankers Association has for some time been conducting a vigorous and well organized campaign. This fact has of late been generally admitted by the very bankers who formerly opposed the establishment of the postal savings system. For example, Mr. Edward L. Robinson, vice-president of the Eutaw Savings Bank of Baltimore, and chairman of the Committee on Postal Savings Bank Legislation of the Savings Bank Section of the American Bankers Association, in a recent address before the Savings Bank Section of the American Bankers Association, after referring to the "almost unbroken front of opposition from the banking interests" to postal savings legislation prior to 1910, said: "[After the system had gone into operation] it was at once evident that the system was not invading the territory occupied by other banks, but was actually drawing money out of hiding places and was making a strong and successful appeal, as was predicted, to the distrustful foreign element." ${ }^{18}$

${ }^{18}$ Com. \& Fin. Chron., A. B. A. Conv. Suppl., Oct. 14, 1916, pp. 184-185. 
Mr. Carter B. Keene, Director of Postal Savings, informs me that the opinion of postmasters throughout the country, as revealed by their letters and reports, is almost unanimous in the conclusion that the great bulk of the deposits come from hoards, and from funds that formerly were sent abroad for deposit in the postal savings banks and other banks of Europe. The tarnished condition of much of the coin deposited, and the receptacles in which the money is brought for deposit, show that much of it has been buried or otherwise hoarded for long periods. Director Keene said in an address before the American Bankers Association Convention in Boston in October, 1913: "A systematic canvass was once made by the Department to ascertain where the postal savings deposits were coming from, and no depositor was found who had transferred his account under normal conditions from a bank to the post office. On the contrary our files are full of reports from postmasters who explain the falling off of deposits by the fact that accounts are being transferred to local banks, and letters from bankers urging the extension of the service to points where they are unable to reach hoarded savings are now too frequent to occasion comment. The postal savings system is a fitting school for other savings institutions. Our de- 
positors are at first more concerned for the security of their savings than in what they may earn. They are thinking of the principal not the interest, and it is only after they have learned the rudiments of saving that the interest feature attracts them. ... The banks then get the accounts." 19

Concerning the inroads made by the postal savings system into the former expensive practice of buying money orders payable to one's self as a means of securing Government custody for savings, Third Assistant Postmaster-General Dockery said in his annual report for 1915: "The use of the postal money order service for savings purposes, in the absence of a postal savings system in this country, was quite general in the years preceding 1911, it having been ascertained that the value of money orders so purchased at first and second class offices during 12 months prior to March 1, 1908, was in excess of $\$ 8,000$,000. These investments were made solely because of the security afforded moneys so intrusted to the Government. With the establishment of the postal savings system ... the money orders purchased for savings purposes were gradually cashed and the use of the money order service for this purpose thereafter was negligible."20

${ }^{19}$ Com. \& Fin. Chron., A. B. A. Conv. Suppl., Oct. 18, 1913, p. 195.

20 Report, p. 15. 
In this connection the experience of six years of postal savings should be described with reference to the fear early expressed that the existence of postal savings banks would encourage runs on the banks in times of great financial distrust. With such depositories for the safe keeping of money everywhere available, it was urged, the timid would withdraw their deposits from banks on the slightest provocation and deposit them at the post offices. ${ }^{21}$

Opponents of postal savings said that the difference between the interest paid by the postal savings bank and that paid by the other banks would be a matter of slight consequence in times of panic, safety of deposits being the great desideratum; and that the accessibility and safety of postal savings banks would encourage excessive withdrawals from other banks. The money

${ }^{21}$ In 1893 there were runs on the postal savings banks in France, as a result of charges that the people's money was being sunk in the building of the Panama Canal. Economist, LI, p. 127. There were also runs a few years ago on some postal savings banks in England, because a political speaker made the assertion that the whole of the postal savings bank deposits had been lost in the South African War. Bankers' Magazine (London), LXXXII, p. 402.

During the crisis in England at the outbreak of the European War, when the joint stock banks remained closed from August 3 until August 7, the postal savings banks remained open, and did not suffer seriously from withdrawals. A. M. Keynes, War and the Financial System, Economic Journal, Sept., 1914, p. 473. 
so withdrawn, it was said, would not flow back quickly to the local banks, because the postal savings bank law required local banks to pledge as security for the deposit of postal savings funds high grade securities supported by the taxing power. How could the banks in times of panic obtain money to purchase such securities?

The advocates of postal savings did not take such a gloomy view. In fact they declared that postal savings banks would strengthen the financial situation in times of panic. That at such times the public might withdraw money from other banks and deposit it in postal savings banks they conceded, but they said this money, as soon as it was deposited in a postal savings bank, would be redeposited by the latter in a local bank. The net result would be that the money withdrawn by timid depositors would not be hoarded, as formerly, but would be returned promptly to the local banks whence it came. From the depositor's point of view the result would be a loss of interest but the securing of a virtual Government guaranty of his deposit. The local banks would have the same money they had before, only the Government would be the depositor at $2 \frac{1}{2}$ per cent interest, instead of the individual at a presumably higher rate. The alleged difficulty of securing, in times of panic, 
satisfactory collateral to pledge for deposits of postal savings bank funds, it was averred, would be mitigated by the facts that the range of securities allowed by law is very wide and that many banks would be owners of acceptable securities, while others could borrow such securities. Apprehension that large sums of money would suddenly be withdrawn from other banks for redeposit in postal savings banks in times of panic was said to be in some degree lessened by the following considerations: (1) many of the most timid depositors, especially the foreign born, would keep their accounts in the Government banks; (2) banks receiving saving deposits generally reserve the right of requiring notice of $\mathbf{3 0}$ days or more for the withdrawal of any considerable sums; (3) no one was to be permitted to deposit more than $\$ 100$ in any one calendar month in a postal savings bank nor to have a deposit balance (exclusive of interest) of more than $\$ 500$.

Since the enactment of the Postal Savings Bank act there has been no national financial crisis of a character to put this question to a severe test. The crisis of August, 1914, was not one that reached the masses of the people. Up to date there have been very few instances recorded in which money has been withdrawn in any considerable amount from banks, in time of stress, 
for deposit in postal savings banks; and most of these instances occurred in towns where confidence in local banks was dealt a blow by the failure of one of their number. Four cases of this kind were described in a statement prepared by the Post Office Department and printed in the Congressional Record of December 15, 1913. ${ }^{22}$ The cities were Ironwood, Mich., Lowell, Mass., McKeesport, Pa., and Pittsburgh, Pa. It will be sufficient to quote from the description of the last case, which was typical. The FirstSecond National Bank of Pittsburgh, Pa., was closed on July 7, 1913. The postal savings receipts for the week beginning on the day of the failure were $\$ 19,624$, a larger sum than had been deposited in an entire month. The postmaster, in commenting on the situation July 17, said: "Very many of the depositors wanted to leave large sums, ranging from $\$ 1,000$ to $\$ 9,000$. Some persons who came to the office when they learned that only $\$ 100$ could be accepted did not open an account. While no record was kept of the amount offered and refused, there is no doubt but what the aggregate was in excess of $\$ 100,000 . "$

Cases were also reported of two bank runs which led to a considerable offering of funds at the postal savings banks. One was in Youngs-

${ }^{22}$ Pages 926, 927. 
town, Ohio, in August, 1913, and the other was the case of the United States Trust Company in Washington, D. C., November 21, 1913. This last run persisted from noon of one day till noon of the next. "During the six days prior to the run thirty postal savings accounts were opened in the Washington post office and $\$ 3,413$ was received. In five days after the run 147 accounts were opened and $\$ 15,650$ was received, and during this period $\$ 24,261$ was rejected on account of the monthly limitation." 23

In all of the above instances of the withdrawal of funds from local banks the money withdrawn was immediately redeposited by the postmaster in local banks, and in most, if not all, of the cases, existing local depository banks for postal savings funds already had deposited with the Government a sufficient margin of collateral to qualify at once for the new deposits.

The severance of diplomatic relations with Germany, February 3, 1917, caused some alarm among foreign born depositors in a few cities lest their postal savings deposits might be seized by the Government in the event of war. Withdrawals increased temporarily at a few post offices. Apprehension as to the safety of postal savings deposits was effectively allayed by the ${ }^{23}$ Ibid., p. 927. 
following announcement of the State Department on February 8: "It having been reported to him that there is anxiety in some quarters on the part of persons residing in this country who are the subjects of foreign states lest their bank deposits or other property should be seized in the event of war between the United States and a foreign nation, the President authorizes the statement that all such fears are entirely unfounded. The Government of the United States will in no circumstances take advantage of a state of war to take possession of property to which international understandings and the recognized law of the land give it no just claim or title. It will scrupulously respect all private rights alike of its own citizens and of the subjects of foreign states."

Limitations on the Size of Deposits and Deposit Balances

This brings us to the question which has given rise to the most discussion since the enactment of the law of 1910: that of the desirability of raising or removing entirely the limitations imposed upon the amount that can be deposited by a depositor in any one month, and upon the total balance which a depositor can have to his credit. The limitations imposed by the act of 1910, 
namely, $\$ 100$ as the maximum amount that could be deposited by any depositor in a month, and $\$ 500$ and accumulated interest as the maximum balance which a depositor could have, soon proved to be onerous, and a number of bills were early introduced in Congress looking toward lightening them. The first of these bills to come into prominence was the Moon bill, ${ }^{24}$ which contained provisions amending the organic postal savings act in a number of important particulars, one of which-the most controverted one-was concerned with changes in these limitations. The bill as originally introduced provided for the removal of all limitations upon the amount that any person could deposit in a postal savings bank at any time and upon the balance he could have to his credit, but limited the amount upon which he could draw interest to a maximum of $\$ 1,000$. The privilege of making non-interest bearing deposits in postal savings banks, in unlimited sums, above the maximum upon which interest is allowed, is granted in a number of countries, notably Italy, Sweden, the Netherlands and its colonies and the Philippines. ${ }^{25}$ The Moon bill

${ }^{24}$ H. R. 7967 of the 63 Cong., introduced September 6, 1913, by Representative Moon of Tennessee.

${ }^{25}$ In Belgium there is no limit to the amount which can be kept on deposit, at interest, but when the deposit balance exceeds 3,000 francs the interest rate on the whole balance is reduced from 3 per cent to 2 per cent. 
took the course through Congress usually taken by important bills which ultimately receive Congressional approval. It was debated at intervals from December 15, 1913, to August 28, 1914, was amended in the House and in the Senate, referred to a conference committee by which the differences were compromised, and was finally passed by Congress at the end of August. In its final form the bill removed the limitations on the amount that could be deposited by a person in any month, left the maximum interest bearing deposit \$500, and authorized the Board of Trustees in its discretion to "accept additional deposits not to exceed in the aggregate $\$ 500$ for each depositor, but upon which no interest shall be paid." The bill was sent to the President for his signature September 1, but was vetoed by him because of one of its provisions authorizing the deposit of postal savings funds in banks not members of the Federal reserve system. "With most of the provisions of the bill" the President in his veto message declared himself "in hearty accord."

Inasmuch as two years later legislation providing for the lightening of the restrictions upon postal savings deposits was passed, and as the chief debate over the question of policy occurred

${ }^{26}$ House Doc. No. 1162, 63 Cong., 2 Sess. This document contains the bill and the President's veto message. Cf. infra, pp. 114-115. 
in connection with the above mentioned vetoed bill, it will be well to summarize briefly at this point the arguments advanced, during the various Congressional debates (1913-1916), on both sides of the question.

\section{Arguments for Lightening Limitations on Deposits}

The chief arguments advanced in favor of the change were as follows:

1. The presumption is in favor of freedom from artificial restrictions in such a matter as permitting the public to deposit its savings in any legally authorized and safe agency for receiving deposits. In the original legislation the restrictions were imposed to protect banks from what many feared would prove a dangerous competition when the postal savings banks were opened. The fact that experience showed that the bulk of the postal savings deposits had come out of hoards and from persons who were not depositors at all in the regular banks made it clear that the raison d'être of the limitations was not a sound one, and that they should be removed, or, at least, greatly lightened. It may be pointed out in this connection that there are usually no legislative limitations on the size of interest bearing savings accounts in commercial banks, and 
that the few such limitations which existed in the case of mutual and stock savings banks during the period of this controversy were more liberal than the existing postal savings act, and, with the exception of Massachusetts, more liberal than those proposed in the original Moon bill. ${ }^{27}$

2. The second argument was that the restrictions were not only resulting in the keeping in hoards of the millions of dollars of savings of postal savings depositors which were in excess of the $\$ 500$ maximum, but also of many millions more representing the savings of persons who would deposit nothing in the postal savings banks if they could not deposit all. It has been previously pointed out that in 1915 more than 30,000 depositors had reached the $\$ 500$ limit, and that of this number 22,000 were foreign born. The Postmaster-General said in his annual report for 1913: "A conservative estimate indicates that more money has been refused by the postal savings system than has been accepted." ${ }^{28}$ Director Weed of the postal savings system in 1913 stated it as his belief that not less than \$30,-

${ }^{27}$ A table showing by States the statutory restrictions on the amount that savings banks may receive from depositors is published in the Cong. Rec. for Aug. 28, 1914, p. 14,382. Of the 48 States (and the District of Columbia) 36 had no restrictions whatever, and three of the others merely authorized the banks to impose restrictions if they should desire.

${ }^{28}$ Page 27. 
000,000 in postal savings deposits had been turned away because of the $\$ 500$ limit. "Sums as large as $\$ 25,000$," said he, "have been brought to us in old tea kettles, stockings, and what not else in the way of queer receptacles, and when we had to refuse to receive more than $\$ 500$ it went back into the nooks and corners, cellars, and underground, where it came from." ${ }^{29}$ Third Assistant Postmaster-General Dockery told the writer that it was the testimony of postmasters throughout the country, over and over again, that if a foreigner could not deposit his entire savings at once he commonly refused to deposit any. ${ }^{30}$

3. A third argument related to the expenses of administering the system. During the first two years the postal savings system was run at a heavy loss to the Government-a loss computed at about $\$ 1,000,000$ down to December, $1913 ;^{31}$ but since that time the records of the system have shown a net profit for each year. The Post Office Department took the position that if the limitations on deposits could be removed or greatly lightened, and particularly if non-interest bearing deposits could be authorized, the deposits

${ }^{29}$ Quoted in the New York Evening Post, Feb. 13, 1913.

${ }^{30} \mathrm{Cf}$. on this subject The U. S. Post. Savs. Sys., pp. 41-51.

${ }^{31}$ Cong. Rec., Dec. 15, 1913, p. 923. 
would be greatly increased, to the great relief of the deficit.

Arguments Against Removal or Lightening of Restrictions on Deposits

1. During the debates in Congress concerning alterations in the restrictions on postal savings deposits, the argument in the opposition that played the chief rôle, an argument which underlay many of the others, was that the changes proposed would make the postal savings system a stronger competitor of existing banks. There was a great deal of opposition on the part of bankers for this reason, and the banking community made its opposition felt in Washington.

It was claimed that, even if the postal savings system had not been a competitor of the banks under the existing limitations on deposits, it did not follow at all that it would not become a competitor when the limitations were lightened or removed. Senator Weeks, of Massachusetts, feared that the raising of the limits would put the postal savings system into competition with the mutual savings banks of the East, ${ }^{32}$ and Senator Lodge, of Massachusetts, thought that the proposals were a move in the direction of putting the Government into competition with the banks in

${ }^{32}$ Cong. Rec., April 14, 1914, p. 6672. 
the savings bank business. ${ }^{33}$ Senator Gallinger, of New Hampshire, had received letters from officials of the savings banks in his State making a very earnest protest against the House proposal that there should be no limit on non-interest bearing deposits. ${ }^{34}$

2. A second objection was the claim that the raising of the deposit limit and particularly the allowance of large or unlimited non-interest bearing deposits would open the door to the fraudulent evasion of debts and taxes. According to a decision of the Attorney-General's office, deposits in postal savings banks are exempt from attachment and execution for debt. In December, 1915, and during the consideration of the bill to raise the limit of interest bearing deposits to $\$ 1,000$ and to authorize non-interest bearing deposits up to another thousand dollars, Representative Steenerson, of Minnesota, drew a picture of a man with a wife and five or six children over ten years of age, each depositing $\$ 2,000$ in the postal savings bank, and escaping creditors to the total amount deposited..$^{35} \mathrm{He}$ raised the question whether a lower limit than the one proposed should not be fixed for minors,

${ }^{33}$ Ibid., April 15, 1914, p. 6727.

${ }^{34}$ Ibid., April 14, p. 6670; and April 15, p. 6725. p. 618 .

${ }^{35}$ Cong. Rec., Dec. 17, 1915, p. 433; and Jan. 6, 1916, 
but did not urge the point, for he admitted that the evidence so far available was that minors were not using the postal savings banks very extensively, and that comparatively few of those who did use it would have deposits of over $\$ 1,000$. Senator Smoot, of Utah, in the course of debate on the earlier bill, said there was one class of people who would go to the limit of $\$ 2,000$. "I have received a number of letters," he said, "stating that there were people who used the postal savings banks, depositing their money in the post offices of the country, with the purpose of preventing the money from being garnisheed; .... and they felt perfectly safe about keeping it from their creditors." 36 Senator Sherman, of Illinois, said that he also had received many complaints on this subject from a great variety of people. ${ }^{37}$

Postal savings deposits, being debts of the United States Government, are exempt from taxation under Section 3701 of the Revised Statutes, which provides that "all stocks, bonds, treasury notes and other obligations of the United States shall be exempt from taxation by or under State or municipal or local authority." Senator Hitchcock, of Nebraska, thought that

${ }^{36}$ Ibid., April 27, 1914, p. 7303.
${ }^{87}$ Ibid., April 27, 1914, p. 7303. 
the bill, if passed, would encourage tax dodging through the withdrawal of money from ordinary banks just before assessment day and its temporary deposit in postal savings banks. ${ }^{38}$

The tax dodging argument apparently did not make a very strong appeal. The fact that the interest rate proposed to be paid by the Government was but 2 per cent on the first thousand dollars, and nil on the second, the proposed limitation to $\$ 2,000$ on the total amount that could be deposited, the ease with which a would-be tax dodger could dodge taxes on cash funds without recourse to postal savings deposits, and the fact that Federal, State and city bonds paying higher interest rates than postal savings deposits were exempt from taxation-all of these facts weakened decidedly the appeal of the tax dodging argument.

As to the argument that the raising of the deposit limits would encourage evasion of debt, the proponents of the higher deposit limit argued that there had been very little evidence of such evasion under the old limits, and that the new ones were not high enough to make the danger a serious one. Furthermore, said Senator Bryan, of Florida, who was sponsor for the bill in the Senate, the question whether the additional de${ }^{38}$ Ibid., p. 7304. 
posits authorized by the proposed legislation should be exempted from attachment for debt and from taxation is a separate question to be considered by itself. ${ }^{39}$ Such rights of exemption were not an essential part of the proposal to raise the deposit limits.

3. A third argument in opposition was urged by Senator Weeks of Massachusetts. It may best be stated in his own words: "I feel perfectly sure that if this is undertaken you will see men from time to time dropping into the country post office and depositing their money where the postmaster has no facilities for caring for it, having no safe or any other means of protecting deposits. ... [They will do so] not for the purpose of saving the money, not for the purpose of getting interest on it, but simply for the purpose of leaving it there for safe keeping until it is wanted."40

These were the only arguments worthy of mention advanced in the Sixty-third and Sixty-fourth Congresses, on either side of the broad question of raising the deposit limits.

\section{Limits on Deposits Raised in 1916}

As previously noted, the veto by President Wilson of the Postal Savings bill of 1913-14 39 Ibid., April 28, 1914, p. 7360.

40 Ibid., April 27, 1914, p. 7302. 
(H. R. 7967) had no reference to the provisions of the bill raising the limits on deposits. In the next session of Congress a new bill providing for the raising of the limits was introduced by Representative Moon. By this time the Postal Savings Bank Legislative Committee of the Savings Bank Section of the American Bankers Association had withdrawn its opposition to the legislation. ${ }^{41}$ With the bankers' organized opposition removed, the proposed legislation had fairly clear sailing, and the bill (H. R. 562) became law by the signature of the President on May 18, 1916. The new act repealed the provision of the organic law which imposed a limit of $\$ 100$ on the amount that could be deposited in one calendar month, raised the interest bearing limit from $\$ 500$ to $\$ 1,000$, and provided "that the Board of Trustees may, in their discretion, and under such regula-

${ }^{41}$ The committee reported to the Savings Bank Section of the American Bankers Association, September 7, 1915: "It is understood that the Sixty-fourth Congress will enact legislation raising the limit of interest bearing deposits to $\$ 1,000$ and giving discretionary powers to the Board of Trustees to accept an additional $\$ 1,000$ without interest. From the knowledge acquired by your committee in its efforts to have the original Moon bill amended, and from a frank interchange of views with the Director of the postal savings system, we feel that the desire of the trustees for this increase of authority is not unreasonable and will not work any hardship upon our savings banks. . ." Com. \& Fin. Chron., A. B. A. Conv. Suppl., Sept. 18, 1915. p. 181. 
tions as such board may promulgate, accept additional deposits not to exceed in the aggregate $\$ 1,000$ for each depositor, but upon which no interest shall be paid."

Notwithstanding the efforts that were made by the post office authorities to have this latter permissive legislation passed, and the strong case that was made in its favor, the trustees have not yet seen fit to exercise the authority therein granted to receive non-interest bearing deposits up to $\$ 1,000$. The writer has been unable to obtain any official explanation of their inaction. Director Keene of the Division of Postal Savings, referring to the matter in an address at the American Bankers Association Convention, September 26, 1916, merely said, "The Board of Trustees has not thus far accepted the non-interest bearing accounts." 42

The Third Assistant Postmaster-General in his annual report for 1916 (dated September 30), after saying that the previous limitations "greatly retarded the growth of the system and restricted the scope of its usefulness," refers to the amendment as follows: "By the terms of the amendment a person may now deposit any number of dollars, and at any time, until the balance to his

${ }^{42}$ Com. \& Fin. Chron., A. B. A. Conv. Suppl., Oct. 14, 1916, pp. 191-192. 
credit amounts to $\$ 1,000$. The effect of the liberalizing legislation was an immediate and pronounced increase in postal savings deposits. As the advantages of the new law become known the accumulated hidden savings of the country flow to the postal banks and are there restored to the circulating medium." ${ }^{43}$ In its annual report dated December 1, 1916, the Board of Trustees uses almost the same language. Both reports strangely ignore the question of receiving non-interest bearing deposits.

\section{Growth of Deposits}

Since the inauguration of the postal savings system on January 3, 1911, the growth of deposits has been continuous, and this growth (as just noted) has recently been stimulated by the raising of the limitations and by conditions created by the European War. Laborers in the United States have been very prosperous during the past two and a half years, and the situation in Europe has not been favorable to the sending of money across the water for safe keeping. The following figures show the balances on deposit in the postal savings banks at the end of each fiscal year since the system was inaugurated.

${ }^{43}$ Ann. Rep. 3 Assist. Postmast.-Gen., 1916, p. 7. 
Table 4

Growth of Postal Savings Deposits, 1911-1917

\begin{tabular}{c|c|c}
\hline $\begin{array}{c}\text { Fiscal year ending } \\
\text { June } 30\end{array}$ & Amount & $\begin{array}{c}\text { Percentage increase } \\
\text { over preceding date }\end{array}$ \\
& & \\
1911 & $(000$ omitted $)$ & \\
1912 & 20,237 & 2900 \\
1913 & 33,819 & 67 \\
1914 & 43,444 & 28 \\
1915 & 65,685 & 51 \\
1916 & 86,020 & 31 \\
June 1, 1917 & $131,500$. & 26 \\
\hline
\end{tabular}

Interest Paid on Postal Savings Deposits

The act of 1910 provided that "interest at the rate of 2 per centum per annum shall be allowed and entered to the credit of each depositor once in each year, the same to be computed on such basis and under such rules and regulations as the Board of Trustees may prescribe; but interest shall not be computed or allowed on fractions of a dollar." Although interest rates prior to the European War ruled higher in the United States than in most advanced countries, this rate of 2 per cent is the lowest one to be found in any postal savings system in the world.

In framing rules and regulations concerning the payment of interest to depositors the Board of Trustees has been very exacting. It early

${ }^{44}$ Sec. 7. 
decided that compound interest should not be allowed. A depositor, however, may withdraw interest payable, and then immediately redeposit it as principal. This ruling of the board seems petty. Remembering the legal limitations on maximum deposits, and the provision of the law that interest cannot be paid on fractions of a dollar, it is difficult to see justification for this unusual ruling against compound interest. That it is an item of considerable importance will be seen from the fact recently cited by the Third Assistant Postmaster-General, that interest allowed depositors from the beginning of the postal savings system to August 31, 1915, amounted to $\$ 1,467,604$, of which amount $\$ 877,412$ had been applied for and paid by postmasters, and the remainder, $\$ 590,192$, had not yet been applied for, ${ }^{45}$ and consequently was not drawing interest. The hardship which this ruling works has become greater since the interest-bearing limit was raised from $\$ 500$ to $\$ 1,000$.

A second ruling, and one of much more serious moment to depositors, is that no interest shall be paid on money which remains on deposit for less than a year, and no interest shall be allowed for fractions of a year even after the money has been on deposit a full year. There is a certain amount

${ }^{45}$ U. S. Post. Savs. Sys., pp. 13-14. 
of irony in the following quotation from the 1914 annual report of the Third Assistant PostmasterGeneral: "Interest on deposits [of postal savings funds] in banks is computed on the basis of average daily balances. . . . Interest on postal savings certificates is computed on the basis of deposits which have remained for one or more full years from the first day of the month following the month in which the deposits were made." ${ }^{46}$

Furthermore, it has been ruled that a depositor who moves away from the town or city in which his postal savings account is held cannot transfer his account to his new place of residence, before the end of his "deposit year," without forfeiting his accumulated interest. $\mathrm{He}$ can make the transfer only by closing his old account, and opening an entirely new one at his new place of residence. ${ }^{47}$

\section{${ }^{46}$ Report, p. 6.}

47 Third Assistant Postmaster-General Dockery, in a letter to the writer on this subject, dated February 12, 1917, said: ". . . . I have to inform you that no provision is made in the postal savings regulations for the transfer of accounts between depository offices. Provision is made, however, for the transfer of accounts between stations of a depository post office, or between a station and the main office. If a depositor removes to a distant locality, he is not compelled to transfer his account for he may make deposits and withdrawals by mail for such time as suits his pleasure. It is not necessary, therefore, that he should forfeit accumulated 
The amount of interest of which these regulations deprive depositors every year is large. Take the year 1916 for example. The fiscal year began with a balance to the credit of depositors of $\$ 65,684,708$ and ended with $\$ 86,019,885$. The mean deposit balance was therefore $\$ 75,852,296$. At 2 per cent per annum the interest on this sum would have been $\$ 1,517,046$. As a matter of fact, the interest "allowed and entered to the credit of depositors" was but $\$ 964,187$, or 1.27 per cent on the mean annual balance.

On the other hand, aside from the 5 per cent reserve kept with the Treasurer of the United States, the Government deposited practically ${ }^{48}$ all of its postal savings funds in banks at interest at the rate of $2 \frac{1}{2}$ per cent per annum on average daily balances. The interest received on these bank deposits for 1916 was $\$ 1,764,368$. Adding to this the $\$ 34,966$ received on the $2 \frac{1}{2}$ per cent

but as yet undue interest unless he decides to transfer his account to his new place of residence. The Department has recognized, however, that this procedure is sometimes inconvenient, and plans for the transfer of accounts have from time to time been under consideration. The matter is one which seriously affects our present methods of accounting. It is believed that a solution of the problem will soon be reached provided it is deemed advisable, in view of all the circumstances, to adopt a plan for the transfer of accounts."

${ }^{48} \mathrm{~A}$ small amount was invested in $21 / 2$ per cent postal savings bonds, but the entire income of these bond investments for the year 1916 was only $\$ 34,966$. 
bond investments, one arrives at $\$ 1,800,000$ (in round numbers) as the interest earned for the year. This represents an average daily balance, drawing interest, of $\$ 72,000,000 .^{49}$ This sum came entirely from depositors, but for the same period the sum on which interest was allowed and entered to the credit of depositors was but $\$ 48$,209,350 , or 67 per cent of that upon which the Government received interest. Viewed in another way, if the Government had paid its 2 per cent to depositors on the same sum (less the 5 per cent reserve) as that upon which it received its $2 \frac{1}{2}$ per cent it would have paid depositors $\$ 1,516$,000 instead of $\$ 964,187$.

The explanation of the great discrepancy between interest paid and interest received consists chiefly in the fact that depositors forfeit their accumulated interest by withdrawing substantial sums before the end of the year interest period. Third Assistant Postmaster-General Dockery recently cited the following figures relating to this subject before a committee of the United States Senate: "Sixty-two per cent of the deposits are withdrawn before they have been on deposit one year; 53 per cent of the 38 per cent that remains is withdrawn within the second

${ }^{49}$ On this basis the total average daily balance (inclusive of the 5 per cent reserve at Washington) would have been about $\$ 75,800,000$. 
year; and of the 18 per cent that still remains, 48 per cent is withdrawn within the third year, leaving approximately only 9 per cent of the deposits in the custody of the Government at the end of the third year." 50

As a matter of fact the interest rate paid is so low that it makes a very weak appeal to the class of people who deposit in the postal savings banks. Their motive is primarily security. The Government is now realizing large profits from the postal savings system $^{51}$ - for 1916 the estimated profit was $\$ 481,816^{52}$-and this profit is coming from a class of people in the community, the thrifty poor, from whom it is bad social policy to take it. Of course it would be administratively impracticable to pay interest to depositors on average daily balances-no savings banks do that. Would it be expecting too much, however, to ask for our postal savings depositors the allowances of interest on half yearly or even quarterly balances? Moreover, is it unreasonable to ask the Board of Trustees, in view of the nomadic character of our foreign born population which patronizes

${ }^{50}$ U. S. Post. Savs. Sys., 1916, p. 5.

${ }^{51}$ The first two years the system was run at an estimated loss of $\$ 1,000,000$. Since that time every year has witnessed a substantial net profit to the Government.

${ }^{52}$ Board of Trustees, Ann. Rep. Post. Savs. Sys., 1916, (House Doc. No. 1433, 64 Cong., 2 Sess.), p. 61. 
the postal savings system most, to devise a simple system of transfer by which a depositor who is changing his place of residence may transfer his postal savings account without forfeiting his accumulated but as yet undue interest? 


\section{CHAPTER V}

\section{Investment of Postal Savings Funds}

The most difficult problem, it has been said, which Congress had in formulating its postal savings bank plan in 1910 was that of the investment of the deposited funds. This problem, we have seen, ${ }^{1}$ was solved by dividing the funds into three parts: (1) A 5 per cent reserve fund to be kept in lawful money in the Treasury of the United States $;^{2}(2)$ a sum not exceeding 30 per cent of the amount of postal savings funds, which "may at any time be withdrawn by the

1 Supra, pp. 43-44.

2 The 5 per cent reserve held in the United States Treasury at Washington is adjusted only once a year, and, inasmuch as there has been an increase of deposits during each year, the percentage of reserve as adjusted declines throughout the year. With deposits growing as rapidly as those of the postal savings system, such a long interval between the dates of the adjustments of the reserve results in the maintenance of a reserve which averages far below 5 per cent. Probably a 5 per cent requirement is unnecessarily high under the circumstances. If so, it should be reduced by law. To make the percentage of the reserve vary inversely throughout the year, as at present, with the amount of postal savings deposits seems to be a questionable policy. Cf. Ann. Rep. 3 Assist. Postmast.-Gen., 1913, p. 37. 
trustees for investment in bonds or other securities of the United States"; (3) a sum, which normally should not be less than 65 per cent of the total postal savings deposits, to be kept on deposit "in solvent banks, whether organized under national or State laws, being subject to national or State supervision and examination. ...."3

Postal savings funds deposited in banks were to bear interest at a rate of not less than 21 per cent, and the Board of Trustees was to require depository banks to give adequate security for such deposits, in the form of "public bonds or other securities, supported by the taxing power."

\section{Investment in Bonds}

Aside from the purchase of a few postal savings $2 \frac{1}{2}$ per cent bonds $(\$ 1,558,500$ in all down to June 30, 1916) from their holders in order to maintain their parity, ${ }^{4}$ the trustees of the postal savings system have made no purchases of bonds whatever. The banks, despite their early opposition to the system, showed great eagerness in most localities to secure postal savings deposits,

3 The word "bank" was declared by the law (sec. 9) to "include savings banks and trust companies doing a banking business."

${ }^{4}$ Infra, p. 127. 
and from the beginning practically all of the funds were deposited in banks.

The percentage of the total postal savings deposits which had been redeposited and was held in banks at the end of each half year period since the inauguration of the system is as follows: ${ }^{5}$

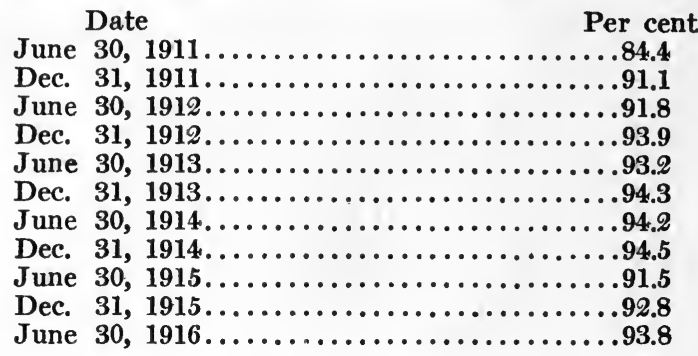

The postal savings amendment of May 18, 1916, therefore, merely recognized the status quo when it repealed the provision of the act of 1910 authorizing the investment of 30 per cent of the deposits in United States securities.

It reenacted the provision authorizing the Board of Trustees to invest all or any part of the postal savings funds, except the 5 per cent reserve fund, in bonds or other securities of the United States, "when in the judgment of the President the general welfare and interests of the

${ }^{5}$ The balances on deposit in banks used in these computations are those shown by the banks' books. At all times there is a small amount of postal savings funds in the hands of postmasters. 
United States so require." Aside from this, the only provisions in the present law for the investment of postal savings funds in United States securities are: (1) That the trustees may so invest any funds which in any State or Territory "shall exceed the amount which the qualified banks therein are willing to receive under the terms of this act, and [when] such excess amount is not required to make up the reserve fund of 5 per centum." This is a contingency which has not yet been met and is not likely to occur.

That the Board of Trustees may in its discretion purchase from the holders $2 \frac{1}{2}$ per cent postal savings bonds. As previously noted, up to June 30, 1916, the trustees had purchased about a million and a half dollars worth of these bonds. If the market rate of interest goes up materially in the near future, and the prospects are that it will, the trustees are likely to be called upon to purchase them in substantial quantities.

\section{Deposit of Postal Savings Funds in Banks}

Soon after the act of 1910 was passed the Post Office Department received applications from all kinds of banks scattered throughout the country for the privilege of becoming depositories of postal savings funds. On December 31, 1910, the Board of Trustees issued its first series of "regu- 
lations for the guidance of banks qualifying as depositories of postal savings funds." The regulations provided that "any solvent bank, whether organized under national or State laws,... subject to national or State supervision and examination" might lawfully qualify as a depository. According to Director Weed, this authorization was limited to incorporated banks or "banks that are clothed with the essential attributes of corporations by virtue of legislative action."' Private banks were all excluded, except a certain class in Indiana which met the requirements as to "organization, supervision and examination." Branch banks were excluded which did not have apportioned to them by the parent bank a specified amount of capital. In a number of states, state banks which could have qualified under Federal law were prevented from doing so by state law, but this was later remedied in most jurisdictions.?

In order to qualify as depositories banks were

${ }^{6}$ Com. \& Fin. Chron., A. B. A. Conv. Suppl., 1912, p. 192.

7 State banks were originally disqualified in Arkansas, California, Kentucky, Massachusetts, Michigan, Mississippi, South Dakota, Tennessee and Wisconsin. By 1916, however, state institutions in all of these states except Arkansas and Mississippi had qualified as postal savings depositories. Cf. Theodore L. Weed, The Postal Savings Banks and the United States, in Com. \& Fin. Chron., A.. B. A. Conv. Suppl., Sept. 21, 1912, p. 192; and Ann. Rep. 3 Assist. Postmast.-Gen., 1916, p. 33. 
required to submit a satisfactory report of condition and to offer proper collateral for the deposits-a subject to be considered later. ${ }^{8}$ Funds were to be apportioned among the qualified banks only on the first day of each quarter. A later regulation provided that the apportionment of deposits to newly qualified banks would only "apply to funds deposited after the date as of which the bank qualified"9 - a regulation that was necessary to avoid the confusion which would result from a complete reapportionment of deposits each time a new bank in the community qualified as a depository.

The number of banks of each class which were qualified as depositories for postal savings funds at the end of each fiscal year since 1912 is as follows : ${ }^{10}$

TABLE 5

Number of Banks Qualified as Depositories, 1913-1916, by Classes.

\begin{tabular}{c|c|c|c|c|c|c}
\hline \hline Year & $\begin{array}{c}\text { National } \\
\text { banks }\end{array}$ & $\begin{array}{c}\text { State } \\
\text { banks }\end{array}$ & $\begin{array}{c}\text { Savings } \\
\text { banks }\end{array}$ & $\begin{array}{c}\text { Trust } \\
\text { companies }\end{array}$ & $\begin{array}{c}\text { Organized } \\
\text { private } \\
\text { banks }\end{array}$ & Total \\
\hline 1913 & 3,786 & 2,405 & 377 & 609 & 49 & 7,226 \\
1914 & $\mathbf{8}, 627$ & 2,099 & 347 & 617 & 25 & 6,715 \\
1915 & 3,628 & 1,499 & 291 & 568 & 21 & 6,007 \\
1916 & 3,547 & 1,257 & 262 & 547 & 21 & 5,634 \\
\hline
\end{tabular}

${ }^{8}$ Infra, pp. 120-125.

${ }^{9}$ Sec. 10 of Regulations of 1913.

${ }^{10}$ Figures have been compiled from the annual reports of the Third Assistant Postmaster-General. 
The tendency of the total number of depository banks to decline is due to a number of causes among which may be mentioned: (1) the plethora of moneyed capital during the past two years, which has made deposits of postal savings funds unattractive to many banks, requiring as they do the pledge of collateral and the payment of $2 \frac{1}{2}$ per cent interest; (2) the discontinuance of postal savings banks in many communities, $;^{11}$ and (3) the legislation discriminating against banks which are not members of the Federal reserve system as depositories. This last item calls for further discussion.

The Federal Reserve act, as originally enacted, contained a clause to the effect that no government funds nor postal savings funds should be deposited in the continental United States in any bank not belonging to the Federal reserve system. ${ }^{12}$ This provision was construed by the Attorney-General to permit the continuance in nonmember banks of postal savings balances already on deposit, but to prevent the making of any further deposits in such banks. ${ }^{13}$ The discontinu-

${ }^{11}$ Supra, pp. 53-54.

12 Sec. 15 of act.

${ }^{13}$ Concerning this subject the Third Assistant PostmasterGeneral said in his annual report for 1915 (p. 12): "No deposits have been made in non-member banks since November 16, 1914, the day the [Federal reserve] system went 
ance of making deposits in non-member banks gave rise to much inconvenience and to an increase in the expenses of administration-evils which non-member banks were not slow to bring prominently before Representatives in Congress. Carter B. Keene, Director of Postal Savings, said the restriction of deposits to member banks "resulted in the elimination of hundreds of State banks. In many instances it was necessary to send funds long distances to places where eligible banks were located. This worked embarrassment in the expeditious and safe administration of the service, and at the same time defeated the dominant thought that controlled the finances of the organic Postal Savings act, that the deposits brought out of hiding should be released for commercial purposes in the identical localities where they originated."14

A number of bills were introduced in Congress providing for the reauthorization of State banks as depositories, and finally a bill (H. R. 7967, 63

into operation. The Attorney-General of the United States has held that the inhibition on depositing postal savings funds in non-member banks applies only to funds available for deposit on and after the date when the system went into operation, consequently withdrawals from non-member banks have not been made except to meet the demands of the service."

14 Com. \& Fin. Chron., A. B. A. Conv. Suppl., Oct. 14, 1916, p. 192. 
Cong., 2 Sess.), whose history has previously been narrated in connection with the discussion of the raising of the limits on deposits, ${ }^{15}$ was passed by both houses of Congress, authorizing deposits of postal savings funds "in solvent banks, whether organized under national or State laws, and whether member banks or not of a reserve bank, ... being subject to national or State supervision and examination. . . ." On September 11, 1914, President Wilson vetoed this bill, and communicated his reasons therefor in a veto message to Congress. ${ }^{16}$ In this message he said:

"When the Federal Reserve act was passed it was thought wise to make the inducement to State banks to enter the Federal reserve system as many and as strong as possible. It was, therefore, provided in that act that Government funds should be deposited only in banks which were members of the Federal reserve system. The principle of such a provision is sound and indisputable. The moneys under the control of the Government ought to be placed only in those banks which are most directly under the supervision and regulation of the Congress itself. It was recognized, also, that the scattering of government deposits in small amounts among too

${ }^{15}$ Supra, pp. 85-87.

${ }^{16}$ House Doc. No. 1162, 63 Cong., 2 Sess. 
large a number of banks would in time of stress be of decided disadvantage to the Federal reserve system, which seeks as much as possible to mobilize the financial resources of the country under one control. The bill which I now return repeals that provision so far as it might apply to funds accumulated in the hands of the Government under the postal savings system. It is in this provision of the bill that I find myself unable to concur.

"It is my clear conviction, very respectfully urged and submitted, that as a matter of principle as well as of policy we should strengthen and safeguard the new banking system very jealously with a view to the ultimate unification of the entire banking system of the country under the supervision of the Federal Reserve Board. It would, in my judgment, be a grave mistake to take away any of the benefits or advantages held out by the present law to member banks to enter the system, and to take them away just as the system is about to be put into operation and the promises of the act of last December made good to the banks that have entered."

A year and a half later, on May 18, 1916, the Postal Savings Amendment act was passed, which contained a compromise between the positions on this subject taken in the bill previously 
vetoed and in the veto message. This amendment, which is the present law, provides that "if one or more member banks of the Federal reserve system . . . exists in the city, town, village, or locality where the postal savings deposits are made, such deposits shall be placed in such qualified member banks substantially in proportion to the capital and surplus of each such bank, but if such member banks fail to qualify to receive such deposits, then any other bank located therein may . . . qualify and receive the same."17 In this connection it is interesting to note that the proportion of the depositories which were national banks was not very much greater on June 30, 1916, than on June 30, 1914, before the Federal Reserve act went into effect, the respective percentages being 63 and 54 .

The first two years experience with depository banks taught some lessons which in the reorganization of 1913 led to certain administrative changes. The most important of these were the abolishment of the cumbersome system of "emergency credits" and the creation of a more efficient method of handling "out of town accounts."

${ }^{17}$ The law as thus amended (sec. 2) has been interpreted by the counsel of the Federal Reserve Board. See Federal Reserve Bulletin, July 1, 1916, pp. 331-332. 


\section{Abolition of Postmasters" "Emergency Credits"}

Each postmaster now as heretofore is instructed to apportion his deposits of postal savings receipts among all the banks in his city or town, which are qualified as postal savings depositories, substantially in proportion to their respective capitals and surpluses. ${ }^{18}$ All of the postal savings funds so deposited are to be entered to the credit of the Board of Trustees of the postal savings system. Prior to July 1, 1913, however, there was one exception to this latter rule, and that was described as follows in the official regulations:

"[This rule applies except for] an amount which will be specified by the board as an emergency credit for use by each postmaster in meeting withdrawals by depositors when he has insufficient funds on hand for such purpose. The

${ }^{18}$ This system which is apparently essential to the meeting of two of the postulates of American postal savings"keeping money at home" and satisfying "competing" banks - often becomes exceedingly cumbersome. Why this is true will be evident when one bears in mind that in most cities and towns the postal savings deposits each day are small, while in a large proportion of places there are several banks among which the postal savings funds must be apportioned. As early as 1912, for example, there were 40 qualified depositories in Chicago, 30 in Philadelphia, 19 in New York, and between 10 and 12 in a number of other cities. Com. \& Fin. Chron., A. B. A. Conv. Suppl., Sept. 21, 1912, p. 191 . 
amount thus fixed will be deposited by the postmaster to his official credit in one of the depository banks especially designated for the purpose, to be subject to his official check as postmaster for the purpose mentioned only, and will be maintained by the postmaster at the amount specified by the Board of Trustees, by means of deposits from his daily postal savings receipts. ... The amount of emergency credit may be added to the regular quota assigned to a depository bank, . . . and shall be subject to interest payment. . . ." "19

That the creation of such an emergency credit account in the name of each postmaster at whose office there was a postal savings bank was making a system already complex doubly so is evident. It gave rise to about 13,000 extra accounts and involved "endless correspondence, bookkeeping, and interest computing details."

The "emergency credit" and all the individual postal savings accounts with banks in the names of postmasters were done away with by the new regulations put in force July 1,1913 . In place thereof the expedient was adopted of designating

${ }^{19}$ Regulations for the Guidance of Banks Qualifying as Depositories of Postal Savings Funds, etc., issued by authority of the Board of Trustees, 1911, p. 6.

${ }^{20}$ Carter B. Keene, The Postal Savings System, Com. \& Fin. Chron., A. B. A. Conv. Suppl., Oct. 18, 1913, p. 196. 
in each place one bank upon which the postmaster was authorized to draw his checks against the postal savings deposit (in the name of the Board of Trustees) each month, to an amount specified, as a provision for emergency needs. ${ }^{21}$

\section{Out of Town Depositories}

Another cumbersome feature of the original plan which was greatly improved in the reorganization of 1913 related to the deposit of funds in banks outside of the local community, when there was no qualified depository bank in the place where the postal savings bank was situated. Originally postmasters in such places had been required to send their postal savings funds by registered mail to the nearest town having a qualified bank or banks, and to apportion their deposits among such banks (when there was more than one) substantially according to their respective capitals and surpluses. Under the new arrangement the postmaster at the place having no qualified banks remits his postal savings funds by registered mail to the postmaster at the neighboring place having qualified banks, and the latter postmaster deposits these funds along with his own postal savings funds, in the proper pro-

${ }^{21}$ Instructions to Postmasters at Postal Savings Depository Offices, 1913, p. 12. 
portion in the various qualified banks. Postmasters at non-banking offices now secure funds for meeting withdrawals of deposits by means of drafts on the postmasters to whom their remittances have been made.

\section{Collateral Security}

The organic Postal Savings act of 1910 provided that the Board of Trustees should take from depository banks "such security in public bonds or other securities, supported by the taxing power, as the board may prescribe, approve, and deem sufficient and necessary to insure the safety and prompt payment of such deposits on demand." 22 Securities acceptable under this provision have been interpreted to be limited to the "general obligations" of the political division issuing them and payable "without restriction or limitation to a special fund from the proceeds of taxes levied upon all taxable real and personal property within the territorial limits of such political division." ${ }^{23}$ Shortly after the outbreak of

22 In the amendment of May 18, 1916, this provision was reenacted; but after the words "other securities" were inserted the words "authorized by act of Congress or." This addition had reference to the agitation for authorizing postal savings funds to be invested in the securities of Federal land banks, the bill for the establishment of which was then before Congress.

${ }^{23}$ Rulings of Board of Trustees, Nov. 18, 1913, as modified by rulings of Nov. 19, 1914. 
the European War the Post Office Department was "virtually swamped" with requests to accept as collateral for postal savings deposits various kinds of temporary securities. In reply to these requests the Board of Trustees, November 19, 1914, adopted the following regulations:

"Obligations of the general class embracing what are commonly known as 'revenue bonds,' 'temporary bonds,' 'temporary notes,' 'certificates of indebtedness,' 'warrants,' and the like obligations, whether issued in anticipation of the collection of taxes, assessments, or other revenues, or of the sale of bonds or other obligations, or for similar purposes, will not be accepted as security for postal savings deposits: Provided, That in applying this regulation, consideration will be given to the legal status of the obligations submitted rather than the nomenclature employed in designating such obligations." 24

Since the reorganization of 1913 the Solicitor for the Post Office Department (designated as the Assistant Attorney-General for the Post Office Department prior to November 9, 1914)

${ }^{24}$ Pamphlet published by Post Office Department entitled, Determining the Legal Acceptability of Bonds Offered as Security for Postal Savings Deposits, 1915. See also Report of the Solicitor for the Post Office Department to the Postmaster-General for the Year Ended June 30, 1914, pp. 8-12. 
has passed upon the legal acceptability of all bonds submitted as security for postal savings deposits. $^{25}$

The Board of 'Trustees in its first Regulations for the Guidance of Banks, issued December 31, 1910, made the following ruling ${ }^{26}$ in regard to the securities acceptable for postal savings deposits :

"The following described securities at rates respectively designated, will be accepted, [and no other] . . . (a) Interest bearing bonds of the United States, bonds issued by the Government of the Philippine Islands, and bonds of the District of Columbia and the Government of Porto Rico will be received at their par value.

Bonds of any State of the United States and bonds of the Territory of Hawaii will be received at 90 per cent of their market value, such market value not to be considered as exceeding par. (c) Bonds of any city, town, county, or other legally constituted municipality or district in the United States which has been in existence for a period of ten years, and which, for a period of ten years previous, has not defaulted in the pay-

${ }^{25}$ An account of his work in this connection and summaries of his decisions will be found in his annual reports.

${ }^{26}$ Regulations for the Guidance of Banks Qualifying as Depositories of Postal Savings Funds, etc., issued by authority of the Board of Trustees, 1911, pp. 4-5. 
ment of any part of either principal or interest of any funded debt authorized to be contracted by it, and whose net funded indebtedness does not exceed 10 per cent of the valuation of its taxable property, to be ascertained by the last preceding valuation for assessment of taxes, will be received at 75 per cent of their market value, such market value not to be considered as exceeding par. No deposit of bonds for less than one thousand dollars will be accepted, nor will fractions of a thousand be received." 27

In 1913 bonds in the group marked $(b)$ were made acceptable up to their market value provided it was not above par value; and bonds in group $(c)$, for cities having a census population of over 30,000, were made acceptable up to 90 per cent of their market value instead of only to 75 per cent as formerly. If the market value is above par they are acceptable only up to par. A fourth class of securities was designated at this time which are acceptable up to 75 per cent of

${ }^{27}$ This minimum of $\$ 1,000$ worked a hardship on banks in small places having fourth class post offices; and for banks in such places the minimum was later reduced to $\$ 500$. Since July 1, 1913, the minimum initial deposit of bonds required from banks has been $\$ 5,000$ in a place with a first class post office, $\$ 1,000$ in a place with a second or third class post office, and $\$ 500$ in a place with a fourth class post office. Regulations for the Guidance of Qualified Banks and Others, Effective July 1, 1913, p. 4. 
their market value (unless the market value is above par value). This last class consists of securities meeting the conditions mentioned for class $(c)$, except for the fact that they refer to places having a census population of not more than 30,000 .

Under date of March 30, 1917, the Board of Trustees added farm loan bonds authorized by act of Congress approved July 17, 1916, to the list of securities constituting group $(a)$ which are acceptable at their par value; and on April 24, the board added to the same list interest bearing certificates of indebtedness of the United States Government.

As collateral for postal savings deposits, municipal bonds have been by far the most popular type of security offered by banks; and the demand for high grade municipal bonds for postal savings collateral has been a substantial influence in the market for a number of issues. It is an interesting fact that not a dollar has yet been lost by the postal savings system through inadequacy of security given by depository banks.

\section{Rate of Interest Paid by Depository Banks}

Section 9 of the organic Postal Savings act says that the rate of interest paid by depository banks shall be "not less than 21 per centum per 
annum, which rate shall be uniform throughout the United States and Territories thereof." Although there was considerable sentiment for a higher rate, the Board of Trustees, at its meeting of December 31, 1910, fixed the rate at $2 \frac{1}{2}$ per cent per annum payable January $\mathbf{I}$ and July 1 each year "upon the average monthly balances." The term "average monthly balances" was at first interpreted to mean the average of the balances held on the last of each month. Inasmuch as the balances were normally growing throughout the month, the amount on the last day was unduly high, and this method of computing led justly to complaints on the part of depository banks. The basis was accordingly changed to the average daily balance, and this has been generally satisfactory.

Profits Realized by Banks on Postal Savings Accounts

Concerning the extent to which postal savings accounts have been profitable to depository banks it is unsafe to generalize. The profit varies with the prices of bonds acceptable as security; and the last few years have been years of unstable bond prices, and years of great uncertainty as to bond values in the future. It varies with the extent to which the deposits will cover the collateral 
deposited; and it varies with the actual amount of deposits obtainable-in many cases the accounts are too small to be worth the trouble. Many banks have not found it to their advantage to qualify as depositories, while others have realized good profits on such deposits, ${ }^{28}$ and in many communities the competition for them is keen. The advantage of advertising oneself as a depository of United States postal savings funds is valued highly by many banks.

\section{Postal Savings Bonds}

A discussion of the postal savings system would be incomplete without a reference to the postal savings $2 \frac{1}{2}$ per cent bonds authorized by the act of $1910 .^{29}$ The primary object of these bonds, which are issued in denominations as low as $\$ 20$, is to provide a safe and convenient form

${ }^{28}$ The writer has on his desk a circular issued by a prominent bond house, in which are computed the rates of interest that would be realizable on the net investment in the case of $\$ 100,000$ par value of six different high grade bonds, against which it is assumed the maximum postal savings deposits allowed by the Department's regulations would be received. The rates per annum on the net investments vary from 4.8 per cent to 19.36 per cent.

Banks often complain of the large "amount of red tape" that deposits of postal savings funds entail.

${ }^{29}$ The bonds are redeemable at the pleasure of the United States after one year from date of issue, and are payable twenty years from date of issue. 
of government security for the thrifty poor, and particularly for those whose deposits in the postal savings banks have reached the legal maximum. These bonds have been issued on the first day of each January and July since the postal savings system was put into operation, and the total issue up to the close of the fiscal year 1917 was $\$ 10,000,000$. Of this sum approximately 87 per cent was, on request, issued in the registered form, which indicates, in the judgment of the Third Assistant Postmaster-General, "that they were purchased for permanent investment." 30

On November 8, 1911, it was reported in the newspapers that some of these bonds had been sold at $92 \frac{1}{2}$. The report, which was apparently false, ${ }^{31}$ caused some anxiety, and the Board of Trustees, who were authorized by the Postal Savings act (section 10) to invest postal savings funds in these bonds, promptly passed a resolution to purchase them at par upon the application of any holder, and to make immediate payment therefor in cash. Up to February 1, 1917, the board had purchased $\$ 2,045,920$ worth of these bonds.

${ }^{30}$ Ann. Rep., 1916, p. 11.

31 The New York Times of November 18, 1911, quoted Postmaster-General Hitchcock as saying that "the only basis for the rumor of an actual sale at that price [921/2] was an offer .. . by a New York broker to purchase $\$ 200$ of the bonds below par, which was not accepted by the holder." 


\section{CHAPTER VI}

\section{Conclusion}

The postal savings system, despite the handicaps of a defective structure and of many hampering restrictions, has made substantial progress during the early years of its history, and has rendered the country a real service.

When the Postal Savings act was passed the only plan that had the slightest chance of getting through Congress was a highly decentralized one which would use existing banks as depositories, and try to keep the money deposited in postal banks "at home." This philosophy of keeping money at home meant little more than that the profits that were to be realized on the investment of postal savings funds should be given to local banks. Money is too fluid a form of capital to be "kept at home" if it is in materially greater demand in some other place. In 1910 it was less fluid in the United States than in most advanced countries. That was the time of a vigorous agitation for the reform of our currency and banking system, whose chief defects were generally recognized to be immobility and inelasticity of 
currency and credit. The meaning of this was, in part, that reserves and bank credit were kept too much at home when the public interest demanded a cheap and expeditious machinery for their prompt movement from places of redundancy to places of scarcity. But even under our defective banking system in 1910, money and bank credit were the most fluid forms of capital in the country, and were continually "leaving home." They are much more fluid in 1917 than they were in 1910, thanks to our Federal reserve system, our developing American discount market, and the rapid growth of the note brokerage business. The great bulk of the postal savings deposits is in large cities. For example, on June 30, 1916, New York City (including Brooklyn and Long Island City) had 24 per cent of the total postal savings deposits of the country. Does any one think that it is possible "to keep money at home" in our large cities by merely depositing it in commercial banks, or that it would be socially desirable to do so, if it were possible?

A Larger Use of Savings Banks as Depositories of Postal Savings Funds Desirable

This brings us to the last point. Six years of postal savings history in the United States has 
shown that postal savings funds come largely from hoards and from accumulations that would otherwise be sent abroad by our foreign born. As previously noted, 87 per cent of the postal savings bonds purchased are in the registered form and presumably for permanent investment. All this seems to indicate that postal savings funds are more nearly capital funds than current business funds. Yet our depository system puts the great bulk of them into commercial banks. Should the system not be changed so as to divert a larger part of these savings into savings banks where they will be feeders for society's more permanent capital equipment?

At the present time this question is particularly opportune, for the evidence is strong that the next few years will witness a substantial increase in interest rates. This increase will bear heavily upon our mutual savings banks whose assets in the form of long-time bonds and mortgages are likely to decline in value at just the time that the higher interest rates payable on securities will be attracting funds away from savings banks into fields that appear to be more remunerative; for example, small denomination bonds. A more liberal use of savings banks as depositories for postal savings funds would assist these worthy institutions to tide over a trouble- 
some period of readjustment. The type of depositor who uses the postal savings system is not the one who will be induced to withdraw deposits in order to invest the funds in securities yielding a higher rate of interest. To accomplish much in the direction suggested would require an amendment to the Postal Savings act. The fact that savings banks, with few exceptions, are not members of the Federal reserve system is not a strong argument against this proposal, because there is no sound public policy in encouraging them to join as active members. ${ }^{1}$ The Federal reserve system is primarily a system for commercial banks. Could not our best grade savings banks wisely be put on an equal footing, at least, with commercial banks which are members of the Federal reserve system, with regard to qualifying as depositories for postal savings funds?

1 The Federal Reserve Board has recommended to Congress an amendment to the Federal reserve act authorizing mutual savings banks not having a capital stock to become associate members of the Federal reserve system, under certain prescribed conditions. It is a very desirable amendment. Federal Reserve Bulletin, Feb. 1, 1917, p. 101. 



\section{APPENDIX A}

\section{UNITED STATES POSTAL SAVINGS ACT AND ITS AMENDMENTS}

AN ACT TO ESTABLISH POSTAL SAVINGS DEPOSITORIES FOR DEPOSITING SAVINGS AT INTEREST WITH THE SECURITY OF THE GOVERNMENT FOR REPAYMENT THEREOF, AND FOR OTHER PURPOSES. ${ }^{1}$

$B e$ it enacted by the Senate and House of Representatives of the United States of America in Congress assembled, That there be, and is hereby, created a board of trustees for the control, supervision, and administration of the postal savings depository offices designated and established under the provisions of this act, and of the funds received as deposits at such postal savings depository offices by virtue thereof. Said board shall consist of the Postmaster General, the Secretary of the Treasury, and the Attorney General, severally, acting ex officio, and shall have power to make all necessary and proper regulations for the receipt, transmittal, custody, deposit, investment, and repayment of the funds deposited at postal savings depository offices.

The board of trustees shall submit a report to Congress at the beginning of each regular session showing by States and Territories (for the preceding fiscal year) the number and names of post offices receiving deposits, the aggregate

1 Amended by acts of Aug. 24, 1912 (see pp. 143144), Sept. 23, 1914 (see pp. 146-147), and May 18, 1916 (see pp. 141-150).

Board of trus. tees.

Personnel.

Report to Congress. 
amount of deposits made therein, the aggregate amount of withdrawals therefrom, the number of depositors in each, the total amount standing to the credit of all depositors at the conclusion of the year, the amount of such deposits at interest, the amount of interest received thereon, the amount of interest paid thereon, the amount of deposits surrendered by depositors for bonds issued by authority of this act, and the number and amount of unclaimed deposits. Also the amount invested in Government securities by the trustees, the amount of extra expense of the Post Office Department and the postal service incident to the operation of the postal savings

B r a cketed words in ital. ics amended by the act of September 23, 1914. page 146.

B r a c keted section in ital. ics amended by the act of September 23, $1914 . \quad$ See page 146.

Postal savings depository offices.

Hours of busi. ness. depository system, [the amount of rork done for the savings depository system by the Post Office Department and postal service in the transportation of free mail,] and all other facts which it may deem pertinent and proper to present.

[SEc. 2. That the Postmaster General is hereby directed to prepare and issue special stamps of the necessary denominations for use, in lieu of penalty or franked envelopes, in the transmittal of free mail resulting from the administration of this act.]

SEc. 3. That said board of trustees is hereby authorized and empowered to designate such post offices as it may select to be postal savings depository offices, and each and every post office so designated by order of said board is hereby declared to be a postal savings depository office within the meaning of this act and to be authorized and required to receive deposits of funds from the public and to account for and dispose of the same, according to the provisions of this act and the regulations made in pursuance thereof. Each postal savings depository office shall be kept open for the transaction of business during such hours as the Postmaster General, with 
the approval of the board of trustees, shall direct.

SEc. 4. That accounts may be opened and deposits made in any postal savings depository established under this act by any person of the age of ten years or over, in his or her own name, and by a married woman in her own name and free from any control or interference by her husband; but no person shall at the same time have more than one postal savings account in his or her own right.

SEC. 5. That the postmaster at a postal sav- Pass books. ings depository office shall, upon the making of an application to open an account under this act and the submission of an initial deposit, deliver to the depositor a pass book free of cost, upon which shall be written the name and signature or mark of the depositor and such other memoranda as may be necessary for purposes of identification, in which pass book entries of all deposits and withdrawals shall be made in both figures and writing: Provided, That the Postmaster General may, with the approval of the board of trustees, adopt some other device or devices in lieu of a pass book as a means of making and preserving evidence of deposits and withdrawals.

SEc. 6. That at least one dollar, or a larger amount in multiples thereof, must be deposited before an account is opened with the person depositing the same, and one dollar, or multiples thereof, may be deposited after such account has been opened, [but no one shall be permitted to deposit more than one hundred dollars in any one calendar month] : Provided, That in order that smaller amounts may be accumulated for deposit any person may purchase for ten cents from any depository office a postal savings card to which may be attached specially prepared ad-

Opening of accounts.

Age of depositors.

Married women.

One pers on one account.

Device in lieu of pass books.

Deposits:

At least one dollar.

Multiples of one dollar.

B racketied wonds in italics amended by the act of May 18, 1916. See page 147.

Postal savings cards. 

Postal savings hesive stamps, to be known as "postal savings
stamps. stamps," and when the stamps so attached amount to one dollar, or a larger sum in multiples thereof, including the ten-cent postal savings card, the same may be presented as a deposit for opening an account, and additions may be made to any account by means of such card and stamps in amounts of one dollar, or multiples thereof, and when a card and stamps thereto attached are accepted as a deposit the postmaster shall immediately cancel the same. It is hereby made the duty of the Postmaster General

Sale of postal savings cards and stamps.

Interest on de. posits:

Entered once a year.

Subject to regulation.

B r a c k e t ed words in italics amended by the act of May 18, 1916. See page 147.

Withdrawal of deposits.

Paid from local depositories. to prepare such postal savings cards and postal savings stamps of denominations of ten cents, and to keep them on sale at every postal savings depository office, and to prescribe all necessary rules and regulations for the issue, sale, and cancellation thereof.

SEC. 7. That interest at the rate of two per centum per annum shall be allowed and entered to the credit of each depositor once in each year, the same to be computed on such basis and under such rules and regulations as the board of trusteees may prescribe; but interest shall not be computed or allowed on fractions of a dollar: [Provided, That the balance to the credit of any one person shall never be allowed to exceed five hundred dollars, exclusive of accumulated interest.]

SEc. 8. That any depositor may withdraw the whole or any part of the funds deposited to his or her credit, with the accrued interest, upon demand and under such regulations as the board of trustees may prescribe. Withdrawals shall be paid from the deposits in the State or Territory, so far as the postal funds on deposit in such State or Territory may be sufficient for the purpose, and, so far as practicable, from the deposits in the community in which the deposit was 
made. No bank in which postal savings funds shall be deposited shall receive any exchange or other fees or compensation on account of the cashing or collection of any checks or the performance of any other service in connection with the postal saving depository system.

[SEc. 9. That postal savings funds received under the provisions of this act shall be deposited in solvent banks, whether organized under National or State lares, being subject to National or State supervision and examination, and the sums deposited shall bear interest at the rate of not less than two and one-fourth per centum per annum, which rates shall be uniform throughout the United States and Territories thereof; but five per centum of such funds shall be rithdrawn by the board of trustees and kept with the Treasurer of the United States, who shall be treasurer of the board of trustees, in lareful money as a reserve. The board of trustees shall take from such banks such security in public bonds or other securities, supported by the taxing power, as the board may prescribe, approve, and deem sufficient and necessary to insure the safety and prompt payment of such deposits on demand. The funds received at the postal savings depository offices in each city, town, village, and other locality shall be deposited in banks located therein (substantially in proportion to the capital and surplus of each such bank) rilling to receive such deposits under the terms of this act and the regulations made by authority thereof, but the amount deposited in any one bank shall at no time exceed the amount of the paid-in capital and one-half the surplus of such bank. If no such bank exist in any city, town, village, or locality, or if none where such deposits are made roill receive such deposits on the terms prescribed, then such funds shall be

Banks not to receive ex$\mathrm{change}$ or other fees.

B racketed section in italics superseded by section 2 of the act of May 18, $1916 . \quad$ See pp. 147-150. 
deposited under the terms of this act in the bank most convenient to such locality. If no such bank in any State or Territory is willing to receive such deposits on the terms prescribed, then the same shall be deposited reith the treasurer of the board of trustees, and shall be counted in making up the reserve of five per centum. Such funds may be withdrawn from the treasurer of said board of trustees and all other postal savings funds, or any part of such funds, may be at any time withdrawn from banks and saving depository offices for the repayment of postal savings depositors when required for that purpose. Not exceeding thirty per centum of the amount of such funds may at any time be withdrawn by the trustees for investment in bonds or other securities of the United States, it being the intent of this act that the residue of such funds, amounting to sixty-five per centum thereof, shall remain on deposit in the banks in each State and Territory roilling to receive the same under the terms of this act, and shall be a roorking balance and also a fund which may be withdrawn for investment in bonds or other securities of the United States, but only by direction of the President, and only rohen, in his judgment, the general welfare and the interests of the United States so require. Interest and profit accruing from the deposits or investment of postal savings funds shall be applied to the payment of interest due to postal savings depositors as hereinbefore provided, and the excess thereof, if any, shall be covered into the Treasury of the United States as a part of the postal revenuel: Provided, That postal savings funds in the treasury of said board shall be subject to disposition as provided in this act, and not otherwise: And provided further, That the board of trustees may at any time dispose of bonds held as postal 


\section{APPENDIX A}

savings investments and use the proceeds to meet withdrawals of deposits by depositors. For the purposes of this act, the word "Territory," as used herein, shall be held to include the District of Columbia, the District of Alaska, and Porto Rico, and the roord "bank" shall be held to include savings banks and trust companies doing a banking business.]

SEc. 10. That any depositor in a postal sav- Postal savings ings depository may surrender his deposit, or any part thereof, in sums of twenty dollars, forty dollars, sixty dollars, eighty dollars, one hundred dollars, and multiples of one hundred dollars and five hundred dollars, and receive in lieu of such surrendered deposits, under such regulations as may be established by the board of trustees, the amount of the surrendered deposits in United States coupon or registered bonds of the denominations of twenty dollars, forty dollars, sixty dollars, eighty dollars, one hundred dollars, and five hundred dollars, which bonds shall bear interest at the rate of two and onehalf per centum per annum, payable semiannually, and be redeemable at the pleasure of the United States after one year from the date of their issue and payable twenty years from such date, and both principal and interest shall be payable in United States gold coin of the present standard of value: Provided, That the bonds herein authorized shall be issued only (first) when there are outstanding bonds of the Exchange of deposits.

Denomina. tions.

Interest.

Redeemable af ter one year. Payable after twenty years, in gold coin.

When bonds may be is. ued. proceeds of the bonds shall be applied to the redemption at par of outstanding bonds of the United States subject to call, and (second) at times when under authority of law other than that contained in this act the Government desires to issue bonds for the purpose of replenishing the Treasury, in which case the issue of bonds 
under authority of this act shall be in lieu of the issue of a like amount of bonds issuable under authority of law other than that contained

Secretary of Treasury to prescribe reg. ulations bond issue.

Boand of trus. tees may invest in postal savings bonds.

Exempt from taxation.

Not receivable as security for issue of circulating notes by national banks.

Investment in United States bonds.

Bonds called for redemp. tion.

Bonds reissued to board of trustees. in this act: Provided further, That the bonds authorized by this act shall be issued by the Secretary of the Treasury under such regulations as he may prescribe: And provided further, That the authority contained in section nine of this act for the investment of postal savings funds in United States bonds shall include the authority to invest in the bonds herein authorized whenever such bonds may be lawfully issued: And provided further, That the bonds herein authorized shall be exempt from all taxes or duties of the United States as well as from taxation in any form by or under State, municipal, or local authority: And provided further, That no bonds authorized by this act shall be receivable by the Treasurer of the United States as security for the issue of circulating notes by national banking associations.

SEc. 11. That whenever the trustees of the postal savings fund have in their possession funds available for investment in United States bonds they may notify the Secretary of the Treasury of the amount of such funds in their hands which they desire to invest in bonds of the United States subject to call, whereupon, if there are United States bonds subject to call, the Secretary of the Treasury shall call for redemption an amount of such bonds equal to the amount of the funds in the hands of the trustees which the trustees desire to thus invest, and the bonds so called shall be redeemed at par with accrued interest at the Treasury of the United States on and after three months from the date of such call, and interest on the said bonds shall thereupon cease: Provided, That the said bonds when redeemed shall be reissued at part to the 
trustees without change in their terms as to rate of interest and date of maturity: And provided further, That the bonds so reissued may, in the discretion of the Secretary of the Treasury, be called for redemption from the trustees in like manner as they were originally called for redemption from their former owners whenever there are funds in the Treasury of the United States available for such redemption.

SEc. 12. That postal savings depository funds shall be kept separate from other funds by postmasters and other officers and employees of the postal service, who shall be held to the same accountability under their bonds for such funds as for public moneys; and no person connected with the Post Office Department shall disclose to any person other than the depositor the amount of any deposits, unless directed so to do by the Postmaster General. All statutes relating to the safekeeping of and proper accounting for postal receipts are made applicable to postal postmasters, assistant postmasters, and clerks at postal savings depositories to give any additional bond he may deem necessary.

[SEc. 13. That additional compensation shall be allowed postmasters at post offices of the fourth class for the transaction of postal savings depository business. Such compensation shall noe exceed one-fourth of one per centum on the average sum upon which interest is paid each calendar year on receipts at such post office, and shall be paid from the postal revenues; but postmasters, assistant postmasters, clerks, or other employees at post offices of the presidential grade shall not receive any additional compensation for such service.]

SEc. 14. That the sum of one hundred thousand dollars is hereby appropriated, out of any money in the Treasury not otherwise appro-

Redemption of bonds so reissued.
Postal savings funds to be kept separate by postmasters.

Deposits held confidential.

Laws relating to safekeeping of postal funds made applicable.

Additional bond.

B r a cket ed section in italics amended by the act of September 23. 1914. See pp. 146-147.

Appropriation. 
priated, or so much thereof as may be necessary, to enable the Postmaster General and the board of trustees to establish postal savings depositories in accordance with the provisions of this act, including the reimbursement of the

Reimbursement of Secretary of the Treasury.

Postmaster General may require postal employees to transact postals a vings business.

Postmaster General may make $\mathrm{r} u \mathrm{les}$ and regula. tions subject to approval of board of trustees.

Protective and criminal statutes made ap. plicable to postal savings funds.
Secretary of the Treasury for expenses incident to the preparation, issue, and registration of the bonds authorized in this act; and the Postmaster General is authorized to require postmasters and other postal officers and employees to transact, in connnection with their other duties, such postal savings depository business as may be necessary; and he is also authorized to make, and with the approval of the board of trustees to promulgate, and from time to time to modify or revoke, subject to the approval of said board such rules and regulations not in conflict with law as he may deem necessary to carry the provisions of this act into effect.

SEc. 15. That all the safeguards provided by law for the protection of public moneys, and all statutes relating to the embezzlement, conversion, improper handling, retention, use, or disposal of postal and money-order funds and the punishments provided for such offenses are hereby extended and made applicable to postal savings depository funds, and all statutes relating to false returns of postal and money-order business, the forgery, counterfeiting, alteration, improper use or handling of postal and moneyorder blanks, forms, vouchers, accounts, and records, and the dies, plates, and engravings therefor, with the penalties provided in such statutes, are hereby extended and made applicable to postal savings depository business, and the forgery, counterfeiting, alteration, improper use or handling of postal savings depository blanks, forms, vouchers, accounts, and records, and the dies, plates, and engravings therefor. 
SEc. 16. That the faith of the United States is solemnly pledged to the payment of the deposits made in postal savings depository offices, with accrued interest thereon as herein provided.

Sec. 17. That the final judgment, order, or decree of any court of competent jurisdiction adjudicating any right or interest in the credit of any sums deposited by any person with a postal savings depository if the same shall not have been appealed from and the time for appeal has expired shall, upon submission to the Postmaster General of a copy of the same, duly authenticated in the manner provided by the laws of the United States for the authentication of the records and judicial proceedings of the courts of any State or Territory or of any possession subject to the jurisdiction of the United States, when the same are provide or admitted within any other court within the United States, be accepted and pursued by the board of trustees as conclusive of the title, right, interest, or possession so adjudicated, and any payment of said sum in accordance with such order, judgment, or decree shall operate as a full and complete discharge of the United States from the claim or demand of any person or persons to the same.

Approved, June 25, 1910.

AN ACT MAKING APPROPRIATIONS FOR THE SERVICE OF THE POST OFFICE DEPARTMENT FOR THE FISCAL YEAR ENDING JUNE THIRTIETH, NINETEEN HUNDRED AND THIRTEEN, AND FOR OTHER PURPOSES.

Be it enacted by the Senate and House of Representatives of the United States of America in Congress assembled.

SEc. 10. *** That all expenditures in the Audit. . Postal Savings System shall be audited by the

Pledge for repayment of deposits.

Adjudication

of courts will be conclusive as to rights in postal savings funds. 
Auditor for the Post Office Department: And

Postmaster General:

To designate offices.

To make appointments.

To prescribe hours of business.

To make regulations as to deposits and withdrawals.

Act of June 25,1910 , amended. provided further, That the Postmaster General shall select and designate the post offices which are to be postal savings depository offices, and shall appoint and fix the compensation of such superintendents, inspectors, and other employees as may be necessary in conducting, supervising, and directing the business of such offices, including the employees of a central office at Washington, District of Columbia, and shall prescribe the hours during which postal savings depository offices shall remain open. He shall also from time to time make rules and regulations with respert to the deposits in and withdrawals of moneys from postal savings depositories and the issue of pass books or such other devices as he may adopt as evidence of such deposits or withdrawals. The provisions of the act approved June twenty-fifth, nineteen hundred and ten, are hereby modified accordingly.

Approved, August 24, 1912.

AN ACT TO AMEND THE ACT APPROVED MAY NINTH, EIGHTEEN HUNDRED AND EIGHTY-EIGHT, AS AMENDED BY THE ACT OF JUNE ELEVENTH, EIGHTEEN HUNDRED AND NINETY-SIX.

Be it enacted by the Senate and House of Representatives of the United States of America in Congress assembled, That the act authorizing the Postmaster General to adjust certain claims of postmasters for loss by burglary, fire, or other unavoidable casualty, approved May ninth, eighteen hundred and eighty-eight, as amended by the act of June eleventh, eighteen

Postmaster General to in. vestigate and pay $\mathrm{cla} \mathrm{i} \mathrm{m} \mathrm{s}$ for losses by casualty. hundred and ninety-six, be, and the same is hereby, amended so as to read as follows:

"That the Postmaster General be, and he is hereby, authorized to investigate all claims of 
postmasters for the loss of money-order funds, postal funds, postal savings funds, postage stamps, stamped envelopes, newspaper wrappers, postal cards, postal saving cards, postal savings stamps, and postal savings certificates belonging to the United States in the hands of such postmasters, and for the loss of key-deposit funds, funds deposited to cover postage on mailings, and funds received as deposits to cover orders for stamped envelopes, in the hands of such postmasters, resulting from burglary, fire, or other unavoidable casualty, and if he shall determine that such loss resulted from no fault or negligence on the part of such postmasters, to pay to such postmasters or credit them with the amount so ascertained to have been lost or destroyed, and also to credit postmasters with the amount of any remittance of money-order funds, postal funds, or postal saving funds made by them in compliance with the instructions of the Postmaster General, which shall have been lost or stolen while in transit by mail from the office of the remitting postmaster to the office designated as his depository, or after arrival at such depository office and before the postmaster at such depository office has become responsible therefor: Provided, That no claim exceeding the sum of $\$ 10,000$ shall be paid or credited until after the facts shall have been ascertained by the Postmaster General and reported to Congress, together with his recommendation thereon, and an appropriation made therefor: And provided further, That this act shall not embrace any claim for losses as aforesaid which accrued more than four years prior to the date of approval of this act; and all such claims must be presented within six months after such date, and no claims for losses which may hereafter accrue shall be allowed unless presented within six months from the time the loss occurred."

Provisos.
Losses over $\$ 10,000$ to be reported to Congress.

Limitations. 
Annual report. Law governing other official mail made applicable to postal savings matter.

Cost of carry. ing pos tal savings mail no longer to be reported to Congress.

No extra compensation to postmasters or or postal em. ployees for transacting postal savings business.
Sec. 2. That it is hereby made the duty of the Postmaster General to report his action herein to Congress annually, with his reasons therefor in each particular case.

Approved, January 21, 1914.

AN ACT TO AMEND THE ACT APPROVED JUNE TWENTY-FIFTH, NINETEEN HUNDRED AND TEN, ENTITLED “AN ACT TO ESTABLISH POSTAL SAVINGS DEPOSITORIES FOR DEPOSITING SAVINGS AT INTEREST WITH THE SECURITY OF THE GOVERNMENT FOR REPAYMENT THEREOF, AND FOR OTHER PURPOSES."

Be it enacted by the Senate and House of Representatives of the United States of America in Congress assembled, That sections two and thirteen of the ... [postal savings act] be hereby amended to read as follows:

"SEc. 2. That provisions of section three of the act of July fifth, eighteen hundred and eighty-four, entitled 'An act making appropriations for the service of the Post Office Department for the fiscal year ending June thirtieth, eighteen hundred and eighty-five, and for other purposes,' are hereby extended and made applicable to all official mail matter pertaining to the business of the postal savings system; and hereafter the board of trustees for the control, supervision, and administration of the postal savings depository system shall not be required to show in the annual report prescribed by section one of the act of June twenty-fifth, nineteen hundred and ten, establishing such system, the amount of work done for that system by the Post Office Department and postal service in the transportation of free mail.

"SEc. 13. Postmasters, assistant postmasters, clerks, or other employees at post offices of the presidential grade, and postmasters at post offices of the fourth class, shall not be allowed or 
paid any additional compensation for the transaction of postal savings depository business."

Approved, September 23, 1914.

AN ACT TO AMEND THE ACT APPROVED JUNE TWENTY-FIFTH, NINETEEN HUNDRED AND TEN, AUTHORIZING THE POSTAL SAVINGS SYSTEM, AND FOR OTHER PURPOSES.

Be is enacted by the Senate and House of Representatives of the United States of America in Congress assembled, That such part of section six of the ... [postal savings act], as reads "but no one shall be permitted to deposit more than $\$ 100$ in any one calender month" is hereby amended to read as follows: "but the balance to the credit of any person, upon which interest is payable, shall not exceed $\$ 1,000$, exclusive of accumulated interest"; and said act is further amended so that the proviso in section seven thereof shall read as follows: "Provided, That the board of trustees may, in their discretion, and under such regulations as such board may promulgate, accept additional deposits not to exceed in the aggregate $\$ 1,000$ for each depositor, but upon which no interest shall be paid."

SEc. 2. That postal savings funds received under the provisions of this act shall be deposited in solvent banks, whether organized under $\mathrm{Na}$ tional or State laws, and whether member banks or not of the Federal reserve system established by the act approved December twenty-third, nineteen hundred and thirteen, being subject to National or State supervision and examination, and the sums deposited shall bear interest at the rate of not less than two and one-fourth per centum per annum, which rate shall be uniform throughout the United States and Territories thereof; but five per centum of such funds shall be withdrawn by the board of trustees and kept
Monthly limita. tion removed.

Maximum in. terest-bearing balance to the credit of a depositor.

Additional non. interest - bearing deposits.

Depository banks.

Minimum rate of interest.

Rate to be uniform.

Five per cent reserve. 
with the Treasurer of the United States, who

Treasurer of board of trustees.

Security fur$n$ ished by banks.

Postal savings funds.

Distribution in local banks.

Member banks of the Federal reserve system given preference.

Where no local bank exists.

Deposits with treasurer. shall be treasurer of the board of trustees, in lawful money as a reserve. The board of trustees shall take from such banks such security in public bonds or other securities, authorized by act of Congress or supported by the taxing power, as the board may prescribe, approve, and deem sufficient and necessary to insure the safety and prompt payment of such deposits on demand. The funds received at the postal savings depository offices in each city, town, village, and other locality shall be deposited in banks located tal and surplus of each such bank) willing to therein (substantially in proportion to the capireceive such deposits under the terms of this act and the regulations made by authority thereof: Provided, however, If one or more member banks of the Federal reserve system established by the act approved December twenty-third, nineteen hundred and thirteen, exists in the city, town, village, or locality where the postal savings deposits are made, such deposits shall be placed in such qualified member banks substantially in proportion to the capital and surplus of each such bank, but if such member banks fail to qualify to receive such deposits, then any other bank located therein may, as hereinbefore provided, qualify and receive the same. If no such member bank and no other qualified bank exists in any city, town, village, or locality, or if none where such deposits are made will receive such deposits on the terms prescribed, then such funds shall be deposited under the terms of this act in the bank most convenient to sucs locality. If no such bank in any State or Territory is willing to receive such deposits on the terms prescribed, then such funds shall be deposited with the treasurer of the board of trustees and shall be counted in making up the reserve of five per 
centum. Such funds may be withdrawn from the treasurer of said board of trustees, and all other postal savings funds, or any part of such funds, may be at any time withdrawn from the banks and savings depository offices for the repayment of postal sayings depositors when required for that purpose. If at any time the postal savings deposits in any State or Territory shall exceed the amount which the qualified banks therein are willing to receive under the terms of this act, and such excess amount is not required to make up the reserve fund of five per centum hereinbefore provided for, the board of trustees may invest all or any part of such excess amount in bonds or other securities of the United States. When, in the judgment of the President, the general welfare and interests of the United States so require, the board of trusthees may invest all or any part of the postal savings funds, except the reserve fund of five per centum herein provided for, in bonds or other securities of the United States. The board of trustees may in its discretion purchase from the holders thereof bonds which have been or may be issued under the provisions of section ten of the act of June twenty-fifth, nineteen hundred and $t=n$. Interest and profit accruing from the deposits or investment of postal savings funds shall be applied to the payment of interest due to postal savings depositors, as hereinbefore provided, and the excess thereof, if any, shall be covered into the Treasury of the United States as a part of the postal revenue: Provided further, That postal savings funds in the treasury of said board shall be subject to disposition as provided in this act, and not otherwise: $A$ nd provided further, That the board of trustees may at any time dispose of bonds held as postal savings investments and use the proceeds to

All f u n d s available for repayment of depositors.

Excess deposits in any State may be invest. ed in United States bonds.

All funds except reserve may be in. vested by direction of the President.

Board of trustees may purchase postal savings bonds from holders.

Interest and profit applied to payment of interest.

Excess to be covered into postal revenue.

Unauthorized disposition of funds forbid. den.

Dispos a 1 of investment bonds to meet withdrawals. 
Meaning "Territory." meet withdrawals of deposits by depositors. For the purposes of this act the word "Territory" as used herein shall be held to include the District of Columbia, the District of Alaska, and

Savings banks Porto Rico, and the word "bank" shall be held and trust to include savings banks and trust companies companies. doing a banking business.

Repeal of con- SEc. 17. That all laws or parts of laws in
flicting laws. conflict with the provisions of this act are hereby repealed.

Approved, May 18, 1916. 


\section{APPENDIX B, No. 1}

\section{THE PHILIPPINE POSTAL SAVINGS SAVINGS BANK ACT, AS AMENDED \\ TO JULY $1,1917^{1}$}

AN ACT TO ENCOURAGE ECONOMY AND SAVING AMONG THE PEOPLE OF THE PHILIPPINE ISLANDS, AND TO THAT END TO PROVIDE FOR THE ESTABLISHMENT OF POSTAL SAVINGS BANKS AND THEIR ADMINISTRATION THROUGH THE ORGANIZATION OF A POSTAL SAVINGS BANK DIVISION IN THE BUREAU OF POSTS, AND FOR OTHER PURPOSES.

By authority of the United States, be it enacted by the Philippine Commission, that:

Section 1. There shall be established in the Philippine Islands, under the control and management of the Director of Posts, an institution to be known as the Philippine Postal Savings Bank.

SEc. 2. (a) In order to facilitate the proper administration of the Philippine Postal Savings Bank, there is hereby created, as a part of the The Postal Savings Bank Division and its duties. Bureau of Posts, a division to be known as the postal savings bank division, which shall be presided over by an officer to be known as the chief

1 Amendments were made on the following dates: March 22, 1907; May 19, 1909; April 19, 1910; and January 26, 1915; Act No. 1640, of May 3, 1907, which is given on pages 168-169, is also amendatory of the Philippine Postal Savings Bank act, although the Legislature did not incorporate it in the act as an amendment. 
of the postal savings bank division, who shall receive a salary of six thousand pesos a year and perform his duties subject to the direction of the Director of Posts.

(b) The chief of the postal savings bank division shall be required to keep a separate set of books dealing solely with the operations of the Postal Savings Bank, and to make a monthly statement of the same to the Director of Posts and to the Secretary of Commerce and Police, and at the end of eac hfiscal year an annual report covering in detail the operations of the postal savings bank division.

(c) The chief of the postal savings bank division shall, before entering upon the duties of his office, execute a bond to the Insular Government in a sum to be fixed by the Insular Auditor, with sufficient surety or sureties, to be approved by and filed with the Insular Auditor. The Insular Auditor may, from time to time, require that the bond shall be increased or decreased according as the exigencies of the service require.

Depositors. SEC. 3. (a) Any person six years of age or over residing in the Philippine Islands, and not under legal disability, may open an account to his own credit in the Philippine Postal Savings Bank.

(b) Any person resident in the Philippine Islands, twenty-three years of age or over, and any person under twenty-three years of age who is the head of a family, may open an account for, or make deposits to the credit of the account of, any minor, or any person who, by reason of physical or mental disability, is unable to manage his own affairs.

(c) Any charitable or benevolent society in the Philippine Islands may, with the approval, previously obtained in writing, of the Director 
of Posts, open and maintain an account in the Postal Savings Bank.

SEC. 4. No person or society shall have more than one account to his or its own credit in his or its own name upon penalty of forfeiting under due process of law twenty-five per centum of all deposits so held contrary to law: Provided, That the above provision shall not prevent a person from acting as trustee in any number of accounts and at the same time maintaining an account of his own.

SEc. 5. Upon opening an account with the Postal Savings Bank, a person must state his name in full, his age, residence, occupation, and, in case the account is being opened in behalf of some other individual, or some society, the name, residence, or location of said individual or society, together with his relation thereto. A person upon opening an account with the Postal Savings Bank must declare that he has read or had read to him the rules and regulations of the Postal Savings Bank, and that he is willing to act in accordance therewith. Before receiving a deposit book he must sign a statement to the effect that he receives no benefit from any other account in the Postal Savings Bank, unless it be as a trustee, the representative of a deceased depositor, or as a member of some charitable or provident society. If the statements above referred to should be found to be false, twenty-five per centum of all sums deposited to the credit of the person making said false statements shall be liable to forfeiture by due process of law. SEc. 6. (a) Immediately upon the passage
of this Act postal savings banks shall be established in Manila, Iloilo, and Cebu; and the Director of Posts shall, subject in each case to the approval of the Secretary of Commerce and
Opening a postal savings account.
Creation of
postal savings
ban ks and
their classifi-
cation. 
Police, establish postal savings banks in other cities, towns, and villages of the Philippine Islands as rapidly as practicable.

(b) For the performance of the duties prescribed in this Act, the Director of Posts shall divide the postal savings banks of the Philippine Islands into three classes, to be known as postal savings banks of the first, second, and third class, respectively.

(c) Postal savings banks of the first class shall receive deposits to any amount and permit withdrawals of any amount, subject to the provisions of this Act.

(d) Postal savings banks of the second class shall not receive any single deposit of over one hundred pesos, nor shall they receive deposits to the credit of any one account of more than two hundred pesos for any one month. Withdrawals of deposits shall not be permitted through postal savings banks of the second class of more than two hundred pesos a month, and no depositor shall be permitted to withdraw deposits from postal savings banks of the second class oftener than twice each calendar month.

(e) Postal savings banks of the third class shall receive deposits only by means of postal savings bank stamps, as provided in section nine of this Act. No single deposit in the form of stamps shall be received by a postal savings bank of the third class to an amount exceeding twenty-five pesos, nor shall deposits amounting to more than fifty pesos be received by a postal savings bank of the third class to the credit of one account during any one month, and no depositor shall be permitted to withdraw deposits from postal savings banks of the third class oftener than twice each calendar month. No depositor shall be permitted to withdraw through a postal savings bank of the third class over fifty 
pesos at one time or over one hundred pesos during any one month.

(f) The maximum limits of deposits, credits, and withdrawals provided for in this section shall be doubled in the case of deposits, credits, and withdrawals, respectively, of the charitable and benevolent societies referred to in paragraph (c) of section three of this Act.

(g) No deposit shall be received and no deposit entry made for a sum less than one peso, except in the case of accrued interest.

SEC. 7. Any person or society having a deposit account with the Postal Savings Bank shall, subject to the provisions of this Act, be permitted to make deposits to the credit of said account or withdrawals from said account at any postal savings bank in the Philippine Islands.

Sec. 8. Each depositor in the Postal Savings Deposit books. Bank shall be entitled to receive, free of charge, a deposit book, to be obtained in the manner hereinafter stated.

(a) If the deposit be made at Manila he shall receive his deposit book, with the proper entries therein, upon making the initial deposit. Subsequent deposits at Manila shall be received by the head office upon presentation either in person or by agent of the sum to be deposited and the deposit book, and thereupon proper entry shall be made upon the deposit book and the deposit book shall be immediately returned to the depositor.

(b) If the initial deposit be made at any other post-office than that at Manila, the depositor must sign an application for a deposit book, stating his name, occupation or profession, and place of residence, and sign the declaration required by section five hereof. The deposit book must be obtained from the central office. A preliminary receipt for the amount of the first deposit 
will be given to the depositor, who will be informed of the date upon which he should call to receive the deposit book. When the deposit book is handed over to the depositor, he will be required to return the preliminary receipt and sign a receipt for the deposit book, in addition to leaving a specimen of his signature on record in the post-office, if he be able to write, and if he be not able to write he shall leave in the postoffice a specimen of his thumb mark. The amount of the original deposit will be entered in the deposit book by the central office and the depositor will thus have a guaranty that the same has been received in that office. He should carefully see that the entry in the deposit book corresponds with the amount entered in the preliminary receipt before giving up the latter.

(c) To make subsequent deposits at any other post-office than at Manila, the depositor shall take or send the amount to be deposited with his deposit book to the post-office, and the amount of the deposit shall be entered in the deposit book and the balance due the depositor struck. The entry shall then be initialed by the postmaster and stamped with the date stamp of the office, the deposit book to be returned to the depositor or his agent who brings the deposit. It shall be the duty of the postmaster, by the first mail for Manila, to notify the central office of the amount and date of the deposit, the name and residence of the depositor, the number of his deposit book, and the balance to the depositor's credit, and the head office, upon receiving the information aforesaid, shall make the proper entries upon its books, and send to the depositor at his post-office address by first mail a receipt showing the amount and date of the deposit, the name and residence of the depositor, the number of the deposit book, and the balance to the de- 
positor's credit. If the receipt should not reach the depositor in proper time, or if when it reaches him it should show any signs of erasure and should not agree with the entry in the deposit book, the depositor should immediately apply to the head office, and renew his application again and again until he receives a satisfactory reply.

SEc. 9. (a) For the purpose of facilitating Postal savings deposits of small savings and of extending the privileges of the postal savings banks to the smaller communities, there shall be issued, by the Bureau of Posts, postal savings bank stamps in denominations of five, ten, and twenty centavos, respectively, which stamps shall be for sale at every postal savings bank in the Philippine Islands, and all moneys received in payment for said stamps shall be considered as postal savings bank deposits, a record of which shall be kept separate from the other accounts of the post-office.

(b) Every postal savings bank shall furnish without charge to any person purchasing postal savings bank stamps the appropriate cards arranged with five, ten or twenty blank spaces, each bearing a distinctive number, for the pasting on of the above-mentioned stamps. The cards shall be of three different colors, arranged for the three different denominations of stamps, respectively, and only stamps of the denominations designated shall be placed on the respective kind of cards. The postmaster upon giving out a card shall stamp it with the stamp of his office and shall require the person receiving it to sign it with his name, or mark, and transfers of cards shall be made only by indorsement to order.

(c) Stamp cards, upon being properly filled with stamps, may be presented at any postal 
savings bank in the Philippine Islands and deposited as if they were money of the amount represented by the face value of the stamps, and the procedure for making such deposits shall be the same as that provided for deposits of money, in section eight of this Act. The chief of the postal savings bank division shall cancel all stamps received for deposit at the time the deposit entry is made to the depositor's credit.

(d) Employees of the Postal Savings Bank, and all persons intrusted with the handling or custody of postal savings bank stamps, whether said stamps shall have been canceled or not, shall be held responsible for them in the same manner and to the same extent as if they were Insular money of a value equal to the face value of the stamps.

(e) Uncanceled postal savings bank stamps shall be redeemable at par in postage stamps at the office of the chief of the postal savings bank division.

SEc. 10. Interest at two and one-half per centum per annum shall be allowed on all deposits in the Postal Savings Bank until practical experience shall demonstrate that a higher rate can safely be guaranteed, subject to the following limitations:

(a) In the reckoning of interest, the day upon which the deposit was entered to the credit of the depositor upon the books of the chief of the postal savings bank division shall be considered as the date of the deposit.

(b) Money to the credit of any depositor in excess of one thousand pesos shall not bear interest, except in the case of deposits made by charitable and benevolent societies as provided in paragraph $(c)$ in section three, in which case deposits in excess of two thousand pesos shall not bear interest. 
(c) Interest shall be computed upon the lowest monthly balance to the credit of the account during each month of the fiscal year and shall be placed to the depositor's credit at the end of each fiscal year: Provided, That if the account is closed during the fiscal year the interest shall be added at the time the account is closed.

(d) No interest shall be allowed upon fractions of a peso or for the fractional part of a calendar month.

(e) The Philippine Government reserves the right to alter the rate of interest at the end of each fiscal year.

(f) At the end of each fiscal year the chief of the postal savings bank division shall send a statement of the interest accrued on each deposit to every depositor, and a duplicate statement of the same to the postmaster of the postal savings bank most convenient to the residence of said depositors, respectively, and said postmasters shall, upon presentation of the deposit books by the respective depositors, together with the above-mentioned statement, enter the amount as a deposit in the deposit book of said depositor in the manner provided in section eight of this Act.

(g) Any postal savings bank account upon which there has not been made, for a period of ten years, any deposit, withdrawal, or other operation made on demand of the depositor, or his legal representatives or assignees, shall cease to be productive of interest and shall be reimbursable at the amount existing to the credit of said depositor upon the thirtieth of June following the date upon which said ten-year period shall have expired: Provided, That in the case of deposits made by one person or society to the credit of another person or society under the stipulation that the latter person or society shall 
not have the disposal of said funds until after a fixed period of time, the said period of ten years shall date from the expiration of the period so fixed.

Transfer of de posited f und s to Treasurer

Sec. 11. Postal savings bank funds depositIslands. ed in the various postal savings banks in the Philippine Islands shall be transferred through the Director of Posts to the Treasurer of the Philippine Islands for the credit of the Philippine Postal Savings Bank, at such time and by such methods as the Director of Posts shall direct: Provided, That no postmaster of any postal savings bank of the first class shall at any time hold in his possession, for a longer period than is absolutely necessary to provide for its shipment to Manila, more than five thousand pesos, except upon the express authorization of the Director of Posts ; no postmaster of any postal savings bank of the second class shall at any time hold in his possession, under like conditions, more than one thousand pesos of postal savings bank funds, and no postmaster at any postal savings bank of the third class over two hundred pesos.

SEc. 12. All postal savings bank funds and all proceeds therefrom shall be kept as a separate trust fund by the Insular Treasurer, and shall be used for no other purpose than those expressly provided for in sections eighteen, nineteen, and twenty of this Act.

Withdrawal of funds by deposits.
SEC. 13. (a) A depositor wishing to make a withdrawal shall present his deposit book at the office where the withdrawal is to be made, and shall sign in the presence of some officer of said postal savings bank, who shall witness the same by his own signature, an application for the amount to be withdrawn. This application shall be forwarded to the chief of the postal savings bank division, who, upon being satisfied that the 
application is a bona fide one, and that funds sufficient for its payment are to the credit of the depositor, shall debit the amount to be withdrawn upon the depositor's account at his office, and forward to the said postmaster a warrant for the payment to the depositor of the amount applied for. The depositor, upon receiving payment from the postmaster of the sum withdrawn, shall sign a receipt in triplicate, one copy of which shall be forwarded to the Insular Auditor, one to the chief of the postal savings bank division, and one retained by the postmaster making the payment. The postmaster upon making the payment shall debit the amount paid upon the depositor's deposit book and strike therein a new balance, placing opposite the entry his initials and the stamp of his office.

(b) In case there are not sufficient funds available at the postoffice where the withdrawal is desired, the postmaster of said office shall, at the time he sends the application for withdrawal to the chief of the postal savings bank division, make a requisition upon the chief of the postal savings bank division for the sum necessary to meet the withdrawal applied for, and said sum shall be sent by the chief of the postal savings bank division to the postmaster at whose office the application for said withdrawal was made.

(c) Withdrawals may be made by telegraph under the following regulations:

Application for withdrawal must be made to the proper postmaster as provided in this section and the cost of the telegram to the chief of the postal savings bank division paid by the applicant at the time the application is made. The telegram shall then be sent by the postmaster to the chief of the postal savings bank division. Upon being satisfied that the application is a bona fide one and that there are funds to the 
credit of the depositor sufficient to meet the same, a warrant for the amount, less the cost of the return telegram, shall be telegraphed to the postmaster, who, upon receipt of the same, shall make the payment as provided in paragraph $(a)$ of this section. If there are not sufficient funds available at said post-office for the payment, said fact shall be mentioned by the postmaster in the aforementioned telegram, and the funds for the payment shall be sent as provided in paragraph $(b)$ of this section.

SEc. 14. (a) A depositor shall not be permitted to make more than two withdrawals from his deposit each calendar month.

(b) The Government reserves the right to delay the repayment of deposits for a period of two weeks in the case of withdrawals of amounts less than two hundred pesos, and one month in the case of withdrawals of amounts of two hundred pesos or over, in addition to the time necessary to forward the application for withdrawal from the post-office at which said application is made to the office of the chief of the postal savings bank division at Manila and to return the warrant issued in response to said application.

(c) A depositor shall not be permitted to withdraw a smaller sum than one peso, nor shall he be permitted to withdraw any sum which includes a portion of a peso: Provided, That in closing his account he may withdraw the entire amount to his credit.

(d) A minor shall not be permitted to withdraw money other than that deposited by himself in his own name, but, upon attaining his majority, he may withdraw any money deposited for him, in accordance with the conditions upon which such deposits were made.

Money deposited on behalf of a minor by his parent or guardian may be withdrawn only by 
said parent or guardian during the minority of the minor.

(e) Women, whether married or single, shall be permitted to withdraw money deposited by them in their own names, or, upon attaining their majority, money deposited for them by others, in accordance with the conditions upon which said deposits were made, and the fact of their marriage shall not alter this privilege.

SEC. 15. A depositor wishing to close his account shall present his deposit book with a form of application properly made out at the postal savings bank at which the withdrawal of the deposit is to be made. He shall receive from the postmaster a receipt for his deposit book, which receipt shall state the name and residence of the depositor, number of his deposit book, and the balance due him as shown by said book. The deposit book, together with the application for the withdrawal of the balance of the deposit and the closing of the account, shall be forwarded to the chief of the postal savings bank division in the same manner as requests for the withdrawal of deposits are forwarded, as provided in section thirteen, and payment of the balance due to his credit, including interest up to the close of the month preceding the receipt of his application, shall be made. Upon payment to the depositor he shall surrender to the postmaster the receipt given to him as in this section above provided. The deposit book shall be retained at the office of the chief of the postal savings bank division.

SEc. 16. (a) Depositors wishing to withdraw funds from their postal savings bank account and who are unable to make application in person at a postal savings bank for such withdrawals may, by filling out a proper application form and intrusting the same, together with their 
deposit book, to another person, authorize said person to make the application for withdrawal, and receive the receipt given by the postmaster for the deposit book and the funds to be withdrawn.

Nominations $f$ or transfer of deposit at death of depositor. (b) Any depositor of the age of majority may execute a nomination in connection with his postal savings bank account, providing for the transfer of his deposit or any part thereof at his death. Said nomination must be made in writing upon a proper form prepared for that purpose by the chief of the postal savings bank division. It must be signed by the depositor in the presence of a witness (other than the beneficiary of the nomination) and must be sent for registration to the chief of the postal savings bank division during the depositor's lifetime. The nomination shall then be returned to the depositor.

(c) Whenever a claim is made under a nomination executed by a depositor in the manner above provided, and in force at the depositor's death, the nominee shall be required, before receiving any benefits from the depositor's account, to forward, to the chief of the postal savings bank division, the nomination and the depositor's deposit book, together with satisfactory evidence of the depositor's death and of his identity as the person named in the nomination. The chief of the postal savings bank division, upon being satisfied from the abovementioned evidence of the death of the depositor, the identity of the nominee, and the legality of his claim, shall pay to the nominee the sum legally due him as provided in the nomination.

(d) In case no nomination is made during the depositor's life-time as herein provided, funds to his credit in the Postal Savings Bank at the time of his death shall be disposed of in the 
same manner as other property in accordance with the provisions of existing law.

SEc. 17. (a) No postal savings bank deposit shall be subject to taxation by the Insular Government, or any provincial or municipal government in the Philippine Islands.

(b) The deposit book of a depositor in the Postal Savings Bank shall not be a proper security for a loan, debt, or obligation of any kind, and no such claim of any person, firm, or corporation holding a deposit book of the Postal Savings Bank shall be recognized as a valid claim against a depositor's account.

(c) Deposits in the Postal Savings Bank which bear interest in accordance with the provisions of section ten of this Act shall not be

Deposits not attachable for debt.

liable to attachment for debt: Provided, That amounts to the credit of any depositor in excess of the limit upon which interest is payable shall be attachable the same as deposits in other banking institutions.

SEC. 18. (a) The investment of the funds of the Postal Savings Bank shall be in charge of a board to be known as the postal savings bank investment board, which shall be composed of the Secretary of Commerce and Police, the Secretary of Finance and Justice, the Director of Posts, the Insular Treasurer, and a business man to be appointed by the Governor-General, who shall serve without compensation. It shall be the duty of the postal savings bank investment board to invest the funds of the Postal Savings Bank as hereinafter provided, taking sufficient and proper security for investments made, and to perform such other duties as the proper investment and administration of the funds of the Postal Savings Bank shall require.

(b) The funds received upon deposit by the Postal Savings Bank shall be invested in any or

Investments eligible for postal savings bank funds.
The postal sav$r$ estmient board. 
Administration expenses.

Postal savings bank reserve fund. all of the following ways, and in no others, in such amounts and under such regulations as the postal savings bank investment board shall determine, unless otherwise provided by this Act:

1. Investment in bonds or other evidences of indebtedness of the United States.

2. Investment in bonds or other evidences of indebtedness of the Insular Government of the Philippine Islands, of the city of Manila, and of any municipality in the Islands having a paidup capital of one million five hundred thousand pesos or over: Provided, however, That not exceeding ten per centum of the total deposits shall be invested in such stocks or shares.

SEc. 19. All expenses properly chargeable to the administration of the Postal Savings Bank shall be paid from the profits arising from the investment of the postal savings bank funds: Provided, That if the profits arising from said investments are not sufficient during any year, together with the reserve fund accrued as hereinafter provided, to pay the interest upon the deposits and the expenses of administration, there shall be appropriated out of the general funds of the Insular Treasury, not otherwise appropriated at the time, sufficient funds to cover the deficit so created.

SEc. 20. Should the earnings of any fiscal year exceed the amount necessary for the payment of interest and the expenses of administration, the surplus shall be set aside as a special fund to be known as the postal savings bank reserve fund and as such shall be invested and permitted to accumulate until it shall equal five per centum of the interest-bearing deposits of the Postal Savings Bank. This fund shall be a trust fund and shall be used for no other purpose than to meet deficits in those years in which the earnings of the Postal Savings Bank shall 
not be sufficient to pay interest and to meet current expenses. Any net earnings of the Postal Savings Bank in addition to the amount necessary to establish and maintain the aforementioned reserve fund shall be utilized by the postal savings bank investment board for the purpose of increasing the rate of interest payable on deposits in the Postal Savings Bank.

SEc. 21. The public good requiring the speedy enactment of this bill, the passage of the same is hereby expedited in accordance with section two of "An Act prescribing the order of procedure by the Commission in the enactment of laws," passed September twenty-sixth, nineteen hundred.

Sec. 22. This Act shall take effect on its passage.

Enacted, May 24, 1906. 


\section{APPENDIX B, No. 2}

AN ACT AUthorizing THE POSTAL SAVINGS BANK INVESTMENT BOARD TO MAKE LOANS FROM FUNDS AVAILABLE FOR INVESTMENT TO PROVINCES OF THE PHILIPPINE ISLANDS, UNDER GUARANTEE OF THE INSULAR GOVERNMENT.

By authority of the United States, be it enacted by the Philippine Commission, that:

Section 1. The Postal Savings Bank Investment Board created by section eighteen of Act Numbered Fourteen hundred and ninety-three, entitled "An Act to encourage economy and saving among the people of the Philippine Islands, and to that end to provide for the establishment of postal savings banks and their administration through the organization of a Postal Savings Bank Division in the Bureau of Posts, and for other purposes," is hereby authorized to make loans from the funds under its control available for investment to provinces of the Philippine Islands, under guarantee of the Insular Government first had that the loan and interest thereon will be paid.

SEc. 2. Before making any such loan the Postal Savings Bank Investment Board shall require a resolution of the provincial board of the province to which the loan is to be made, requesting the loan, stating that the same will be used solely for certain public improvements specified therin, agreeing to repay the amount loaned within a certain period with interest at a rate to be stated in said resolution, and requesting 168 


\section{APPENDIX B}

the Insular Government to guarantee the repayment in full of said loan and interest. Said resolution shall further provide that the Insular Government may, from time to time, in consideration of its guaranty, deduct from any funds in the Insular Treasury belonging to the province sufficient sums to pay the interest and principal as the same may become due.

SEc. 3. The public good requiring the speedy enactment of this bill, the passage of the same is hereby expedited in accordance with section two of "An Act prescribing the order of procedure by the Commission in the enactment of laws," passed September twenty-sixth, nineteen hundred.

Sec. 4. This Act shall take effect on its passage.

Enacted, May 3, 1907. 



\section{INDEX}

Accounts, of depository banks, 126-127; of postal savings depositors, 30-31, 56-57; out of town, 119-120.

Administrative organization of rostal savings system, machinery of, reorganized in 1913, 51-52; provisions for, amended in 1911, 50; provisions for, in Act of 1910, 21-24.

Ages of depositors in postal savings offices, 63-65; table showing, 64 .

Amendment to Philippine Postal Savings Bank Act, text of, 168-169.

Amendments to U. S. Postal Savings Act, text of, 143-150.

American Bankers Association, changes attitude toward postal savings, 77, 96; opposition of, to postal savings, 13-15; report of, on savings facilities in U. S., 8-10.

Attachment for debt, exemption of postal savings from, 92; exemption of postal savings from, as means of evading obligations, 92-95.

Attorney-General, as member of Board of Trustees, 22-24; decision of, exempting postal savings from attachment for debt, 92.

Bailey, Senator J. W., views of, on constitutionality of postal savings bill, 38-41.

Banks, as holders of postal savings funds, 130-131; attitude of, toward postal savings system, 13-15, 76-77, 96; effects on, of competition of postal savings system, 12-16, 76-79; failures of, 17-19.

Board of Trustees, action of, relating to non-interest bearing postal savings deposits, 97-98; creation of, in 1910, 21-22; powers of, changed in 1911, 50; powers of, under Act of 1910, 22-24; purchases by, of postal savings bonds, 107-109, 127; regulations of, relating to depository banks, 109-111; regulations of, relating to payment of interest on postal savings deposits, 99-101; regulations of, relating to security for deposits of postal savings funds, 122-124; selects interest rate payable by depository banks, 125; Third Assistant Postmaster-General made secretary of, in 1913, 51.

Bonds as security for deposit of postal savings funds, 107, 120; kinds of, 120-124.

Borah amendment to postal savings bill, 49 .

Bradley, Senator W. O., mentioned, 37.

Bryan, Senator N. P., cited, 94-95. 
Carter, Senator T. H., author of Carter bill, 6 .

Carter bill, 6.

Certificates of deposit, adoption of, by Board of Trustees, 5657; compared with pass books as means of showing deposit credits, 30-31.

Children, as depositors of postal savings, 62-65, 92-93.

Cities, postal savings deposits in, 72-74, 129.

Compensation of postmasters in postal savings offices, 53-54.

Competition of postal savings system with banks, 12-16, 76-79.

Compound interest on postal savings deposits, non-payment of, 99-100.

Concentration of postal savings deposits in cities, 129.

Constitutionality of postal savings bill, debated in Senate, 37-42; Senator Bailey's views on, 38-41; Senator Root's views on, 41-42.

Cortelyou, G. B., Postmaster-General, cited, 3.

Decentralized system of depository banks, 128-131.

Deficit in operation of postal savings system, disappearance of, in 1914, 90-91.

Depositors in postal savings offices, age grouping of, 63-65; geographic distribution of, 66 et seq.; map showing geographic distribution of, 67; nativity of, 57-62; privileged to invest savings in $U$. S. bonds, 45-48; table showing age grouping of, 64; table showing nativity of, 59; tables showing geographic distribution of, 68,69 .

Depository banks, amount of interest paid by, compared with amount paid to postal savings depositors, 102-103; bill to change character of, vetoed in 1914, 114-115; character of, changed in 1916, 115-116; decentralized system of, 128-131; decline in number of, 111-112; interest rate paid by, 102-103, 124-125; out of town, 119-120; private banks as, 110-111; qualifications of, 110-111; selection of, under Act of 1910, 106-107; should include savings banks, 130-131; state banks as, 110 et seq.

Depository post offices, large number of inactive, 54-55; selection of, 23-24, 53-55.

Deposits in postal savings offices, arguments against limitations on size of, 88-91; arguments favoring limitations on size of, 9195; concentration of, in cities, 129 ; exemption of, from attachment for debt, 92-93; exemption of, from taxation, 93-95; geographic distribution of, 66 et seq.; growth of, 98-99; interest paid on, 31-35; limitations on size of, 24-25, 85 et seq.; map showing geographic distribution of, 71 ; method of crediting, 30-31, 56-57; not affected in legal rights by war, 84-85; per capita amounts of, in cities, 73-74; per capita amounts of, in U. S., 74-75; provisions for, in Act of 1910, 24-30; sources of, 75-79; tables showing geographic distribution of, 68-69, 73, 74; withdrawals of, 25-30, 101-104.

Deposits of postal savings funds in banks, interest paid on, 102103, 124-125; provisions for, in Act of 1910, 106 et seq.; regula- 
tions of Board of Trustees relating to, 110 et seq.; table showing percentage amounts of, 108.

District bonds, as security for deposits of postal savings funds, 122-124.

Division of Postal Savings, creation of, in 1913, 51-52.

Dockery, A. M., Third Assistant Postmaster-General, cited, 75, $79,90,97-98,100$.

Emergency credits of postmasters, abolition of, in 1913, 116-119; provision for, in 1910, 26-27.

Employees of postal savings system, payment of, 52.

Expenses of postal savings system, 90-91.

Farm loan bonds, as security for deposits of postal savings funds, 124.

Federal Reserve Act, prohibits non-member banks acting as depository banks, 112-113; restrictions of, modified in 1916, 115116; veto of amendment to, in 1914, 87, 114-115.

Federal Reserve system, banks of, as depositories of postal savings funds, 112 et seq.

Gallinger, Senator J. H., cited, 91.

Guaranty of bank deposits by State laws, 4.

Hawaiian bonds, as security for deposits of postal savings funds, 122-124.

Hawaiian postal savings system, 2.

Hitchcock, Senator G. M., cited, 93-94.

Hoarded money, brought out by postal savings system, 19-20, 75-79, 88.

Individual deposits in cities, 73-74.

Interest paid by depository banks, determination of rate of, 124125; provisions for, in Act of 1910,36, 44, 107; rate and amount of, 102.

Interest paid on postal savings deposits, advisability of changing regulations relating to, 104-105; amount of, compared with interest received by Government from depository banks, 102103; method of determining rate of, 31-32; regulations of Board of Trustees relating to, 99-101; selection of rate of, 31-35.

Investment of postal savings funds, in depository banks, 106 et seq. ; in $U$. $S$. bonds, 41-44, 48-49, 106-109; problem of, 35-36; provisions for, changed in 1916, 108-109; provisions for, in Act of $1910,36,41-45$.

Keene, C. B., Director of Division of Postal Savings, cited, 57-58, 78-79, 97, 113.

Limitations on size of postal savings deposits, arguments against, 
88-91 ; arguments favoring, 91-95; bill to modify, passed in 1916, $96,114-116$; bill to modify, vetoed in 1914, 86-87, 113-115; in Act of 1910, 24-25.

Lodge, Senator H. C., views of, on limitations on size of deposits, 91-92.

Losses of postal savings depositors through regulations relating to interest paid, 102-104.

Meyer, G. von L., Postmaster-General, cited, 7.

Minors, as depositors in postal savings offices, 62-65, 92-93.

Money orders, as means of securing savings, 19-20, 79.

Moon bill, passage of, in 1916, 96, 114-116; veto of, in 1914, 8687, 113-115.

Municipal bonds, as security for deposits of postal savings funds, 122-124.

Mutual savings banks, reserves of, 27-28; should be made depository banks, 130-131.

National banks, bonds owned by, as affected by postal savings system, '48-49.

Nativity of depositors in postal savings offices, 57-62; table showing, 59 .

Negro depositors in postal savings offices, 65-66.

Non-interest bearing postal savings deposits, bill providing for, passed in 1916, 96-97, 114-116; bill providing for, vetoed in 1914, 86-87, 113-115; failure to utilize provision for, 97-98.

Out of town depository banks, regulations relating to, 119-120.

Panic of 1907, relation of, to movement for postal savings, 2-4, 17 . Philippine postal savings system, 2 ; text of act establishing, 151167 ; text of amendment to act establishing, 168-169.

Political parties, platforms of, indorsing postal savings system, 4-6.

Postal Savings Bank Act, passage of, 1, 21; provisions of, 21 et seq.; text of, 134-143; text of amendments to, 143-150.

Postal savings bonds, merits of provisions for, 46-48; object in issuing, 126-127; provisions for, 45-46; purchase of, by Board of Trustees, 107-109, 127; report concerning price of, 127.

Postal savings stamps, 25.

Postal savings system, administrative organization of, 21-24, 5052 ; as competitor of banks, 12-16, 76-79; definition of, 6 ; established in $U$. S. in 1910, 1, 21; expenses of, 90-91; Hawaiian, 2; Philippine, 2; profits from operation of, 90-91, 104; text of act establishing, 134-150.

Postmaster-General, cited, 89; powers of, as member of Board of Trustees, 22-24; powers of, enlarged in 1911, 50.

Postmasters, compensation of, in postal savings operations, 5354 ; duties of, in postal savings operations, 26-27, 29-30, 56-57, 113, 117-120; emergency credits of, 26-27, 116-119. 
President of U. S., powers of, under Act of 1910, 43-44, 108-109. Private banks, as depository banks, 110-111.

Profits, of depository banks from deposits of postal savings funds, 125-126; of Government from operation of postal savings system, 90-91, 104.

Rayner, Senator I., mentioned, 37.

Reserve against postal savings deposits, 26-28, 107, 116-119.

Reserves of mutual savings banks, 27-28.

Residence, change of, in relation to interest on postal savings deposits, 101, 104-105.

Robinson, E. L., cited, 77.

Root, Senator E., cited, 41-42.

Runs on commercial banks, as affected by postal savings system, 80-84; instances of, in 1913, 83-84.

Savings banks, facilities of, 6-9; facilities of, compared with postal facilities, 9-12 ; limitations of, on size of deposits, 89; number of, qualified as depository banks, 111; regulations relating to, as depository banks, 130-131.

Secretary of Board of Trustees, provision for, in 1913, 51-52.

Secretary of the Treasury, as member of Board of Trustees, 22-24.

Security for deposits of postal savings funds, provisions for, in Act of 1910, 36, 44, 107, 120; types of bonds acceptable for, 120-124.

Smoot amendment to postal savings bill, 40-42.

Smoot, Senator R., cited, 93.

Solicitor of the Post Office Department, duty of, to pass on security offered by depository banks, 121-122.

Sources of postal savings deposits, 19-20, 75-79, 88.

Sprague, O. M. W., cited, 3.

Stafford, Rep. W. H., cited, 53.

State banks, as depository banks under Act of 1910, 87, 106-111; disqualified as depository banks by Federal Reserve Act, 112113; made depository banks by bill vetoed in 1914, 113-114; made depository banks to limited extent in 1916, 115-116.

State bonds, as security for deposits of postal savings funds, 122-124.

States, distribution of postal savings deposits by, 67-72.

Steenerson, Rep. H., cited, 92.

Sutherland, Senator G., cited, 37-38.

Taft, President W. H., attitude of, toward postal savings, 5-6.

Taxation, exemption of postal savings deposits from, 93-94.

Temporary securities, not acceptablc as security for deposits of postal savings funds, 121.

Third Assistant Postmaster-General, made Secretary of Board of Trustees and placed in charge of Division of Postal Savings, 51-52. 


\section{INDEX}

Time required before postal savings deposits may draw interest, 100-101.

United States bonds, as security for deposits of postal savings funds, 120-125; owned by national banks, as affected by postal savings system, 48-49; provisions for investment of postal savings funds in, 41-45, 48-49, 106-109; purchase of, by Board of Trustees, 107-109, 127.

United States Postal Savings Act and amendments, text of, 134150.

Weed, T. L., Director of Division of Postal Savings, cited, 89$90,110$.

Weeks, Senator J. W., cited, 91, 95.

Wilson, President Woodrow, vetoes Moon bill, 87, 95-96, 114-115.

Withdrawal of postal savings deposits, 25-26, 101-104. 
0
4

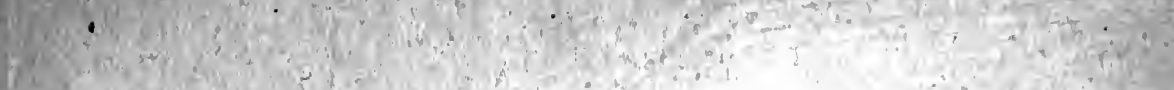

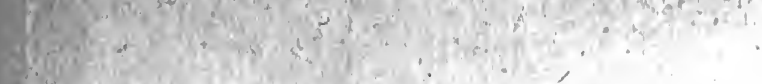

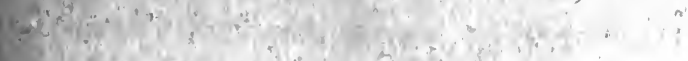

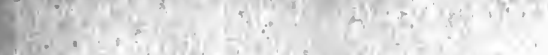

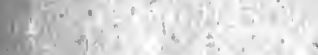

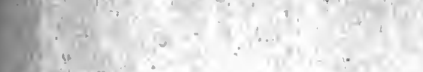

(1)

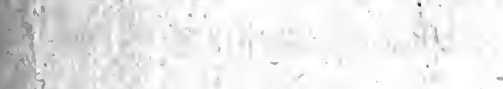
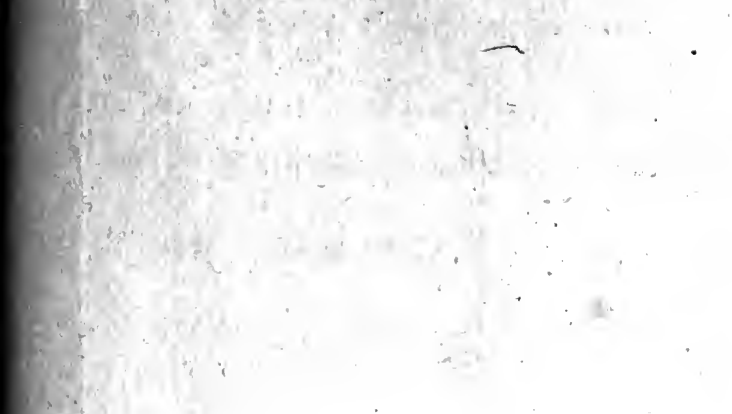



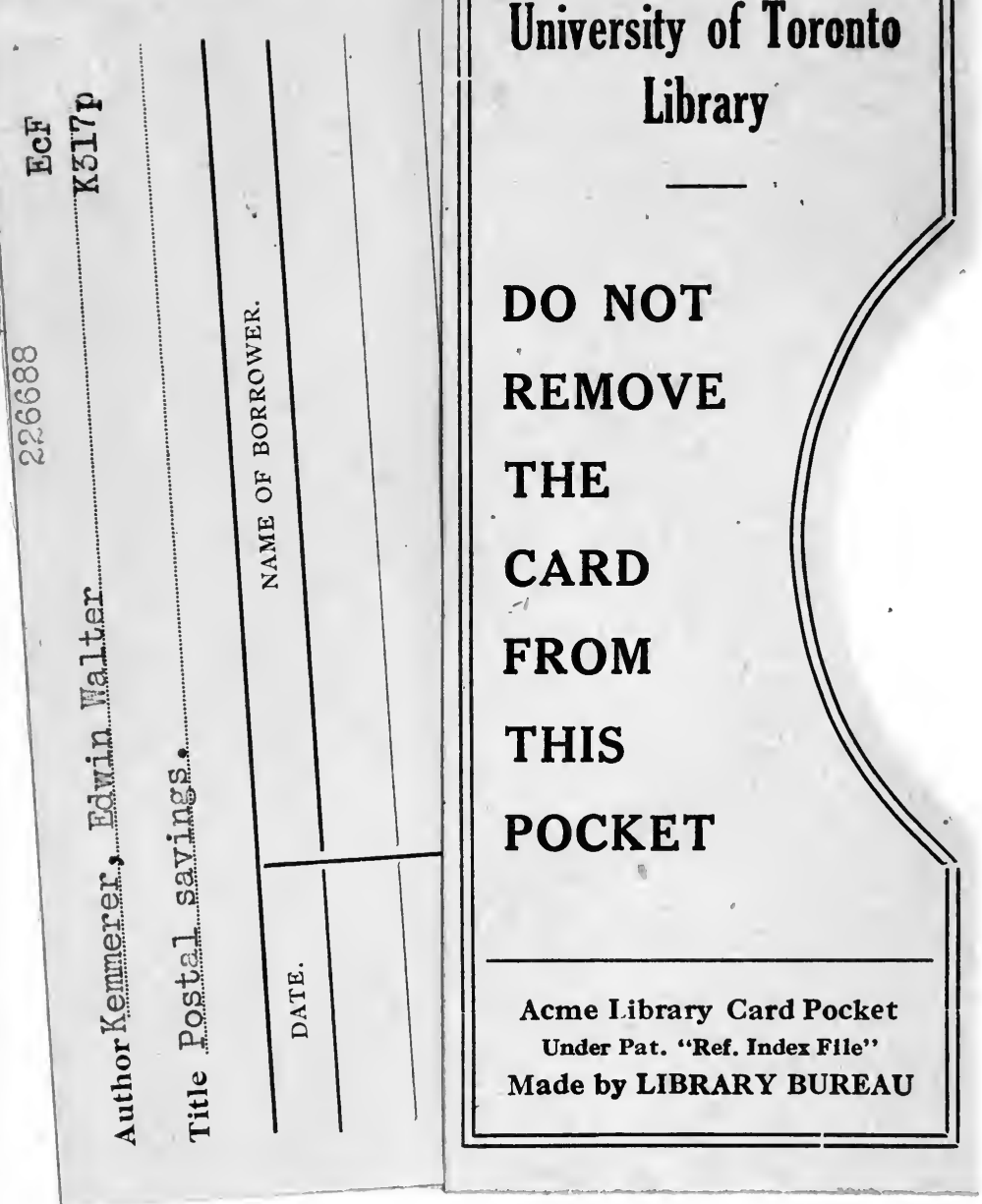


